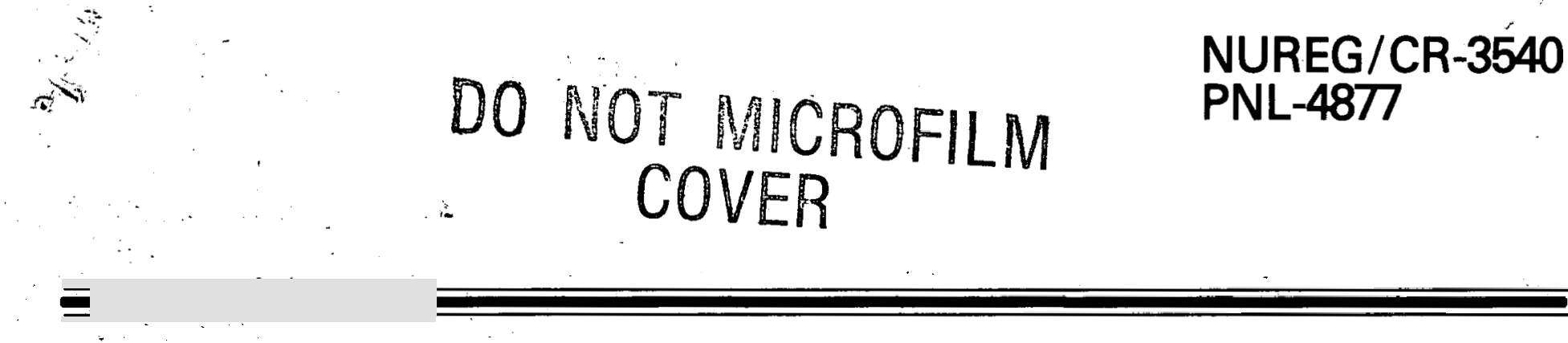

\title{
Radiological Assessment of Steam Generator Repair and Replacement
}

Prepared by M. A. Parkhurst, L. A. Rathbun/PNL

D. W. Murphy/REECo

Pacific Northwest Laboratory

Operated by

Battelle Memorial Institute

Prepared for

U.S. Nuclear Regulatory

Commission

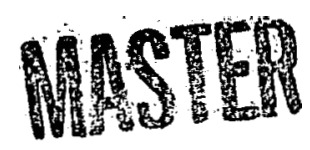




\section{DISCLAIMER}

This report was prepared as an account of work sponsored by an agency of the United States Government. Neither the United States Government nor any agency Thereof, nor any of their employees, makes any warranty, express or implied, or assumes any legal liability or responsibility for the accuracy, completeness, or usefulness of any information, apparatus, product, or process disclosed, or represents that its use would not infringe privately owned rights. Reference herein to any specific commercial product, process, or service by trade name, trademark, manufacturer, or otherwise does not necessarily constitute or imply its endorsement, recommendation, or favoring by the United States Government or any agency thereof. The views and opinions of authors expressed herein do not necessarily state or reflect those of the United States Government or any agency thereof. 


\section{DISCLAIMER}

Portions of this document may be illegible in electronic image products. Images are produced from the best available original document. 
This report was prepared as an account of work sponsored by an agency of the United States Government. Neither the United States Government nor any agency thereof, or any of their employees, makes any warranty, expressed or implied, or assumes any legal liability of responsibility for any third party's use, or the results of such use, of any information, apparatus, product or process disclosed in this report, or represents that its use by such third party would not infringe privately owned rights.

\section{Availability of Reference Materials Cited in NRC Publications}

Most documents cited in NRC publications will be available from one of the following sources:

1. The NRC Public Document Room, 1717 H Street, N.W. Washington, DC 20555

2. The NRC/GPO Sales Program, U.S. Nuclear Regulatory Commission, Washington, DC 20555

3. The National Technical Information Service, Springfield, VA 22161

Although the listing that follows represents the majority of documents cited in NRC publications, it is not intended to be exhaustive.

Referenced documents available for inspection and copying for a fee from the NRC Public Document Room include NRC correspondence and irternal NRC memoranda; NRC Office of Inspection and Enforcement bulletins, circulars, information notices, inspection and investigation notices; Licensee Event Reports; vendor reports and correspondence; Commission papers; and applicant and licensee documents and correspondence.

The following documents in the NUREG series are available for purchase from the NRC/GPO Sales Program: formal NRC staff and contractor reports, NRC-sponsored conference proceedings, and NRC booklets and brochures. Also available: are Regulatory Guides, NRC regulations in the Code of Federal Regulations, and Nuclear Regulatory Commission /ssuances.

Documents available from the National Technical Information Service include NUREG series reports and technical reports prepared by other federal agencies and reports prepared by the Atomic Energy Commission, forerunner agency to the Nuclear Regulatory Commission.

Documents available from public and special technical libraries include all open literature iterns, such as books, journal and periodical articles, and transactions. Federal Register notices, federal and state legislation, and congressional reports can usually be obtained from these libraries.

Documents such as theses, dissertations, foreign reports and translations, and non-NRC conference proceedings are available for purchase from the organization sponsoring the publication cited.

Single copies of NRC draft reports are available free upon written request to the Division of Technical Information and Document Control, U.S. Nuclear Regulatory Commission. Washington, DC 20555.

Copies of industry codes and standards used in a substantive manner in the NRC regulatory process are maintained at the NRC Library, 7920 Norfolk Avenue, Bethesda, Maryland, and are available there for reference use by the public. Codes and standards are usually copyrighted and may be purchased from the originating organization or, if they are American National Standards, from the American National Standards Institute, 1430 Broadway, New York, NY 10018. 


\section{Radiological Assessment of Steam Generator Repair and Replacement}

Manuscript Completed: November 1983

Date Published: December 1983

Prepared by

M. A. Parkhurst, L. A. Rathbun, Pacific Northwest Laboratory

D. W. Murphy, REECo

Pacific Northwest Laboratory

Fichland, WA 99352

\section{Prepared for \\ Division of Systems Integration \\ Office of Nuclear Reactor Regulation \\ U.S. Nuclear Regulatory Commission \\ Washington, D.C. 20555 \\ NRC FIN B2522}

\section{DISCLAIMER}

This report was prepared as an account of work sponsored by an agency of the United States Government. Neither the United States Government nor any agency thereof, nor any of their employees, makes any warranty, express or implied, or assumes any legal liability or responsibility for the accuracy, completeness, or usefulness of any information, apparatus, product, or process disclosed, or represents that its use would not infringe privately owned rights. Reference herein to any specific commercial product, process, or service by trade name, trademark, manufacturer, or otherwise does not necessarily constitute or imply its endorsement, recommendation, or favoring by the United States Government or any agency thereof. The views and opinions of authors expressed herein do not necessarily state or reflect those of the United States Government or any agency thereof.

This document is PUBLICLY RELEASABLE Bang steel Authorizing Official 


\section{NOTICE}

This report was prepared as an account of work sponsored by an agency of the United States Government. Neither the United States Government nor any agency thereof, or any of their employees, makes any warranty, expressed or implied, or assumes any legal liability of responsibility for any third party's use, or the results of such use, of any information, apparatus. product or process disclosed in this report, or represents that its use by such third party would not infringe privately owned rights.

\section{Availability of Reference Materials Cited in NRC Publications}

Most documents cited in NRC publications will be available from one of the following sources:

1. The NRC Public Document Room, 1717 H Street, N.W. Washington, DC 20555

2. The NRC/GPO Sales Program, U.S. Nuclear Regulatory Commission, Washington, DC 20555

3. The National Technical Information Service, Springfield, .VA 22161

Although the listing that follows represents the majority of documents cited in NRC publications, it is not intended to be exhaustive.

Referenced documents available for inspection and copying for a fee from the NRC'Public Document Room include NRC correspondence and iriternal NRC imemoranda: NRC Office of Inspection and Enforcement bulletins, circulars, information notices, inspection and investigation notices; Licensee Event Reports; vendor reports and correspondence; Commission papers; and applicant and licensee documents and correspondence.

The following documents in the NUREG series are available for purchase from the NRC/GPO Sales Program: formal NRC staff and contractor reports, NRC.sponsored conference proceedings, and NRC booklets and brochures. Also available are Regulatory Guides, NRC regulations in the Code of Federal Regulations, and Nuclear Regulatory Commission Issuances.

Documents available from the National Technical Information Service include NUREG series reports and technical reports prepared by other federal agencies and reports prepared by the Atomic Energy Commission, forerunner agency to the Nuclear Regulatory Commission.

Documents available from public and special technical libraries include all open literature items, such as books, journal and periodical articles, and transactions. Federal Register notices, federal and state legislation, and congressional reports can usually be obtained from these libraries.

Documents such as theses, dissertations, foreign reports and translations, and non-NRC conference proceedings are available for purchase trom the organization sponsoring the publication cited.

Single copies of NRC draft reports are available free upon written request to the Division of Tech. nical Information and Document Control, U.S. Nuclear Regulatory Commission, Washington, DC 20555.

Copies of industry codes and standards used in a substantive manner in the NRC regulatory process are maintained at the NRC Library, 7920 Norfolk Avenue, Bethesda, Maryland, and are available there for reference use by the public. Codes and standards are usually copyrighted and may be purchased from the originating organization or, if they are American National Standards, from the American National Standards Institute, 1430 Broadway. New York. NY 10018. 
$\overline{10}-$

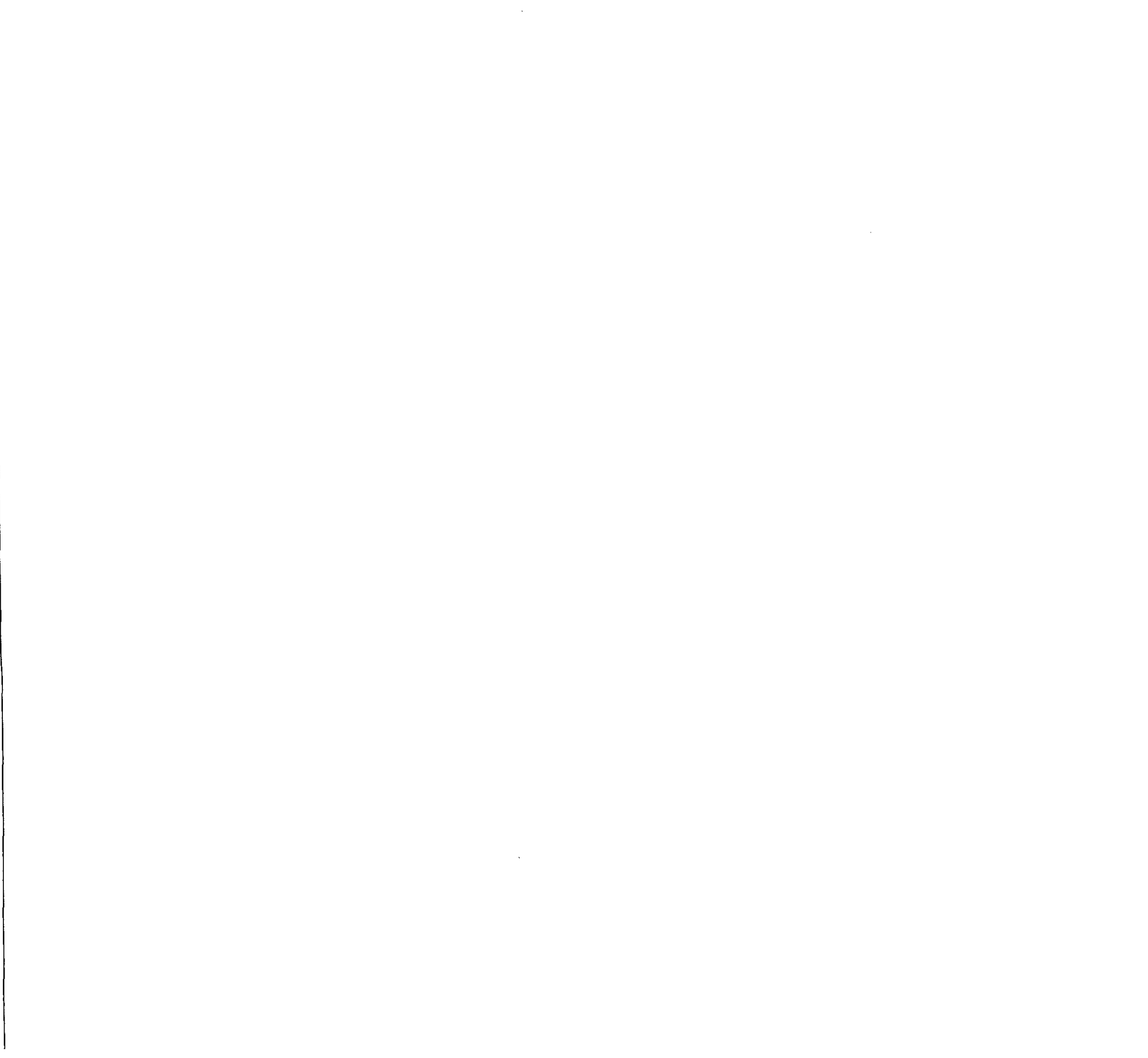


Previous analyses of the radiological impact of removing and replacing corroded steam generators have been updated based on experience at Surry Units 1 and 2 and Turkey Point Units 3 and 4 . The sleeving repairs of degraded tubes at San Onofre Unit 1, Point Beach Unit 2, and R. E. Ginna are also analyzed. Actual occupational doses incurred during application of the various technologies used in repairs have been included, along with radioactive waste quantities and constituents. Considerable progress has been made in improving radiation protection and reducing worker dose by the development of remotely controlled equipment and the implementation of dose reduction strategies that have been successful in previous repair operations. 
TT. 
Steam generators in pressurized-water-reactor generating stations around the U.S. have experienced a variety of tube degradation problems that eventually cause loss of tube integrity. The degradation has largely been due to corrosion, sludge buildup, vibration and wear, and damage by foreign objects. When the damage is serious enough that a tube is breached or its structural integrity is questioned, the tube is usually plugged to prevent leakage. The plugging of a large number of tubes results in a loss of heat exchanger efficiency and can lead to the derating of the unit. In addition, the frequent inspecting and plugging of tubes involve significant occupational dose.

Although a number of utilities have repaired or are planning to repair steam generators in the near future, this action is by no means routine. Repairs so far have included replacing the lower shell, including the tube bundle and channel head; replacing the lower shell without replacing the channel head; and sleeving the defective tubes to keep them in service.

Steam generator decontamination, replacement, and sleeving are undergoing rapid technological development, and the decision to undertake major repairs requires consideration of the available repair technologies for the type of tube degradation in question and of plant-specific factors. The long-term benefits of sleeving or replacement versus the economic and exposure costs of the repairs must be evaluated.

Each completed repair project adds to the accumulated experience and to an understanding of ways to reduce the labor needed for and the occupational dose resulting from these activities. This information needs to be available to the U.S. Nuclear Regulatory Commission's inspectors and licensees to assure that future repairs make use of past experience.

This study focuses on the repairs made at five nuclear plants. Its specific purpose is to look at the strategies used to keep doses as low as is reasonably achievable, the techniques for monitoring exposures, the radiation doses to workers, the methods used to handle radioactive waste, and the accumulated experience applicable to future steam generator repairs. Data presented include occupational doses for the repairs as measured by dosimeters, doses on a task-by-task basis (where these data are available), and the volume of radioactive waste generated. Some of the significant lessons learned through accumulated experience are highlighted. 
$\overline{1 .}$ 


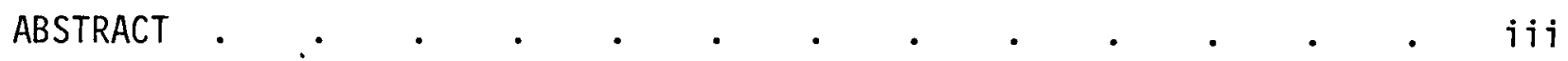

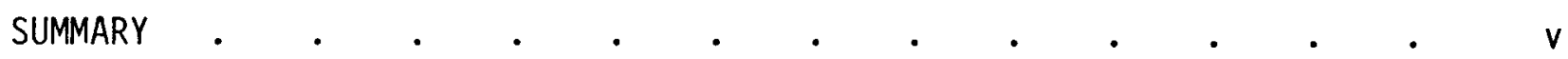

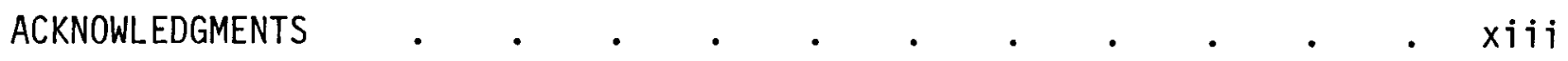

1.0 INTRODUCTION

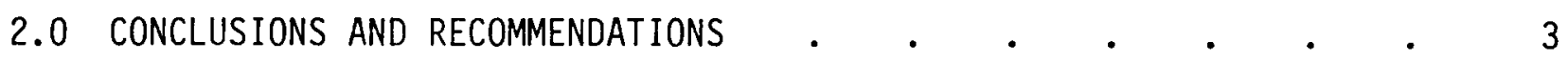

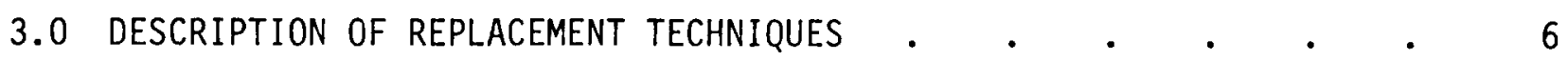

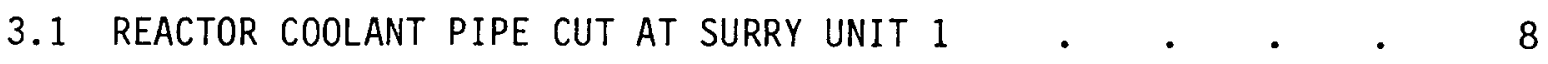

3.1.1 Preparations for Steam Generator Removal . . . 9

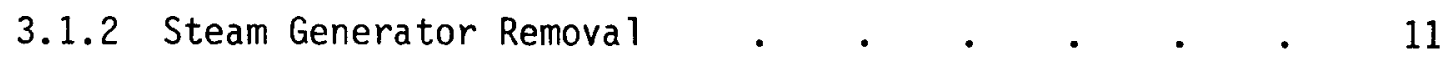

3.1.3 Installation of Replacement Generator . . . . . 11

3.2 CHANNEL HEAD CUT AT TURKEY POINT UNITS 3 AND 4 • 41

3.2.1 Preparations for Steam Generator Removal . . . 13

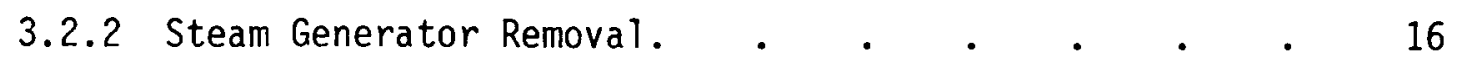

3.2.3 Installation of Replacement Generator . . . . . 17

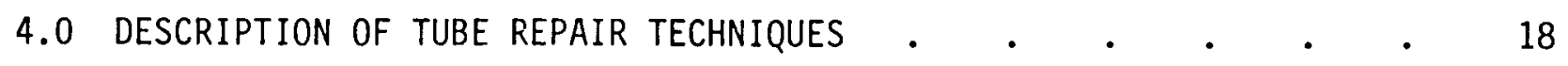

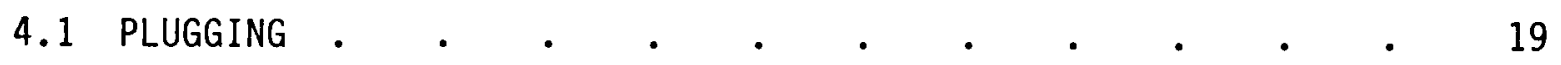

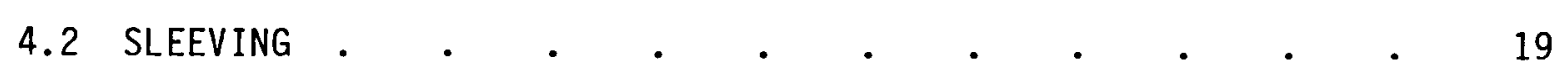

4.2.1 Sleeving Using Hydraulic Expansion and a Rolled Seal . 20

4.2.2 Sleeving Using Explosive Expansion and a Brazed Seal • 23

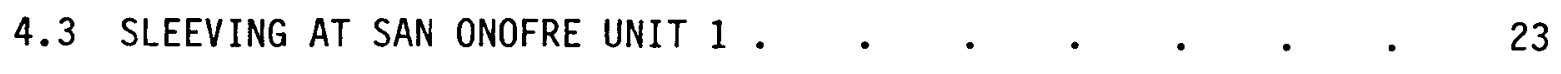

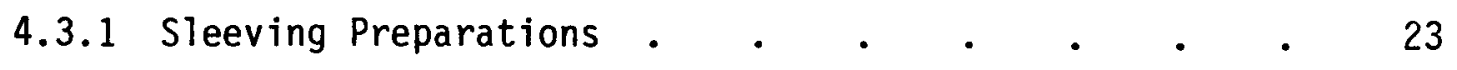

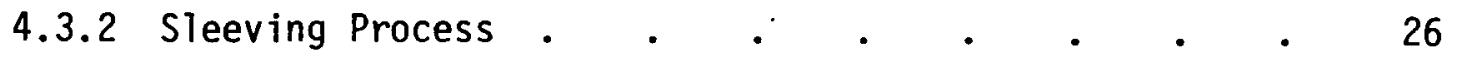

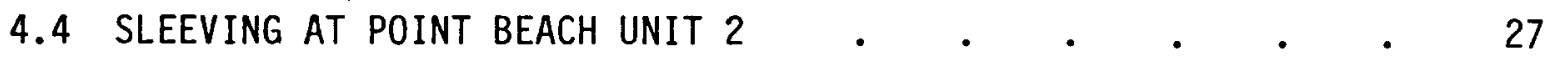

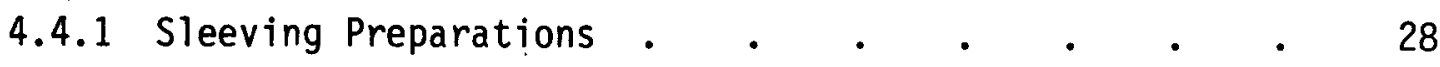




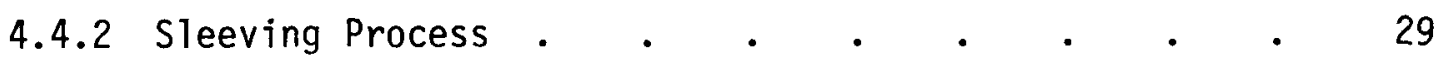

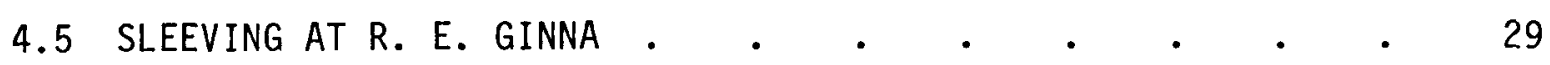

4.5.1 Shielding Preparations . . . . . . . . . 30

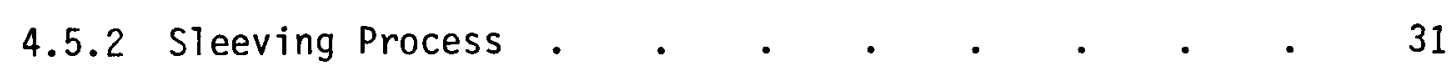

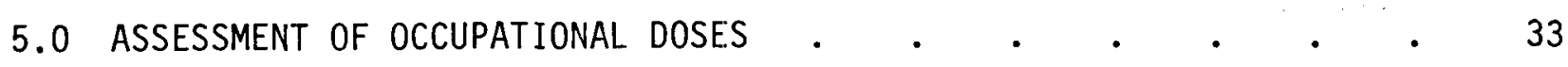

5.1 STRATEGIES FOR KEEPING DOSES ALARA . . . . . . . . 33

5.1 .1 Surry Unit 1 . $\quad . \quad$. $\quad . \quad$. $\quad . \quad$. $\quad . \quad$. 34

5.1 .2 Turkey Point Units 3 and 4 . $\quad . \quad$. $\quad . \quad$. $\quad 35$

5.1.3 San Onofre Unit 1 . $\quad . \quad$. $\quad . \quad$. $\quad . \quad 36$

5.1 .4 Point Beach Unit 2 . $\quad . \quad$. $\quad . \quad$. 37

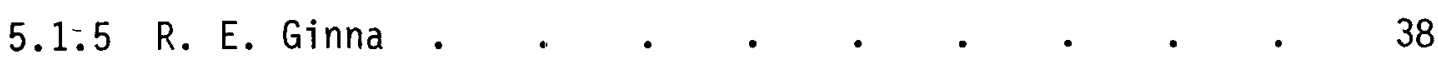

5.1.6 Developments in Remote Tooling and Robotics . . 39

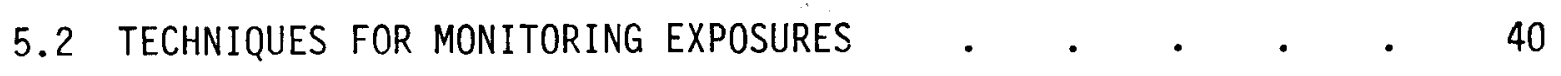

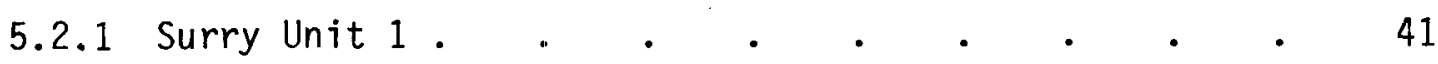

5.2.2 Turkey Point Units 3 and 4 . $4 . \quad . \quad . \quad . \quad . \quad 41$

5.2.3 San Onofre Unit 1 . . . . . . . . . 42

5.2 .4 Point Beach Unit 2 . $\quad . \quad$. . . . 42

5.2 .5 R. E. Ginna . . . . . . . . . . . . 43

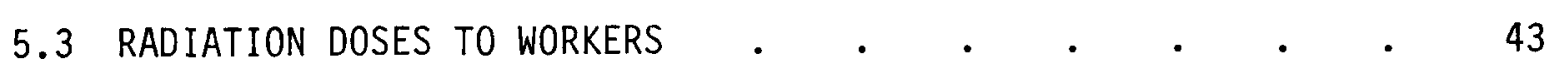

5.3 .1 Surry Unit 1 . $\quad . \quad$. $\quad . \quad$. $\quad . \quad$. 44

5.3.2 Turkey Point Units 3 and 4 . $\quad . \quad$. . . 45

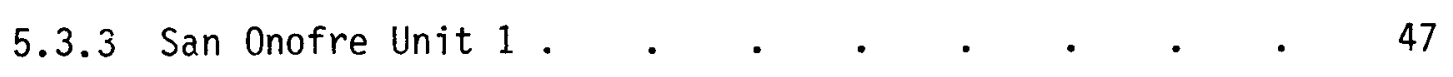

5.3 .4 Point Beach Unit 2 . $2 . \quad . \quad . \quad . \quad . \quad . \quad 49$

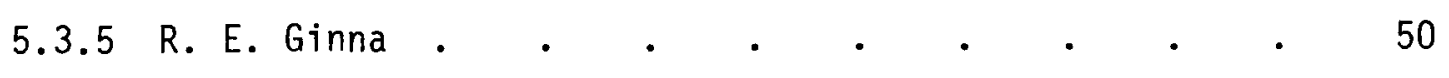

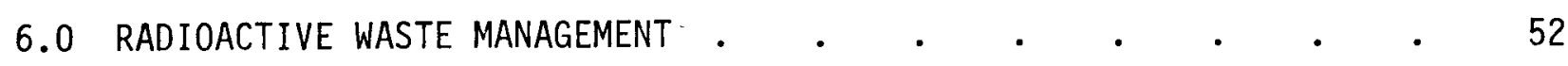

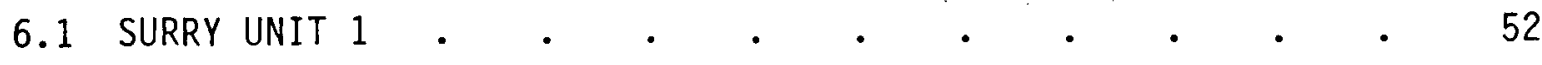


6.2 TURKEY POINT UNITS 3 AND $4 \quad$. 4 .

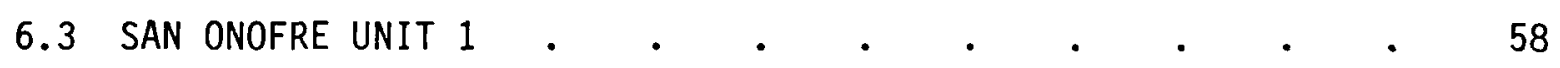

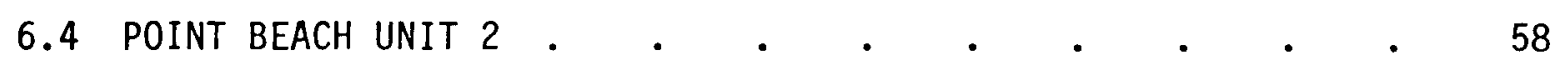

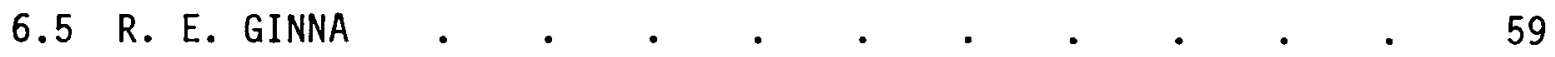

7.0 ACCUMULATED EXPERIENCE FOR FUTURE APPLICATION . • • • • • 60

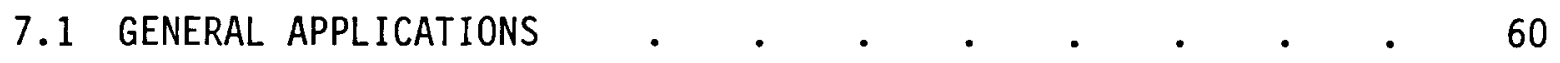

7.2 REPLACEMENT APPLICATIONS •

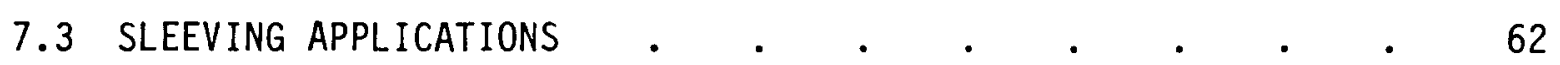

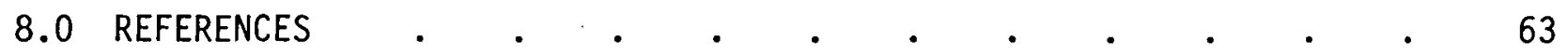

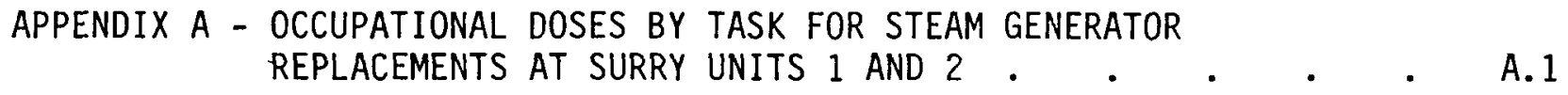

$\begin{aligned} \text { APPENDIX B - } & \text { OCCUPATIONAL DOSES BY TASK FOR STEAM GENERATOR } \\ & \text { REPLACEMENTS AT TURKEY POINT UNITS } 3 \text { AND } 4 \text { • } ~ • ~\end{aligned}$ 


\section{FIGURES}

1 Structure of a Generic Recirculating Steam Generator . . . 7

2 Location of Pipe Cuts for Surry Steam Generator Replacements - 9

3 A Cross-Section View of the Turkey Point Steam Generator Showing

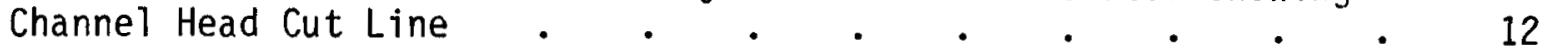

4 A Tube Sleeve Hydraulically Expanded and Roll Sealed at the Upper and Lower Joints . . . . . . . . . 21

5 A Tube STeeve Explosively Expanded and Sealed at the Upper and Lower Joints with a Braze and an Explosive Weld . $\quad$ - $\quad 22$ 
1 Steam Generator Lower Assembly Replacements . . . . . 4

2 Steam Generator Tube Sleeving Repairs . . . . . . . 4

3 Summary of Labor and Occupational Doses Associated with

Steam Generator Replacement at Surry Units 1 and 2 . . . 44

4 Summary of Labor and Occupational Doses Associated with

Steam Generator Replacement at Turkey Point Units 3 and 4 . . 46

5 Summary of Occupational Doses Associated with Sleeving

Activities at San Onofre Unit 1 . $\quad$ • . . . . . . 48

6 Summary of Occupational Doses Associated with Sleeving Activities at Point Beach Unit $2 . \quad . \quad . \quad . \quad . \quad . \quad . \quad$.

7 Summary of Occupational Doses Associated with Sleeving

Activities at R. E. Ginna . . . . . . . . 50

8 Comparison of Total Amounts of Solid, Liquid, and Gaseous

Wastes from Replacement Activities at Surry Units 1 and 2 . $\quad 53$

9 Isotopic Distribution of Liquid Effluents Released from

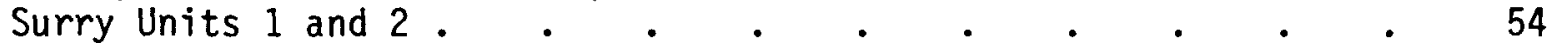

10 Isotopic Distribution of Gaseous Effluents Released from

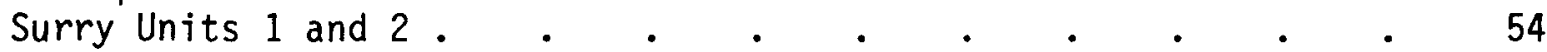

11 Solid Low-Level Radioactive Waste Generated and Shipped

from Turkey Point by May 16, 1983 . $\quad$ • . . . . . 56

12 Isotopic Distribution of Liquid Effluents Released During

Steam Generator Replacement at Turkey Point Units 3 and 4 . $\quad 56$

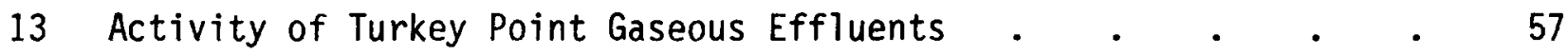

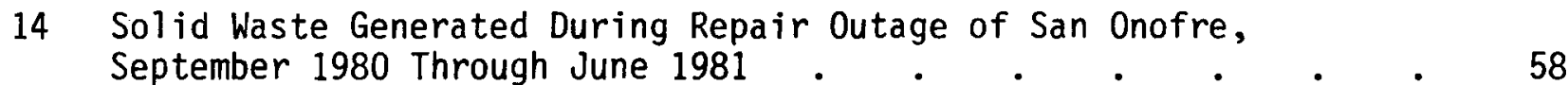




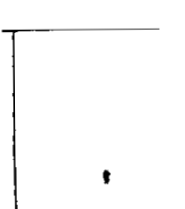




\subsection{INTRODUCTION}

Corrosion problems in the secondary side of steam generators at several nuclear power plants have led to the need for periodic inspection and plugging of the steam generator tubes to ensure continued safe operation of the plants. The inspection and maintenance outages and lower heat transfer efficiency resulting from the plugging have lowered power output from the affected plants. Efforts to inspect and repair steam generators to maintain appropriate safety margins have caused such severe economic and occupational-dose problems that some utilities have chosen to replace entire steam generators or portions of them. The removal, replacement, and refurbishment of steam generators present a complex radiological and engineering problem.

The evaluation of alternatives for steam generator maintenance must involve consideration of all related costs. Radiological costs of considerable importance are 1 ) the occupational radiation dose and 2) the radioactive effluents (i.e., gaseous, liquid, and solid wastes) resulting from the maintenance activities. While long-term savings may result from the replacement of steam generators, the potentially high occupational radiation dose and the quantity of radioactive effluents involved must be controlled during replacement activities.

This report is the third in a series funded by the U.S. Nuclear Regulatory Commission (NRC) to evaluate the repair and replacement of steam generators. The first document, NUREG/CR-0199, Radiological Assessment of Steam Generator Removal and Replacement, was published in 1978 prior to the removal of the Surry Unit 2 steam generators. The report was updated in 1980 as NUREG/CR-1595, Radiological Assessment of Steam Generator Removal and Replacement: Update and Revision, to include the dose estimates from Surry Unit 2 and the removal experience that had been gained through most of 1980 . Additional topics in the 1980 report included steam generator decontamination, disposal, and in-place retubing.

Since the 1980 report was published, steam generator replacements at Surry Unit 1 and Turkey Point have been completed. Replacements are also planned or underway at Point Beach Unit 1 and $H$. B. Robinson Unit 2. In addition, advances in technology have made large-scale sleeving a viable alternative to the replacement of tube bundles for certain types of damage: sleeving can be used to return plugged tubes to service if their damaged sections are within or near the tubesheet. San Onofre Unit 1, Point Beach Unit 2, Indian Point Unit 3, R. E. Ginna, and Millstone Unit 2 are some of the plants at which extensive sleeving has recently been performed.

This report analyzes the repair projects at five nuclear power plants and focuses particularly on the dose reduction strategies used, the techniques for monitoring of exposures, the occupational doses incurred, the management of radioactive waste, and specific recommendations for similar future projects. The scope of this study includes the steam generator repair projects carried out at Surry Unit 1, operated by Virginia Electric and Power Company (VEPCO); Turkey Point Units 3 and 4, operated by Florida Power and Light Company (FP\&L); San Onofre Unit 1, owned by Southern California Edison Co. (SCE); 
Point Beach Unit 2, a part of Wisconsin Electric Power Co. (WEPCO); and R. E. Ginna, a one-unit plant owned by Rochester Gas and Electric Company (RG\&E). These five plants all have Westinghouse U-tube type steam generators. A.11 also began commercial operation in the late 1960s or early 1970s using phosphate secondary-water-control chemistry, which was later identified as a source of tube degradation.

The background of the tube degradation problem and the replacement or sleeving operations undertaken at each site are briefly described. Techniques for monitoring worker exposure are discussed, and summaries or task breakdowns of occupational doses from the repair operations are given.

General dose reduction strategies for any type of major steam generator repair, as well as the specific dose reduction strategies for particular repair techniques, are important for consideration in future repair projects. The general strategies (presented here) include careful planning and preparation, good worker training programs, shielding, decontamination, and the use of remote tooling. Additional practical and innovative ideas developed for keeping doses as $10 \mathrm{w}$ as is reasonably achievable (ALARA) are offered, with recommendations for their use. Listings of the volumes and isotopic distributions of liquid and airborne releases of effluents are included where such information was available, and the volume and main constituents of solid wastes generated are also listed.

Although the focus of this report is on repairs of recirculating-water steam generators in pressurized water reactors (PWRs), many of the techniques reviewed may be applicable to other steam generators and other highly contaminated reactor components. 


\subsection{CONCLUSIONS AND RECOMMENDATIONS}

A number of technologies for steam generator repair have been developed, and the method selected depends mainly on the type, extent, and location of tube and support plate damage. Replacement of the lower assembly is an option when denting or other serious damage is extensive. Sleeving has been used mostly to repair tubes displaying intergranular attack near the tubesheet. Retubing has not been commercially attempted but may be useful in replacing badly degraded tube bundles. Tube plugging will continue to be performed and the use of removable plugs allows the later option of sleeving to return tubes with certain types of damage to service.

The technique for replacing lower assemblies has been made increasingly time- and exposure-efficient through experience and the use of improved methods and remotely controlled tooling. The approximate outage duration and the resulting dose are shown in Table 1 . Although the Turkey Point Unit 3 dose was higher than the Surry doses, the general trend is toward reduction of both time and occupational dose. Future replacements are expected to require even shorter outage times. The staff at Point Beach Unit 1 anticipate that the time from defueling to refueling will be about 180 days (Nucleonics Week 1983).

The sleeving technique has also progressed since the first large-scale sleeving at San Onofre, which was a developmental effort. The approximate duration for sleeving operations and the resulting dose are given in Table 2 . The greatly reduced exposure of the Point Beach sleeving versus the San Onofre sleeving reflects improvements made in the channel head decontamination and sleeving technique, additional planning and preparation, and fewer problems with the process. The sleeving program at Ginna used a different sleeving technique. Plans to sleeve additional tubes during the Ginna outage were deferred pending an NRC decision on preventative sleeving.

High-dose activities associated with steam generator repairs are generally those performed in the vicinity of the reactor coolant piping or the steam generator channel head. Four approaches have been used to reduce the dose to workers in and around the channel head. First, lead and water shielding has been used to reduce radiation fields. Second, some form of channel head decontamination has been used. Chemical decontamination techniques and grit blast methods using magnetite, alumina, or boric oxide grit have shown varying efficiencies in reducing dose rates and surface contamination. All are potentially able to reduce dose rates by at least a factor of 2 . Third, extensive worker training has better prepared workers to reduce the time that they are exposed. And finally, computer-controlled manipulators and other remote tooling have been developed to reduce the need for entries into the channel head.

Large quantities of low-level solid waste have been generated in previous repair efforts. However, some strategies can be used to reduce this waste generation: the amount of material entering containment can be significantly reduced by unpacking materials in clean areas and keeping shipping containers 
TABLE 1. Steam Generator Lower Assembly Replacements

\begin{tabular}{|c|c|c|c|c|c|c|c|}
\hline Replacements & MWe & $\begin{array}{l}\text { Primary } \\
\text { Loops } \\
\end{array}$ & Outage Dates & $\begin{array}{c}\text { Duration } \\
\text { (mo) }\end{array}$ & $\begin{array}{c}\text { Occu } \\
\text { Total(a) } \\
\text { (man-rem) } \\
\end{array}$ & $\begin{array}{l}\text { ional Dose } \\
\text { Decontamination } \\
\text { Task (man-rem) }\end{array}$ & $\begin{array}{l}\text { Volume of Solid } \\
\text { Rad Waste }\left(\mathrm{ft}^{3}\right) \\
\end{array}$ \\
\hline Surry 2 & 824 & 3 & $2 / 79-12 / 79$ & 10 & 2141 & -- & 57,790 \\
\hline Surry 1 & 824 & 3 & $9 / 80-7 / 81$ & 9.5 & 1759 & -- & 67,580 \\
\hline Turkey Point 3 & 728 & 3 & $6 / 81-4 / 82$ & 9.5 & 2151 & 155 & 31,348 \\
\hline Turkey Point 4 & 728 & 3 & $10 / 82-5 / 83$ & 7 & 1305 & 91 & 33,881 \\
\hline
\end{tabular}

(a) Includes all dose for the outage some of which may not have been related to steam generator activities.

TABLE 2. Steam Generator Tube Sleeving Repairs

\begin{tabular}{|c|c|c|c|c|c|c|c|c|c|}
\hline $\begin{array}{l}\text { Sleeving } \\
\text { Projects }\end{array}$ & MWe & $\begin{array}{l}\text { Primary } \\
\text { Loops } \\
\end{array}$ & $\begin{array}{l}\text { Outage } \\
\text { Dates }\end{array}$ & $\begin{array}{c}\text { Duration } \\
\text { (mo) }\end{array}$ & $\begin{array}{c}\text { Number of } \\
\text { Tubes } \\
\text { Sleeved } \\
\end{array}$ & $\begin{array}{l}\text { 0ccupat } \\
\text { Tota!(a). } \\
\text { (man-rem) }\end{array}$ & $\begin{array}{l}\text { ional Dose } \\
\text { Decontamination } \\
\text { Task (man-rem) } \\
\end{array}$ & $\begin{array}{c}\text { Tube } \\
\text { Sleeving } \\
\text { Tasks } \\
\end{array}$ & $\begin{array}{l}\text { Volume of } \\
\text { Sol id Rad } \\
\text { Waste } \\
\left(\mathrm{ft}^{3}\right) \\
\end{array}$ \\
\hline San Onofre 1 & 456 & 3 & $9 / 80-6 / 81$ & $10^{(b)}$ & 6900 & 3493 & 173 & 3055 & 43,082 \\
\hline Point Beach 2 & 524 & 2 & $4 / 83-6 / 83$ & 2 & 3000 & 525 & $44^{(c)}$ & $445^{(c)}$ & 4,790 \\
\hline R. E. Ginna & 496 & 2 & $4 / 83-6 / 83$ & 2 & 79 & 471 & 136 & 130 & 5,473 \\
\hline
\end{tabular}

(a) Includes all dose for the outage some of which may not have been related to steam generator activities.

(b) Outage began in April 1980 for maintenance and refueling. The discovery of tube damage lead to initiation of

(c) Number shown is based on vendor's task accounting and is slightly different than utilities'accounting. 
outside containment; tools and other equipment and components can be decontaminated; and uncontaminated wastes can be separated from contaminated wastes. The quantities of solid waste generated during sleeving operations are not excessive, and the volume and activities of treated liquid and gaseous effluents are well below effluent limits.

The accumulated experience with steam generator replacements, sleeving operations, and radioactive waste management has led to the identification of numerous effective strategies for dose reduction. Some of the recommendations are highlighted below.

1. Planning plays a key role in the man-hours required for the timely completion of repairs. Management commitment to ALARA principles, and the involvement of the health physics staff, from the early planning stages, help reduce occupational dose.

2. The use of training programs to familiarize workers with the tasks to be performed and with appropriate radiation protection procedures is a highly effective means of improving worker protection and efficiency. Mockup training in circumstances simulating containment and the use of videotapes of previous repair activities are especially beneficial.

3. Audio-visual surveillance has proved very effective for monitoring the quality and progress of repair efforts while reducing the exposure of supervisors, QA personnel, and health physics personnel.

4. Providing rest stations in areas of containment that have low radiation fields reduces the exposure of workers waiting to perform tasks.

5. An initial general cleanup and decontamination of containment, with periodic housekeeping and decontamination of walkways, platforms, tools, and equipment, is highly beneficial in reducing worker skin contamination, airborne activity, and the need for respiratory-protection devices.

6. Systems for tracking occupational dose, particularly real-time computer systems, are extremely helpful in monitoring dose by task and in the early identification of workers approaching their quarterly dose limits.

The occupational doses resulting from future steam generator repairs will be reduced by further developments in decontamination methods (which will reduce channel head dose rates) and in remote equipment (which will reduce the need for channel head entries and manual work inside the channel head). Although the construction of steam generators and the control of secondaryside water chemistry are being improved in an effort to prevent tube damage, the need for tube repairs will continue. Perfecting methodologies for repairing steam generators quickly and with a minimum occupational dose will greatly extend the lifetime service of each unit, reduce worker doses, and conserve licensee resources. 


\subsection{DESCRIPTION OF REPLACEMENT TECHNIQUES}

The replacement of steam generators is a major undertaking from both an engineering and an occupational-dose perspective. The layout inside the containment building and the steam generator support system are critical elements in assessing the most appropriate approach for removing the steam generator and incurring as little occupational dose as possible.

Each of the five sites studied in this project has Westinghouse U-tube, recirculating-water steam generators. The generators are divided into upper and lower assemblies (Figure 1). The upper assembly houses the moistureseparating equipment, and steam passes through it prior to entering the turbine. The lower assembly contains the heat-exchanging tube bundle through which the primary water circulates. The primary water is used to generate steam in the secondary-water coolant system and is cooled in the process. The secondary system is contained within the shell wrapper and circulates outside the tubes. The bowl-shaped channel head is located at the bottom of the lower assembly and is separated from the tube bundle by the tubesheet. A vertical divider plate within the channel head separates the inlet water (circulating from the reactor coolant pipe (RCP) to the steam generator) from the outlet water (circulating from the steam generator back through the RCP to the reactor).

In steam generator replacements to date, only the lower assembly containing the tube bundle (with or without the channel head) has been removed from containment; the upper assembly has been moved only temporarily within containment while parts of the moisture-separating equipment were modified, refurbished, or replaced. The upper and lower assemblies have been separated at the transition cone. The exact location of the cut for this separation is determined by the diameter of the equipment hatch through which the lower assembly is removed from containment, and by the diameter of the moistureseparating equipment; the lower assembly must be able to fit through the equipment hatch, and the moisture-separating equipment must be able to be removed from and then reinstalled in the upper assembly.

The lower assembly has been separated from the reactor coolant system (RCS) using cuts in two locations. The Surry lower assemblies were removed by cutting the RCP, which allowed for the removal of the entire lower assembly. This type of cut does not require channel head entries or channel head decontamination, although pipe decontamination may be necessary. However, much of the cutting and welding is done in high radiation fields attributed mostly to the dose rates in and around the RCP. Realignment of the primary pipes during the installation and postinstallation phases has resulted in significant dose.

For the removal of the lower assemblies at Turkey Point, a cut was made through the channel head and the divider plate just below the tubesheet. This type of cut avoids the dose rates and realignment difficulties attributed to cutting the RCP. However, it requires numerous steam generator entries and is best done following channel head decontamination, a process that may be dose intensive in itself. It also requires exact channel head alignment with the new lower assembly. 


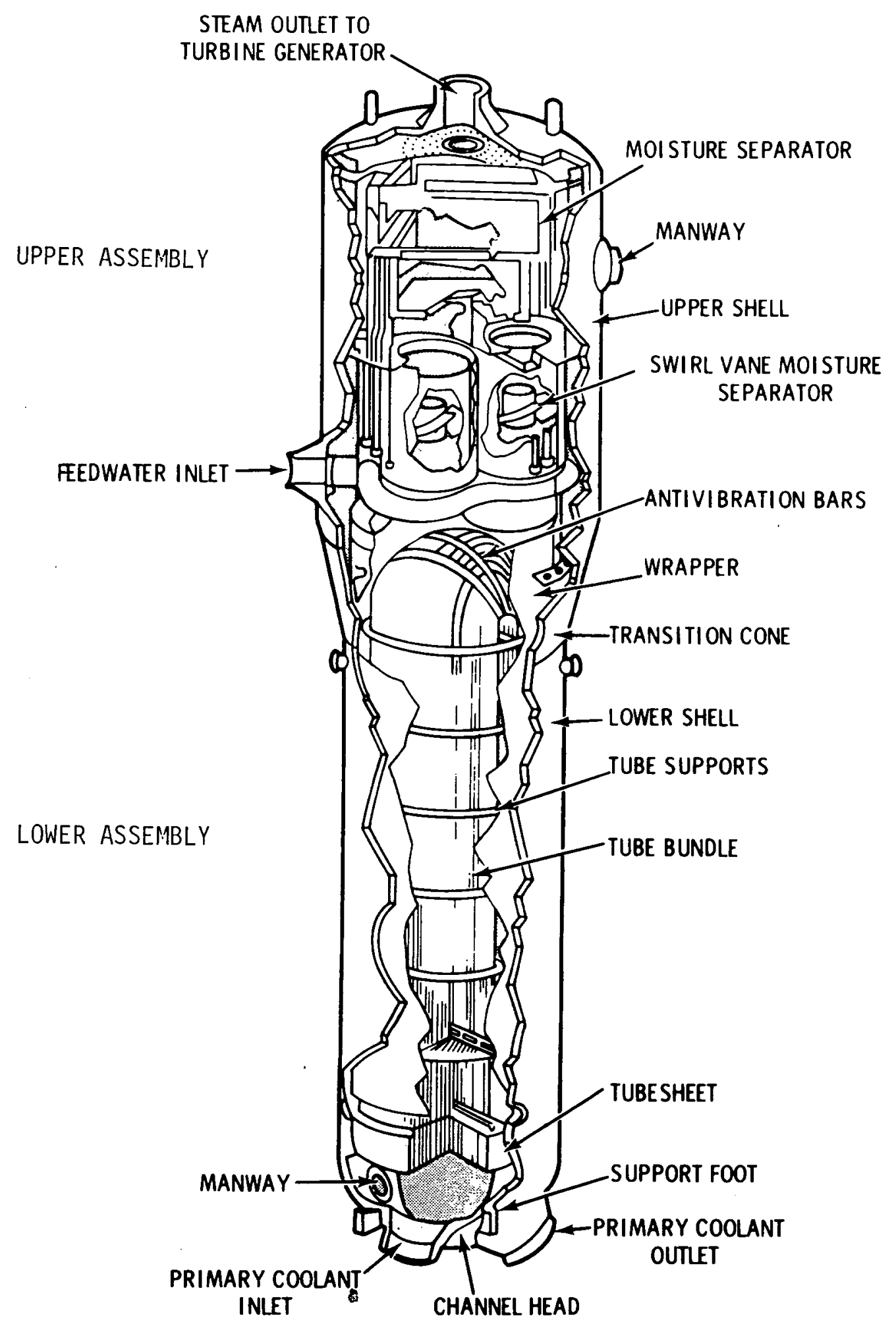

FIGURE 1. Structure of a Generic Recirculating Steam Generator 
Brief descriptions of the sequence of steps used in each of these cuts are provided in the following discussions on the steam generator removals at Surry Unit 1 and Turkey Point Units 3 and 4.

\subsection{REACTOR COOLANT PIPE CUT AT SURRY UNIT 1}

The Surry Generating Station is a two-unit, three-loop plant. Unit 1 was placed into service in July 1972 and Unit 2 in March 1973. Phosphate secondarywater chemistry was used until early 1975 when the utility changed to an allvolatile treatment. Corrosion-related phenomena caused thinning, denting, and cracking of the tubes and degradation of the support plates, requiring extensive tube plugging. Prior to replacement, $25.4 \%$ of the tubes in Unit 1 and $21.5 \%$ of the tubes in Unit 2 had been plugged (McKay 1982). Continued operation would have led to reduced reliability, and the units would eventually have been derated.

The replacement of the Unit 2 steam generator, begun in February 1979 and completed in December 1979, was the first such major steam generator repair. The sequence of the replacement events and the resulting occupational doses have been detailed in progress reports from VEPCO to NRC and in numerous other reports and journal articles (Hoenes et a1. 1980). The replacement program for Unit 1 began in September 1980 and extended through June 1981. Many of the lessons learned during the steam generator replacement at Unit 2 were applied at Unit 1. The experience gained at Unit 2 in such tasks as removing the RCP and installing temporary shielding also contributed significantly to the efficient performance of these tasks at Unit 1. As a result, the total occupational radiation dose from replacement activities at Unit 1 was 18\% lower than that at Unit 2, even though the initial dose rates were higher at Unit 1.

At both Unit 2 and Unit 1, the RCP was cut for removal of the steam generators. This method (Figure 2) involves: 1) cutting the steam generator at the transition cone, in order to separate the upper and lower assemblies, 2) cutting the RCP at the steam generator hot-leg nozzle and again at the outlet side of the RCS isolation valve, and 3) cutting the cold-leg pipe at the nozzle and again at the reactor coolant pump. The feedwater inlet pipe and main steam outlet pipe were also segmented. Replacement tasks for both Unit 2 and Unit 1 generally followed those outlined in the final revision of the repair program plans issued by VEPCO (1978).

After completing Unit 2, it was determined that purchasing new RCP, rather than decontaminating and refurbishing the old RCP, would save time, cost, and dose. The tenting design was also changed significantly by making the entire steam generator cubicle into a tent enclosure rather than using small tents. Other differences in the Unit 1 replacement program reflected dose-conserving refinements of the original plans. The steam generators and the Unit 1 RCP were transported to an onsite facility designed for their storage. 


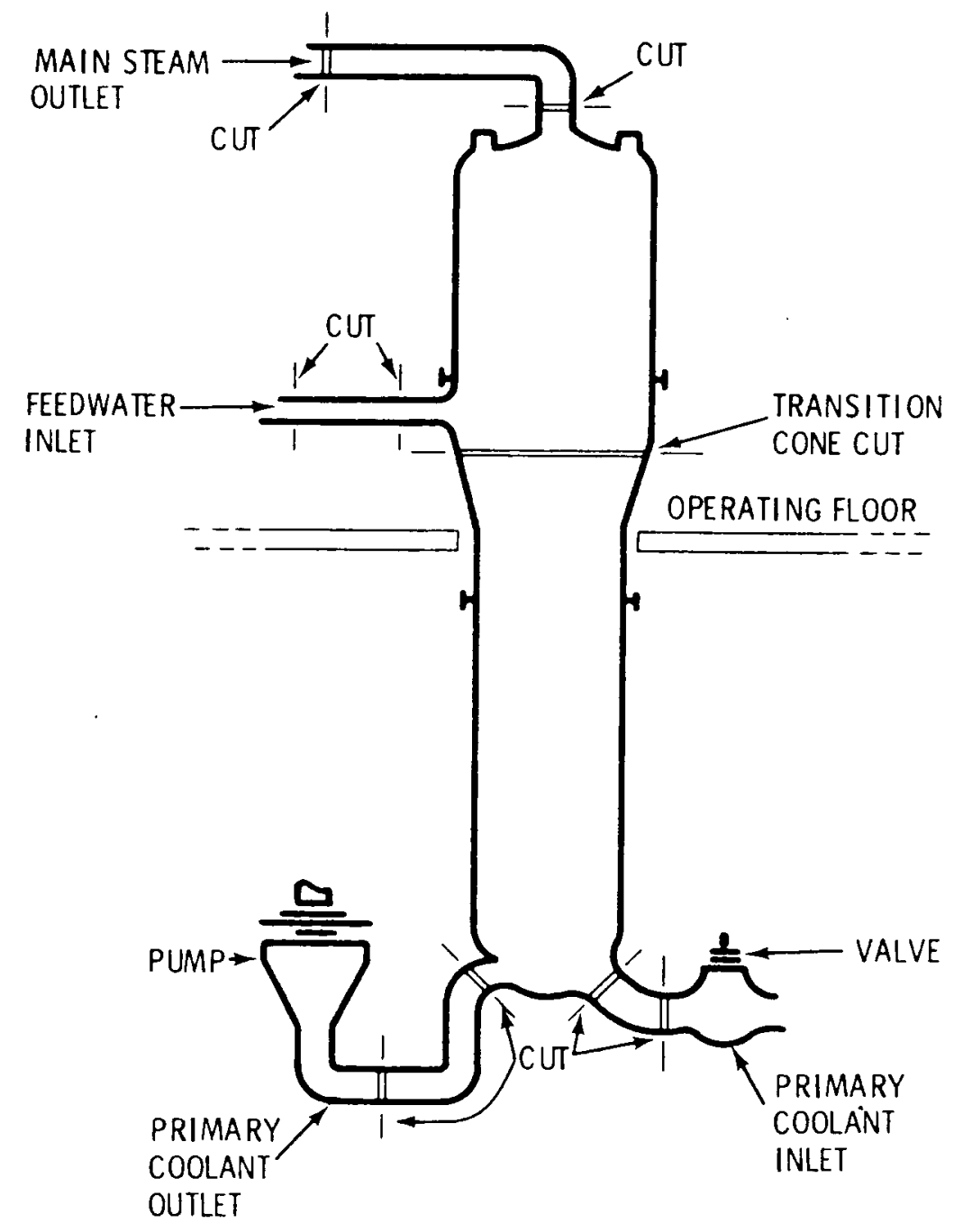

FIGURE 2. Location of Pipe Cuts for Surry Steam Generator Replacements

\subsubsection{Preparations for Steam Generator Removal}

After the shutdown of Unit 1 and the defueling of the reactor, a number of containment modifications were necessary, including the removal of cement block shielding; the installation of temporary scaffolding, power, and lighting; and the installation of jib cranes. The labor force was trained in radiation protection practices; however, many workers were already familiar with most of the procedures because they had been involved in the Unit 2 replacement activities. The containment building was decontaminated to remove loose radioactive contamination and reduce the potential for airborne contamination. Temporary shielding was installed to reduce dose rates, especially around the lower portion of the steam generator cubicles. The cubicles were

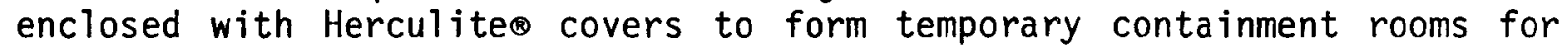
cutting and grinding operations.

(2) Trademark of Pittsburgh Plate Glass Company. 


\subsubsection{Worker Training}

The training program given to all workers involved the extensive use of full-scale mockups and hands-on practice with the equipment to be used, complimented by the use of videotapes of the Unit 2 replacement activities to familiarize workers with the overall effort. Detailed photographs of components, equipment, and work areas at Unit 2 were also used during the training of workers at Unit 1.

\subsubsection{Containment Cleanup}

The initial decontamination and cleaning of the containment building, as well as cleaning and debris removal following the removal of parts of the biological shield and the steam generator insulation, facilitated the work being done and reduced the amount of surface and airborne contamination generated. The continuous cleanup and decontamination of work areas and equipment by a specially designated work crew enabled most workers to do their jobs without using respiratory protection. Only for pipe and component cutting activities were respiratory-protection devices routinely worn.

In addition to this general decontamination, which consisted of scrubbing and water spraying, portions of the exterior of the steam generators where smearable contaminants were detected were painted to fix surface contamination.

\subsubsection{Installation of Temporary Shielding}

Radiation surveys were performed to identify where shielding would be most effective in reducing dose rates to high-traffic and high-occupancy areas. Extensive shielding was installed for the lower steam generator cubicles and the RCP and components prior to the start of cutting activities. Experienced contractors installed the temporary shielding and contamination control tents.

A high water level was maintained in the secondary side of the steam generators to reduce exposures, particularly for work on and near the steam generator shell, such as the removal of shell and RCP insulation, the cutting of the upper shell and mainsteam and feedwater piping, the disassembly of steam generator supports, and the removal of instruments and blowdown piping. The secondary side was drained before the steam generator was removed from containment.

\subsubsection{Containment Control Envelopes}

Temporary containment rooms for cutting and grinding operations were fabricated by enclosing the steam generator cubicles with Herculite. Portable ventilation units withdrew and filtered contaminated air to reduce airborne releases. These cubicles required little setup time and were not liable to be damaged inadvertently by workers as were the small confining tents used in the Unit 2 replacement. Persons working in the enclosures were required to wear respiratory-protection devices during cutting and grinding activities. 


\subsubsection{Steam Generator Removal}

The upper assembly was cut from the lower assembly using an oxyacetylene torch. The lower assembly was separated from the primary system piping using track-mounted plasma arc cutting equipment. The Unit 1 pipe elbows and associated piping were not decontaminated and refurbished, as had been done in Unit 2; instead, they were disposed of and new piping was installed. The moisture separation equipment in the upper assembly was removed and replaced with more efficient equipment.

At Unit 2, plasma arc cutting had been used to cut the RCP. This cutting method takes 15 to 20 minutes per pipe cut, compared with 1 to 4 hours per pipe cut using flame cutting. Plasma arc cutting thus seemed the best choice for keeping occupational doses ALARA. However, difficulty in separating the pipes had resulted at Unit 2 when molten metal, which formed during cutting, collected at the bottom of the cut area. This problem was resolved by cutting the lower half of the pipe first and packing the cut with refractory material, to which the molten metal did not adhere.

\subsubsection{Installation of Replacement Generator}

The upper shell was fitted to the new lower shell following the machining of a weld preparation. The shells were manually welded together and inspected. Weld preparation was also machined onto the new RCP fittings, and the lower assembly was welded to this and other miscellaneous piping. Completion of the replacement activities was followed by hydrostatic testing and flushing the new steam generator systems.

\subsection{CHANNEL HEAD CUT AT TURKEY POINT UNITS 3 AND 4}

The Turkey Point Units 3 and 4 have been operating since December 1972 and September 1973, respectively. The three-loop units began operations with sodium phosphate used for the secondary-water chemistry treatment. Both units were converted to all-volatile chemistry (AVT) in the fall of 1974 to correct the wall thinning typically associated with phosphate treatment.

Prior to their removal, all. six steam generators had undergone significant tube degradation, especially radial deformation (denting) with associated tube leaks and tube wall thinning. There was also evidence of denting-induced deformation of tube support-plate flow slots, cracking of the support-plate ligaments, and $U$-bend cracking of row 1 tubes due to this denting-induced deformation of the support plates. At the time of steam generator replacement, tube degradation had required the plugging of $21.02 \%$ of the Unit 3 tubes and $25.64 \%$ of the Unit 4 tubes. The certainty of additional plugging and substantially reduced heat transfer capacities, with the resulting power derating, was the basis for FP\&L's decision to replace the degraded tube bundles.

Initially, FP\&L planned to replace the steam generators in Unit 4 first and then those in Unit 3. However, because Unit 3 had been down for an extended outage at the time NRC approved the proposed replacements, the utility decided to proceed first with Unit 3, five months earlier than 
planned. At that time, the initial repair plans for Unit 4 were further along than were those for Unit 3. Even though the units have similar physical layouts, numerous differences between Units 3 and 4 made the plans for Unit 4 not completely applicable to Unit 3, and some delays and shortcomings with Unit 3 resulted. The Unit 3 replacement was begun in June 1981 and was completed in April 1982. The Unit 4 replacement was begun in October 1982 and was completed in May 1983.

At Surry where there was inadequate access for a channel head cut, the lower steam generator assembly was completely replaced. At Turkey Point, complete replacement was not feasible because the foundation support system for the steam generators would have hindered the movement of pipes and workmen during cutting and refitting of the RCP. Experience at Surry also showed that removing and refurbishing or replacing the RCP is time-consuming and doseintensive. In addition, realigning the pipe at Turkey Point would have been more difficult than at Surry. Therefore, FP\&L decided to cut the steam generator channel head just below the tubesheet and to replace just the sheli and tube bundle (Figure 3 ). The Unit 3 and Unit 4 lower assemblies were cut with plasma arc and mechanical devices, removed from containment through the existing equipment hatches, with minimal clearance, and transported to the special storage facility for the remainder of the life of the plant, approximately 30 years. The new lower assemblies were positioned and welded onto the channel heads and the upper assemblies.

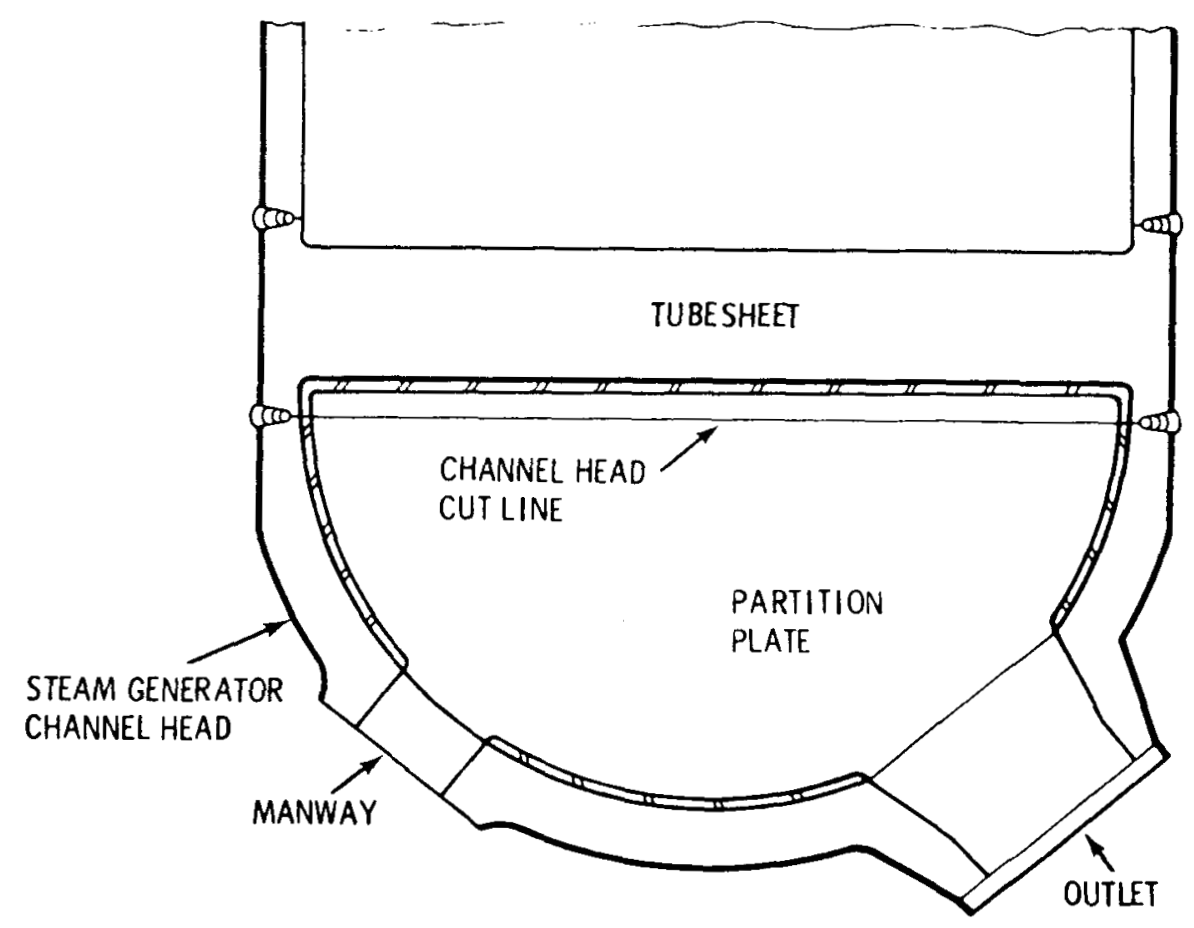

FIGURE 3. A Cross-Section View of the Turkey Point Steam Generator Showing Channel Head Cut Line 


\subsubsection{Preparations for Steam Generator Removal}

Extensive preparations were undertaken before the lower-assembly cuts were made. The construction work force had to be trained in radiation protection practices and in working in radiation zones. A number of preparations were made, including defueling, the installation of a special exhaust vent with a high-efficiency particulate air (HEPA) filter, removal of a portion of the bioshield wall and a section of the operating floor to provide access to the steam generator, and the installation of guide rails for moving the steam generator through the equipment hatch. Polar crane modifications were also necessary.

General area decontamination and the shielding of high-radiation-field components and high-occupancy areas were necessary prior to steam generator removal to keep contamination and exposures down. Numerous concrete walls and electric cables had to be moved or removed so that replacement activities could proceed smoothly. The channel heads were decontaminated, and containment envelopes were assembled to isolate cutting and grinding operations.

A steam generator storage building was constructed, and a laydown area was built outside containment for temporary storage of the Unit 3 steam generators, which were removed from containment before the storage building was completed.

\subsubsection{Worker Training}

The large labor force needed for the replacement of the steam generators went through a plant-sponsored training program prior to working in the reactor building. Craftsmen and supervisors needing unescorted access to controlled areas were given a 20 -hour course in radiation protection, including instruction in the theory and demonstration of the practice of radiation protection, emergency planning, and the FP\&L radiation protection program. Successful completion of classroom work and a comprehensive examination qualified the workers for unescorted access. Those workers not requiring unescorted status were given a 3 -hour orientation course on basic health physics practices and emergency procedures.

A scale model of Units 3 and 4 was used to orient personnel to the arrangement of the containment building and to the locations where each individual would be working. A mockup of a steam generator channel head was available so that those working in or around the channel head could practice making entries. The channel heads from the new steam generators, which were cut just below the tubesheet, were used to train personnel in the proper methods for cutting and welding the channel heads and divider plates.

\subsubsection{Shielding}

Lead sheeting, blankets, and wool were used to shield components that caused significant exposure rates in areas of high traffic or extensive occupancy. More shielding was installed than had originally been planned, and its installation was responsible for a very large, although not totally 
quantifiable, dose savings. Wherever possible, shielding was used to reduce dose rates to $10 \mathrm{mR} / \mathrm{hr}$ or less. Much of the temporary lead sheeting installed was pre-formed shielding that FP\&L had acquired from the Surry replacement. A separate work package was established for the installation of shielding, and records were kept that included the locations of shielding, the types used, survey data prior to and after the shielding was installed, stress analysis results, and engineering approvals of free-standing supports.

Some of the components or systems shielded included the reactor head, to reduce the dose rates associated with preparations for hot functional testing and with removal of the head afterwards; various parts of the decontamination grit blast system; transfer lines carrying the used grit from containment to the radwaste building; and personnel monitoring stations, during the removal of the lower assemblies from the reactor containment building. Additionally, lead wool shielding was installed in the channel head nozzles and bowl and next to the divider plate before and during the installation of the new lower assemblies. This shielding reduced dose rates by a factor of 10 in the channel heads.

Maintaining a high water level in the secondary side of the steam generator helped shield the workers from radiation in the tubes and was instrumental in keeping doses low during the numerous operations that took place near the lower assembly. The water level also reduced dose rates from $4 \mathrm{mR} / \mathrm{hr}$ to about $1 \mathrm{mR} / \mathrm{hr}$ at $60 \mathrm{ft}$ away from the lower assembly while it was in temporary storage outside containment (FP\&L 1981). The water was drained from the steam generators prior to their transfer to the storage facility. As expected, the activity of this water was less than $0.017 \mathrm{mCi}$ (mainly ${ }^{60} \mathrm{Co}$ ).

\subsubsection{General-Area Decontamination}

Extensive decontamination of the containment building was performed prior to removal activities to reduce surface contamination and minimize the potential for airborne radionuclides. Major items and components, especially those to be removed later, were decontaminated to about 1000 to $3000 \mathrm{dpm} / 100 \mathrm{~cm}^{2}$ using scrub brushes, a Turco solvent, and water. Floor coverings such as Herculite and similar plastics were used where appropriate. The general-area decontamination process greatly reduced the need for respiratory-protection devices.

\subsubsection{Contamination Control Envelopes}

The cleanup and decontamination of the containment building effectively minimized the levels of airborne contamination, but highly contaminated components (such as those in the primary recirculating system) required isolation during cutting and grinding operations. For these operations, FP\&L used contamination control envelopes with HEPA filtration units and a ventilation system. A secondary exhaust system provided additional air exchange and maintained a negative pressure when personnel hatches and equipment hatches were open. Filtered air was discharged through the monitored plant stack via the

Trademark of Turco Products, Division of Purex Corporation. 
containment ventilation system. Although plastic tents were used, most of the envelopes were constructed of aluminum and required little assembly time while offering superior fire protection.

\subsubsection{Decontamination of the Channel Heads}

Cutting at the channel head avoided certain removal difficulties but created the need for channel head decontamination to control exposure. A highly effective decontamination technique, alumina grit blasting (Sejvar and Dawson 1982, Card 1983), was chosen to reduce radiation levels. This method produces relatively high decontamination factors (DFs) and does not generate much solid waste. However, because of the possibility that residue left in the tubes may affect heat transfer characteristics, this decontamination method has not commonly been used for operational steam generators. At Turkey Point, further damage to the original tubes was not a concern since the tubes were being replaced.

Testing of the decontamination process showed that two passes of the grit blast sequence were sufficient to obtain a satisfactory DF in the channel heads without undue cost, delays, or waste volume. The decontamination vendor used remote operations as much as possible to minimize occupancy in the highexposure areas of the manway and channel head. A "remote arm" manipulator was set up in the channel head and, except for occasional maintenance or repairs, required only one entry for installation and one entry for removal for each side of the channel head. A temporary manway cover with disconnect hoses helped shield the decontamination workers and reduce the time spent at the manway.

The use of a recirculating system permitted reuse of the decontamination water after filtration. The specific activity of the water was about $10^{-3}$ to $10^{-4} \mu \mathrm{Ci} / \mathrm{g}$ (Sejvar and Dawson 1982). The waste grit from Unit 3 operations, which had an activity level about $10^{4}$ higher than that of the water, was routed to a solidification/shipping cask inside containment. In Unit 4, the mixing container and waste grit were handled outside of containment in the radwaste building.

During the Unit 3 decontamination operations, there were a number of electrical and mechanical problems in operating the grit blast system. Good flow characteristics were not achieved largely because of faulty potentiometers. The system was made more mechanically reliable for the Unit 4 decontamination, and the arrangement and programming of the manipulator spray arm attachment were modified to better decontaminate the manway and the environmental ledge (the small ledge beneath some steam generator tubesheets).

The decontamination process was extremely effective in lowering surface contamination and dose rates. The dose reduction factors (DRFs) achieved were quite significant. In the Unit 3 channel heads, the initial dose rates in the center of the channel head were 11 to $13 \mathrm{R} / \mathrm{hr}$ and averaged $12 \mathrm{R} / \mathrm{hr}$. After the decontamination and shielding of the nozzle and the removal of the tubesheet, the dose rates were reduced to an average of $400 \mathrm{mR} / \mathrm{hr}$. If it is assumed that the dose rate is $12 \mathrm{R} / \mathrm{hr} 6$ inches from the tubesheet, removing the tubesheet would reduce the field to about $6 \mathrm{R} / \mathrm{hr}$. Using $6 \mathrm{R} / \mathrm{hr}$ as the initial reading 
for the calculation, the DRF is about 15. After partial decontamination, manway openings had dose rates of about $1 \mathrm{R} / \mathrm{hr}$ (FP\&L 1981).

In Unit 4 , the dose rates in the center of the channel heads averaged $8.5 \mathrm{R} / \mathrm{hr}$, with a range of 8 to $11 \mathrm{R} / \mathrm{hr}$. After the channel heads were decontaminated, nozzle shielding was installed, and the tubesheet was removed, the dose rates were reduced to about $200 \mathrm{mR} / \mathrm{hr}$. This gives an effective DRF of about 25 . The dose rate at the manway openings was reduced to $250 \mathrm{mR} / \mathrm{hr}$ (FP\&L 1983b).

\subsubsection{Steam Generator Removal}

The removal of the steam generators required two major cuts: 1) the upper cut, which separated the moisture separation equipment of the upper assembly from the tube bundle and the channel head of the lower assembly; and 2) the lower cut, which separated the tubesheet and tube bundle from the channel head. The upper cut was done manually using an oxyacetylene torch. The outlet pipe on the upper assembly was also cut, and the upper assembly was then removed by crane from the top of the steam generator. The internal moisture separators were removed and refurbished or replaced.

Because the lower cut was expected to be especially dose intensive, FP\&L conducted tests on the Unit 3 channel heads to determine whether the use of a manual plasma arc torch or the use of a remotely operated cutting machine resulted in more exposure. The cutting would be followed by the application of welding preparation for the installation of the new steam generators. The two methods involved almost the same levels of exposure. However, the machine cut took 6 days to complete versus 1 day for the manual flame cut. After the mechanical equipment was improved, the decision was made to cut the Unit 4 lower girths by machine and to bevel the cuts so that most of the welding could be done from the outside, thereby reducing the cutting time and the doses involved in channel head entries.

Prior to the removal of each lower assembly, the divider plate between the hot and cold legs was severed from the tubesheet using a plasma arc torch on Unit 3 and a remotely operated flame cutter on Unit 4.

A section was cut out of the divider plate to allow access to the hot leg from the cold-leg side for cutting and welding operations. High ambient temperatures and the preheating temperatures required for weiding caused uncomfortably hot temperatures in the channel heads. Cool air directed to the manway was the only available means of improving this situation.

After all cutting was complete and the secondary sides were drained of water, metal shield covers were welded over the ends of the lower assemblies. The lower assemblies were then picked up by cranes and moved to the laydown area. As already discussed, the Unit 3 steam generators were temporarily stored outside the building until the onsite storage facility was completed. The assemblies were then transported to the storage facility. The Unit 4 steam generators were moved directly out of the equipment hatch to the storage building. 


\subsubsection{Installation of Replacement Generator}

The channel head remnants were prepared for the installation of the new lower assemblies. Temporary protective covers were fastened to the tubesheets to protect the tubes from welding smoke. The protective layers were not very effective in Unit 3, and the tubes had to be cleaned and inspected as a result of smoke penetration. Improved tubesheet coverings in Unit 4 were much more effective.

Mirror insulation, cut to fit, was installed on the exterior of the Unit 3 steam generators. The Unit 4 steam generators were insulated using flexible lagging with a blanket-type fit that did not require extensive measurements and greatly decreased installation time.

Most of the post-installation activities consisted of reinstalling piping and removing temporary shielding and scaffolding. Hot functional testing of the system was also a part of this phase. 


\subsection{DESCRIPTION OF TUBE REPAIR TECHNIQUES}

Tube repair has traditionally been handled by plugging the leaking or damaged tubes. This approach takes the tube out of service, and when large numbers of tubes in a steam generator are plugged, the heat exchange capacity declines and the unit has to be derated. While tube plugging is still necessary for a variety of tube maladies, tubes that are damaged at certain locations, such as at the tubesheet boundary, can be repaired by the insertion and sealing of a tube sleeve. The tube sleeve spans the damaged area, usually within or just above the tubesheet, and allows the tube to remain in service. A third method of tube repair, which has been demonstrated in a nonradioactive environment but has not yet been tried in an actual situation, is inplace retubing.

Large-scale sleeving was first attempted at San Onofre in 1980 to 1981. The project was largely a developmental one initiated after laboratory tests proved the feasibility of extensive sleeving during an outage. As with many projects moving from pilot study to large-scale installation, there were problems to overcome, many of which were solved by manual and remote-tooling modifications as the sleeving project progressed. The conditions at the San Onofre steam generators, such as sludge buildup and tubes locked at the first support plate, presented the majority of the problems.

The next large-scale sleeving effort was undertaken at Indian Point Unit 3 in late 1982 to early 1983, followed by Point Beach in May to June of 1983. The many engineering and tooling improvements made by then and the experience gained at San Onofre greatly reduced the time and exposure required for the sleeving at these plants.

The techniques used for sleeve expansion and sealing during the R. E. Ginna sleeving operations in April to May of 1983 were significantly different from the techniques used at the other plants. Developmental work was also necessary at Ginna to determine an appropriate method for sleeving tubes that were locked into the first support plate.

The plugging and sleeving processes are described in the following two sections. Most of the background information on these tube repair techniques was provided by Babcock \& Wilcox Co. and Westinghouse Electric Corp. in their published literature and through discussions with their personnel. Discussions of the specific sleeving operations used at the San Onofre Unit 1 , Point Beach Unit 2, and R. E. Ginna power plants are included in Sections 4.3 to 4.5. Most of the information contained in these sections was obtained from plant personnel and the tube repair subcontractors.

- The inplace retubing process is described in NUREG/CR-1595 and has recently been discussed elsewhere (Cooper u.d., Estes, et al. 1979); therefore, it will not be described further here. Retubing may be attempted in the future, particularly for plants where the equipment hatch is not large enough to accommodate the steam generators or where the hatch is so located that it is not possible to remove the steam generator without extensive piant modification. 


\subsection{PLUGGING}

When defects or certain types of damage have been detected during tube inspection, the tubes have typically been plugged to prevent further degradation that could result in significant leaks between the primary and secondary systems. A number of types of plugs are currently on the market and a few others have been discontinued.

The original tube plugs were manually welded in place. This process is dose-intensive and slow, and a good seal can not be obtained if boric acid crystals are present at the weld surface. Current manual installation takes about 4 minutes per plug. Semiautomatic welding machines are undergoing modification to reduce the in-generator time needed for installation of these plugs. This technology is still used for plugging the tubesheet where tubes have been pulled.

Explosive plugs came into use early in the 1970s. The installation of some early types was dangerous and time-consuming and resulted in high occupational doses. Furthermore, these plugs could crack under certain conditions. The current generation of explosive plugs and the automated installation equipment now widely in use, offer much higher reliability and reduced exposures. The installation of these newer explosive plugs is rapid, results in a good seal, presents minimal problems with airborne contamination, and is a much safer operation than installation of the old explosive plugs. The exposure to licensed blasters is in the millirem range, and installation does not require the presence of additional specialized personnel such as welders. The explosive plug is designed for permanent installation, and about 3 minutes inside the channel head are required for the installation of each plug.

The rolled mechanical plug, another recent development, provides high reliability with minimum installation time and can be removed with minimal tube damage should the decision later be made to return the tube to service by sleeving. Mockup testing of manual tube cleaning, plug installation, and equipment removal takes about 2 minutes per plug. The plug can be installed using a remote manipulator. Unlike explosive and welded plugs, which have to be cut out for removal, mechanical plugs can be removed quickly and easily and without damaging the tubes.

Another new type of mechanical plug has ribs that bear into the tube for a good seal. These mandrel-ribbed plugs require no tube cleaning as long as there are no obstructions; and they can be machine-installed in seconds in a batch process. The plugs are designed for permanent installation: removal of the plug would leave an impression on the inner surface of the tube and perhaps cause some tube damage.

\subsection{SLEEVING}

There are two major strategies for tube preparation and sleeving. The first uses hydraulic expansion followed by a mechanical rolled or brazed seal; the second uses explosive expansion and welding and produces a brazed seal. The application of the rolled seal is a more rapid process that produces a snug mechanical seal with the tube at the upper and lower joints. The 
application of the brazed seal following expansion of the sleeve takes longer but creates a metallurgical bond at the tube and sleeve boundary, in addition to a snug mechanical seal. Both processes have been automated to reduce the number of channel head entries.

Most sleeves currently being installed are made of mono- or bi-metallic, thermaliy treated Inconel@ 600. The brazing material is typically BAu-4 and the joint is commonly referred to as a gold braze. The sleeve length varies with the location of the tube damage. Most sleeves range from 28 to at least 44 in. A "tubesheet sleeve" of about 22 in. is also available, and at least one vendor has developed a minisleeve to patch defects near the bottom of the tubesheet. The minisleeves are thin, manualiy or remotely installed sleeves that are explosively welded to the tube, which can be resleeved with a conventional length sleeve later if necessary.

Tubes along the periphery of the channel head bowl are difficult to sleeve because the geometry of the bowl does not provide the clearance necessary for insertion of the sleeve. Developments to handle this problem include a curved sleeve that can be installed and straightened in one step and, where possible, the use of shorter sleeves when the damage is near the tubesheet crevice. The feasibility of sleeving plugged tubes has been demonstrated where the tube damage is within or just above the tubesheet; this procedure allows the recovery of some tubes that have been taken out of service.

The two major sleeving processes are described in the following paragraphs. The steps listed for each process are generally performed in batches. Representations of the fit of a sleeve inside the tube for each case are illustrated in Figures 4 and 5.

\subsubsection{Sleeving Using Hydraulic Expansion and a Rolled Seal}

The sequence of steps for sleeving using hydraulic expansion and a rolled seal is as follows: tube cleaning, sleeve insertion and hydraulic expansion, lower joint seal, upper joint seal, and sleeve inspection. The tube is cleaned with a rotating hone to remove the oxide film on the tube's inner surfaces. The tube-cleaning procedure produces no airborne contamination and may have an added beneficial effect in slightly lowering the channel head dose rate by reducing the contribution from tube shine. A statistical sample of tubes is then inspected for cleanliness using fiberoptics and an imagerecording system. The cleaning, inspection, and recording systems are all positioned by the same remotely controlled robotic system.

The sleeve loader is fitted with a mandrel and a high-pressure water supply system to hydraulically expand the sleeve so that it makes contact with the tube. The mandrel/sleeve assembly is positioned either manually or remotely and is driven up the tube to the full length of the sleeve. The sleeve is expanded at the top and bottom at the same time. The mandrel is then removed and the next mandrel/sleeve assembly is put into position.

- Trademark of the International Nickel Company, Inc. 


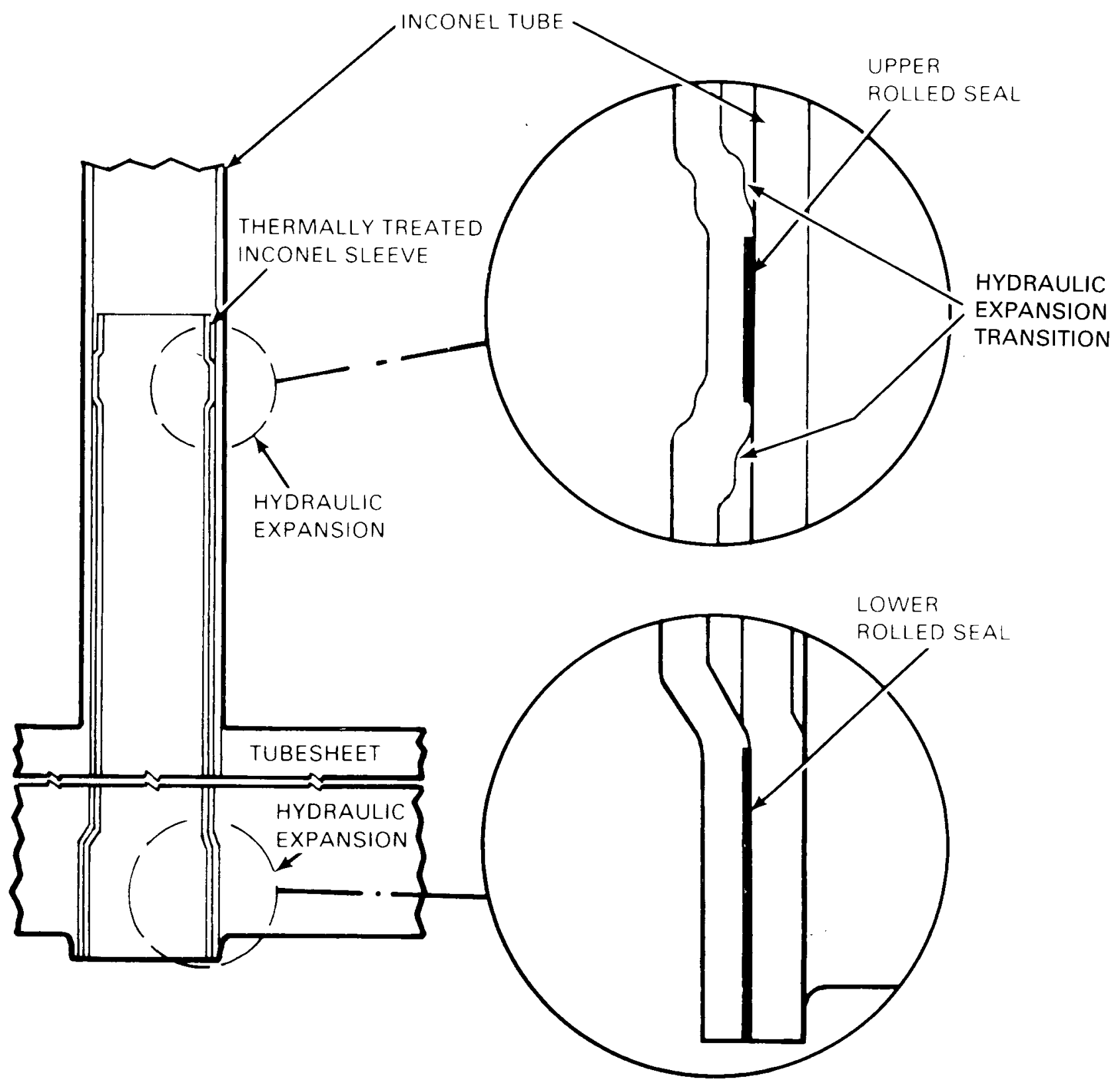

FIGURE 4. A Tube Sleeve Hydraulically Expanded and Roll Sealed at the Upper and Lower Joints 


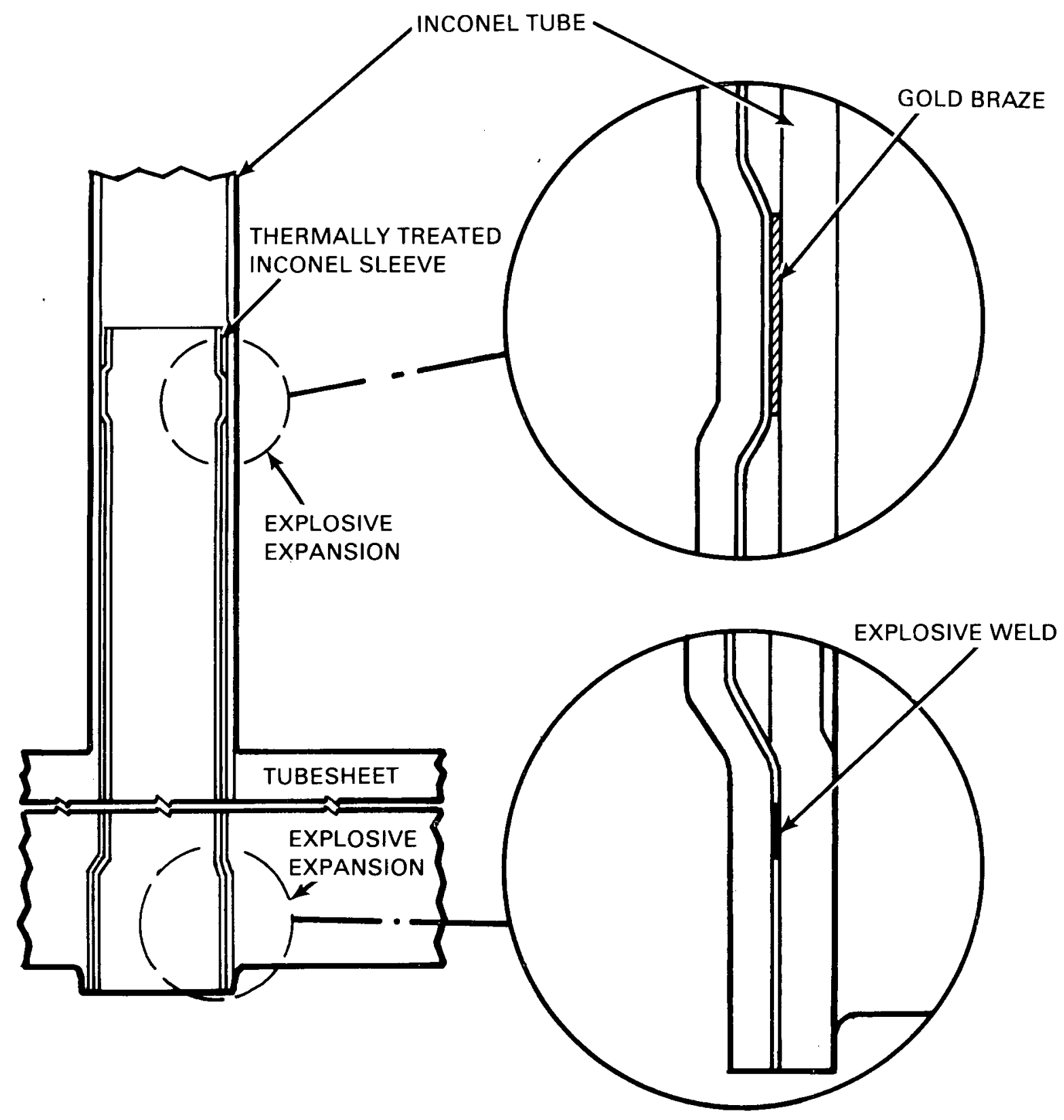

FIGURE 5. A Tube Sleeve Explosively Expanded and Sealed at Upper and Lower Joints with a Braze and an Explosive Weld 
After each sleeve has been positioned and expanded, a roll expander driven by an air or hydraulic motor makes a leakproof, rolled seal between the sleeve and the tube in the lower tube end. The upper seal can be rolled or brazed, depending on tube circumstances. Most of the hydraulically expanded sleeves have been sealed with an upper roll. The expansion and the rolled seals on each sleeve are checked using eddy current testing.

\subsubsection{Sleeving Using Explosive Expansion and a Brazed Seal}

The sequence of operations for sleeving using explosive expansion and brazed upper bonds is similar to that discussed above. A swab-hone assembly cleans the upper and lower expansion regions of the tube, concentrating especially on the upper region. The sleeve is inserted and the upper end is explosively expanded to the tube in the area of the brazing rings. This expansion is made by a precise, controlled explosion that is quiet and safe. The vendor believes this to be a faster and more trouble-free process than hydraulic expansion. The brazed bond is completed by inserting a heating wand up the tube and raising the temperature to get a good braze. The temperature is then reduced and the whole zone is given a thermal treatment to condition it against corrosion. Following the brazing treatment of the upper section, the lower section is explosively welded to the tube. As with the hydraulic expansion-rolled seal strategy, all of these operations can be done remotely.

\subsection{SLEEVING AT SAN ONOFRE UNIT 1}

San Onofre Unit 1 began operation in 1968. Sodium phosphate has been used for secondary-side water treatment throughout the entire operating history except for 5 months during 1970 and 1971. The plant makeup water initially was evaporated sea water, but was changed to San Clemente city water in 1978. Early fluctuations in the $\mathrm{Na}: \mathrm{PO}_{4}$ ratio were attributed to sea water leakage from the condenser into the secondary side. Condenser leakage was controlled from 1974 to 1978 and then increased significantly in 1979 and 1980. During this period the reactor went through numerous shutdown and startup cycles because the lack of electrical demand did not justify continuous operation. These shutdown and startup cycles and the hardness of the city water have contributed to the accumulation of phosphates near the tubesheet. Inservice inspections of the steam generator tubes, performed since 1972, have indicated that tube degradation has been caused by antivibration bar wear, denting, general phosphate wastage, and intergranular attack. During eddy current inspections in August of 1980, many indications of intergranular attack were found in the central region of the hot leg (primary inlet) of each of the three Unit 1 steam generators. Because no replacement lower assemblies were available, the decision was made to undertake a major sleeving effort. The discovery of the intergranular-attack problem, the decision to sleeve, and the beginning of the steam generator decontamination task occurred over a 2to 3-week interval, leaving little time for planning or preparations.

\subsubsection{Sleeving Preparations}

Because no large component had to be removed from the steam generators, modifications inside the containment area were not extensive. A three- 
compartment decontamination area was erected on scaffolding just inside the equipment hatch, and other tents were placed in low-exposure areas where additional decontamination and repair could be performed. To minimize the impact of the sleeving on plant activities, a separate access for steam generator repair personnel was constructed on the north side of the project area. A wooden access control building was erected on the turbine deck to store supplies and to provide a final station for suit-up and frisk-out. Work platforms were constructed below the manway at each steam generator.

Estimates of the occupational dose for decontaminating the channel heads and sleeving the tubes showed that this project would require many channel head workers. Much of the temporary labor force had no previous radiation zone experience and had to be extensively trained.

Shielding was used to reduce dose rates in high-occupancy areas, and the channel heads were decontaminated to reduce the dose rates and surface contamination for those workers making channel head entries. Routine work associated with the steam generator project included housekeeping and containment cleanup. Exposures resulting from these activities were followed and tabulated using special radiation exposure permits.

\subsubsection{Training of Workers}

The station's existing training program in radiation protection was used to train company and vendor personnel, as well as contracted health physics personnel and steam generator workers. The basic radiation protection training included (Malinowski 1980): eight hours of classroom instruction related to 10 CFR 19-12, dress-out training in full protective clothing, and respiratory protection training. In addition, all personnel with duties in or near the steam generator received job specific training and full dress-out and channel head mockup training in a simulated platform environment, where each individual was checked for speed and proficiency. Refresher classes were held as necessary.

Other personnel received system reviews and walk-throughs for the decontamination, honing, and sleeving processes. Health physics personnel received 4 hours of instruction on equipment, and observed entries into the mockup steam generator. Video tapes of previous and ongoing steam generator repair activities at San Onofre were used to familiarize personnel with the containment work areas and ALARA measures being used during the project. Television monitors in various locations permitted workers to watch as the steam generator was repaired.

\subsubsection{Shielding}

A containment shielding program was implemented to reduce work area dose rates from hot spots and components. High-traffic and high-occupancy areas especially were shielded. In the channel head, a specialized shielding of lead sheets on aluminum plates was designed for the cold leg divider plate, the channel head bowl, the inlet nozzle, and the tubesheet. The tubesheet 
shielding was less useful than anticipated because it had to be moved frequently. Additional shielding outside the steam generator to reduce dose rates is listed below.

- Manway shield covers were installed around the cold leg in order to reduce the radiation levels on the platforms. The shields consisted of iron plates held in place by manway bolts.

- Platform waiting areas were surrounded by lead blankets to protect platform and channel head workers.

- Racks supporting lead blankets were installed as a shield wall between the steam generator exterior and nearby occupied catwalks and step-off pads.

- Shielding was installed on the channel head bowl and cold leg divider plate to reduce the dose rates for those working inside. It consisted of lead blankets suspended from rigid, prefabricated metal work above and below the environmental ledge. In addition, lead blankets were draped on the surfaces of the channel head bowl.

- A segmented shield was installed on top of the inlet nozzle cover to reduce the dose rates from the inlet piping and nozzle surfaces, which were not accessible when the decontamination equipment was in place. Shield segments were fabricated from sheet lead and individually wrapped in a protective Herculite cover. An equivalent thickness of $1 / 2$ to 2 in. of lead was provided over each inlet nozzle.

- The residual activity on the tubesheet and honed portion of the tubes, as well as on the unhoned tube surfaces, was shielded using a segmented tubesheet shield. Each segment of tubesheet shielding was fabricated from sheet lead sandwiched between aluminum plates. Cam-locks were used to install the shields at the face of the tubesheet. Stand-offs and protective covering on the edges of the pieces prevented contact of the aluminum and lead with the surfaces of the steam generator. The removal of appropriate shield segments permitted hands-on operations to be performed while the remaining segments provided shielding of the adjacent tubes. Segments were reinstalled in sleeved tubes by replacing the original cam-locks with those of a smaller diameter.

- Many of the RCS piping and components were shielded.

- Water shields and lead blankets were used to shield the decontamination tanks, separators, pumps, and filters. The waste-grit tank was shielded with lead blankets. Spent filters and hones were stored and then removed in shielded casks.

The containment shielding program reduced the average exposure rate for steam generator project personnel by $59 \%$. 


\subsubsection{Decontamination Process}

Decontamination of the channel head started on September 8, 1980, and was completed on November 10, 1980. The decontamination process used was magnetite grit blast, which involved directing a high-pressure water jet containing magnetite grit at the channel head surfaces. The water from the slurry was recycled with dry magnetite, and the contaminated grit was collected in a waste-grit tank and on filters. The major system component was a remotely operated, computer controlled $X-Y$ manipulator arm. The average dose rates prior to magnetite decontamination were $7.5 \mathrm{R} / \mathrm{hr}$ in the channel head area and $10.0 \mathrm{R} / \mathrm{hr}$ in contact with the tubesheet. Upon completion of the decontamination effort, the average dose rates were $4.0 \mathrm{R} / \mathrm{hr}$ in the channel head area and $6.7 \mathrm{R} / \mathrm{hr}$ at the tubesheet. The average exposure reduction resulting from the channel head decontamination was thus $3.5 \mathrm{R} / \mathrm{hr}$, or $47 \%$ (a DRF of slightly less than 2).

The channel head decontamination took longer than anticipated and resulted in more dose because of numerous problems in handiing the magnetite grit, which tended to plug hoses and nozzles. The scheduled decontamination activities included: the installation and removal of decontamination equipment, the decontamination operation, filter changeout, the replacement of the bypass valve, the maintenance of the grit line, the repair of the highpressure pump, and the installation of the nozzle shield. The dose resulting from these scheduled events was 116 man-rem, or $67 \%$ of the dose from the decontamination program.

The unscheduled events resulting from the grit blast decontamination and the doses associated with these events were:

$$
\begin{aligned}
& \text { Nozzle cover repair and loop seal problems } \\
& \text { Decontamination arm problems } \\
& \text { Grit line and leaking manway problems } \\
& \text { Shielding installation } \\
& \text { Bare-hole plug installation }
\end{aligned}
$$

28.5 man-rem

22.8 man-rem

2.6 man-rem

1.8 man-rem

1.0 man-rem.

The dose resulting from the unscheduled events was about 57 man-rem, or $33 \%$ of the dose from the decontamination program (Allen and Dodson 1981).

\subsubsection{Sleeving Process}

Sleeving at San Onofre was done only in the hot leg, where the damage caused by intergranular attack was apparent.

\subsubsection{Tube Cleaning/Honing}

The tube cleaning program started October 13, 1980, and was completed January 16, 1981. The tube surfaces were prepared for sleeve installation by tube cleaning (honing). A remotely operated positioner arm directed the hone into each tube. Hones were then inserted and withdrawn by a remotely operated probe pusher located outside the channel head. A water spray was operated during honing to remove the contamination and this drainage was then directed 
to the waste-processing equipment. The average exposure reduction resulting from the tube-cleaning effort was $2.0 \mathrm{R} / \mathrm{hr}$, or $50 \%$ (DRF approximately 2).

The dose resulting from scheduled cleaning activities was 174 man-rem. This represents $62 \%$ of the honing program dose. Unanticipated problems with equipment required maintenance, repair, and fiberscoping of the tubes, which accounted for an additional 105 man-rem.

\subsubsection{Sleeve Installation}

The sleeve installation program started January 8 , 1981, and testing was completed June 8, 1981, with the installation of 6900 sleeves. The sleeving vendor used three different sleeve lengths to cover the sections of the hotleg that showed signs of intergranular attack. The sleeves were installed both manually and with automatic tooling, and were hydraulically expanded at the upper and lower joints. The lower joints were rolled, and initially, the upper joints were brazed. However, sludge buildup and other tube conditions prevented a good bond on a number of the tubes, as detected by ultrasonic inspection equipment. The vendor therefore chose to roll the remainder of the top joints to obtain the necessary seal integrity.

The exposure resulting from scheduled events during sleeving was 2155 man-rem. Unscheduled repairs and sleeving rework resulted in an additional 620 man-rem.

\subsubsection{Special Tests and Programs}

Between November 1980 and June 1981, a number of tests were performed intermittently in conjunction with the sleeving program. These tests, which included sleeve tests, inspection tests, and hydrostatic tests, resulted in exposures of 118 man-rem (Allen and Dodson 1981).

Following the sleeving, the baseline eddy current testing was conducted on the steam generator tubes during the end of April and the first week of May, 1981. The total exposure resulting from the baseline eddy current testing was 42 man-rem.

\subsection{SLEEVING AT POINT BEACH UNIT 2}

Operation of the Point Beach Nuclear Plant Unit 2 was initiated in 1972. As was common practice at that time, sodium phosphate water chemistry was used for secondary-side treatment. Following an outage in October to November 1974, the secondary-water treatment was changed to use a volatile chemistry.

The steam generator was inspected at each refueling outage, and a 1974 inspection indicated wall thinning of 145 tubes of the A steam generator and 137 tubes of the B steam generator. Three tubes were explosively plugged in the A steam generator and four tubes explosively plugged in the B steam generator at that time. Testing in 1975 revealed denting in about $20 \%$ of the 
tubes tested. In general, denting, phosphate wasting, and intergranular attack (due to caustic corrosion) have been the main causes of tube damage in the Point Beach steam generator.

In April 1983, the sleeving of 1500 tubes in each steam generator was begun. This activity was completed in June, a few days ahead of the projected schedule.

\subsubsection{Sleeving Preparations}

Because of the large containment area at the Point Beach generating facility, no modifications were required inside containment. The area immediately beneath the reactor and steam generators (at the El. 10-ft) was entirely enclosed with Herculite to contain contamination and airborne activity. A small tool-decontamination facility was attached to this enclosed area. Work platforms located at the manway in each steam generator provided easy access for channel head entry. A shield wall was constructed on the work platform to provide a low-background area where channel head workers could rest when not changing mandrels.

Two areas requiring special consideration in the preparation for sleeving were the training of support workers and the decontamination of the channel head.

\subsubsection{Training of Workers}

Three groups were trained for the Point Beach sleeving outage: primarycontractor personnel, contract health physics technicians, and channel head workers. All groups received the plant's regular site-specific and health physics training programs, which lasted approximately 6 hours.

Point Beach maintains a sole-source contract for health physics support personnel during outages, and plant personnel select contracted technicians. Most of the technicians who were involved in the sleeving outage had been associated with two or three previous outages at Point Beach. Therefore, requirements for additional training for contractor health physics personnel were minimal. The health physics technicians received approximately 5 days of training prior to their involvement with the sleeving project. The training included 3 days of classroom instruction to familiarize the technicians with the Point Beach Nuclear Plant Health Physics procedures, and 2 days of facility orientation.

Because most of the 118 channel head workers who worked on the Point Beach sleeving had no previous experience in reactors or radiation zones, an extensive training program for the channel head workers was developed in conjunction with the primary contractor. The additional training for the channel head workers was given over a 5-day period for 12 hours per day. The training facility contained a mockup of the channel head, a display of the manual tools used in the sleeving process, and a "think-tank" template where trainees, watched by their peers, practiced identifying tubes. The training course included a full dress rehearsal for each trainee, including 
the use of supplied air respirators. The course was designed to allow as much one-to-one training as possible. Extra time was spent with individual trainees as necessary. Throughout the training, radiation protection and ALARA principles were constantiy reinforced.

\subsubsection{Decontamination Process}

The hot legs of the steam generators were decontaminated using grit. The $B$ steam generator was decontaminated in one pass, and the A steam generator was decontaminated in three passes, with resulting DRFs of about 2.25 and 3.5 , respectively. The entire decontamination operation took about 10 days, and the resultant exposure rates in the channel heads were $4.5 \mathrm{R} / \mathrm{hr}$ in the $\mathrm{B}$ steam generator and about $3.0 \mathrm{R} / \mathrm{hr}$ in the $A$ generator. Dose rates outside the manway were approximately 50 to $60 \mathrm{mR} / \mathrm{hr}$.

\subsubsection{Shielding}

In general, dose rates in the lower containment areas at Point Beach ranged from 5 to $8 \mathrm{mrem} / \mathrm{hr}$. On the work platform at the manway, dose rates were 50 to $60 \mathrm{mrem} / \mathrm{hr}$. Each platform was fitted with a lead shield wall to provide low-background (approximately $5-\mathrm{mrem} / \mathrm{hr}$ ) rest areas. For the most part, channel head workers made "half jumps" (waist high only) through the manway, and stay times were relatively short. Therefore, additional shielding was not used.

\subsubsection{Sleeving Process}

Tube surfaces were prepared for sleeve installation by honing. No substantial dose rate reduction was noted following the honing process.

Fifteen hundred sleeves were installed in each of the steam generators at the Point Beach facility. Most sleeves were inserted automatically and were expanded using a rolling technique. Mandrel loading was done manually; however, most positioning was performed remotely.

\subsection{SLEEVING AT R. E. GINNA}

The R. E. Ginna Generating Station began operating in March 1970 . From start-up in 1970 until 1974, the two-loop Ginna plant used phosphate as the secondary-water chemistry control agent. In 1974, the chemistry control was changed to an all-volatile system.

Except for tube degradation at the periphery of the hot leg in the $B$ steam generator, tube degradation at Ginna has been similar to that at other Westinghouse steam generators that began operation before the mid-1970s and used phosphate secondary-water chemistry control (NRC 1983). These problems have included wastage corrosion, stress corrosion cracking, and general intergranular attack, all of which have occurred in the interior of the tube bundle where sludge has accumulated on the tubesheet. 
Beginning in 1976, numerous tubes were plugged in the peripheral region of the $B$ steam generator on the hot-leg side. These tubes were plugged as a result of eddy current indications of defects initiated on the inside diameter or outside diameter of the tubes, or as a result of small leaks $(0.1 \mathrm{gal} / \mathrm{min})$. These defects occurred mainly in the wedge areas, where the support plates are attached to the shell of the steam generators, usually within the first 4 in. above the tubesheet. However, two tubes had defects approximately 24 in. above the bottom of the tubesheet.

Wastage and stress corrosion cracking above the tubesheet have been controlled since April 1977, following. conversion from phosphate to all-volatile chemistry control in December 1974. Since February 1979, intergranular attack and stress corrosion cracking have been detected near the center of the $B$ steam generator tube bundle in the narrow crevices between the tubes and tubesheet.

During a refueling outage in the spring of 1979 , the first indications of outside diameter intergranular attack of tubes in the tubesheet crevice region were discovered. In December 1979, 11 tubes were plugged in the B steam generator as a result of these indications; an additional 31 tubes were plugged in March 1980. The sleeving repair of tubes damaged by intergranular attack began in November 1980; when 5 tubes were sleeved in the B steam generator on a test basis. The sleeving test continued in 1981, with 16 additional sleeves installed in B steam generator in April of that year.

On January 25, 1982, one of the 3260 steam generator tubes in the B steam generator ruptured. After an investigation, it was concluded that the rupture was caused by wall thinning that may have resulted from contact wear with an adjacent plugged and severed tube (Nuclear Safety 1983). Based on the positive results of the sleeving tests, a major sleeving effort was initiated during the April-June 1983 outage at Ginna. In order to lower the radiation dose for workers, both steam generators were decontaminated. Seventy-nine tubes were sleeved during the outage. A major preventive-maintenance program for the steam generators including the eventual sleeving of approximately 2000 tubes per steam generator is planned for future outages.

\subsubsection{Shielding Preparations}

The only modifications made inside containment for the sleeving project consisted of setting up a control point, constructing a platform and tent at each steam generator manway, and setting up scaffolding to support shielding. Worker training, shielding installation, decontamination of the channel heads, and general-area decontamination preceded the sleeving activities.

\subsubsection{Training of Workers}

Because no extra contract laborers were brought in to the Ginna plant for the sleeving work, training in basic radiation protection, the use of protective clothing and respirators, and ALARA was minimized. However, all incoming personnel, including decontamination and sleeving vendor employees, received a 2 -day training course in general radiation protection. 
All steam generator workers received training in preparation for their specific tasks. Some of these tasks included the installation and removal of tube templates, the installation and maintenance of decontamination and sleeving equipment, the visual inspection of the tubes and sleeves, and the provision of support to personnel testing the sleeving seals. Two mockups of the Ginna steam generators were available for channel head training.

\subsubsection{Decontamination Process}

To lower the radiation dose for workers entering the steam generators for tube sleeving and related work, both steam generators were decontaminated using the London Nuclear CAN-DECON\& chemical treatment system. This was the first steam generator decontamination performed at Ginna, with the exception of a dry-grit blast used in A steam generator in 1972 .

The CAN-DECON treatment used on the B steam generator was a five-step process consisting of alternating cycles of acidic dissolution and oxidizing treatments. A total of $20 \mathrm{~kg}$ of metallic oxide containing $38 \mathrm{Ci}$ (38\% ${ }^{58} \mathrm{Co}$, $47 \%{ }^{60} \mathrm{Co}$ ) was removed. The resulting effective decontamination factor (DF) within the channel head was about 6 , according to utility dosimeter readings. The vendor measured the effective DF at about 10 (Smee 1983). The residual field was mainly due to shine from the nozzles (which were not decontaminated) and the tubes (which were decontaminated to an estimated height of 1 to 2 feet.)

When the decontamination equipment was connected to the A steam generator and the channel head was pressurized and filled, a slow steady leak from the channel head was observed. The leak was eventually traced to a poor seal on one of the nozzle dams due to out-of-roundness of the nozzle. Despite numerous attempts to seat the dam, a good seal was never achieved. Nevertheless, a three-step decontamination was performed, and $4 \mathrm{~kg}$ of oxide containing $34 \mathrm{Ci}$ were removed. An effective DF of 3 was achieved.

\subsubsection{Sleeving Process}

Initial plans called for sleeving about 500 tubes--79 with indications of tube damage and the rest as a preventative measure. The first batch of tubes were cleaned and sleeved, sealed, and tested for adequacy of the seals. Testing of the upper brazed seals showed that the seals were not satisfactory. After much testing it was discovered that the tubes were not sealing properly during sleeve expansion because corrosion products had built up between the support plate and tubes, locking the tubes at the first support plate. This problem was overcome by a presleeving bulging of the tubes. Finding the cause of the problem and deciding upon an appropriate solution used up much of the time scheduled for sleeving.

Seventy-nine tubes were successfully sleeved during the outage. Twentynine of these were short, 22-in. tubesheet sleeves used to repair damage within the tubesheet. Four of the tubesheet sleeves were installed in steam

Trademark of London Nuclear Limited. 
generator $A$; the remaining 25 were installed in steam generator $B$. Fifty longer (28-in. and 36-in.) sleeves were installed in steam generator $B$. Installation of the remaining tubes was postponed pending a ruling from the NRC concerning preventative sleeving.

\subsubsection{Tube Cleaning/Honing}

The tubes were cleaned with a swab-hone assembly. The tubes that were to be sleeved with the standard-length sleeves were cleaned using an automated manipulator. The tubes that were to receive tubesheet sleeves were cleaned manually because the automated manipulator was not designed to handle the short-sleeve processes.

\subsubsection{Sleeve Installation}

The tubesheet sleeves were installed manually in both steam generators. The standard-length sleeves in the B steam generator were installed remotely. All sleeves were expanded at the upper and lower joints with explosives. The charges for the tubesheet sleeves in the A steam generator were set manually. In the B steam generator, a cartridge was inserted into each sleeve outside the steam generator and the sleeve/cartridge assembly was loaded onto the tooling elevator installed in the channel head. Computer-controlled tooling located the correct tube and inserted the assembly into the tube. This action was verified with a television camera, and the cartridge was then detonated.

The upper joints were then brazed. Initial problems with inadequate sealing of the sleeve to the tube were corrected by the further expansion of the sleeves near the braze point. Where possible, uitrasonic testing was performed to confirm the integrity of the brazes. An argon pressure test was performed on the tubes where the brazes were questionable or where ultrasonic testing could not be done. 


\subsection{ASSESSMENT OF OCCUPATIONAL DOSES}

One of the primary reasons for steam generator replacement or extensive sleeving is to reduce future downtime for inspection and maintenance associated with tube repair. Some of these major repair projects have incurred large occupational doses but are projected to reduce the total dose over the long term (Driscoll and Chin 1983). Careful planning and the use of techniques to reduce the radiation fields or reduce worker time in these fields further improve the overall dose savings. Experience gained by the utilities and vendors and the increasing use of remotely-operated equipment have contributed to the significant reduction of the occupational doses associated with repair activities.

Each plant that conducted repairs gave considerable attention to minimizing the outage time and keeping doses ALARA. Good health physics practices and specific dose reduction strategies contributed heavily to keeping the occupational doses low. These techniques also tended to save time and, therefore, money by reducing the numbers of workers needed to perform the tasks.

The utilities have monitored occupational exposures related to steam generator repairs with a variety of survey and continuous-monitoring instruments and with personnel dosimeters. Real-time computer tracking systems have become popular as a means of tracking each worker's dose and the dose accrued during the performance of each task.

\subsection{STRATEGIES FOR KEEPING DOSES ALARA}

Current limits on occupational radiation exposures at nuclear power plants ensure a relatively low risk to personnel. However, it is in the best interest of the personnel involved to keep exposure, thus risk, ALARA and to ensure that a risk is assumed only if a comparable benefit is achieved. This philosophy, the fulfillment of which should be a goal of all radiation protection programs, presupposes that no radiation exposure should be incurred without a positive net benefit, taking into account technological, economic, and societal factors.

A common basis is needed for comparing the cost of reducing radiation exposure with the benefit to the public and/or worker health and safety of having done so. If the benefit equals or exceeds the cost, then the practice in question should be implemented. However, the cost-benefit analysis must be reviewed to ensure that the recommendations reflect sound professional judgment. In addition, because each licensee has specific needs that are critical to its radiation protection program, no single set of specific and detailed criteria can be set down as a prescription for achieving ALARA goals and the resulting benefits.

Each licensee's ALARA program should be fully integrated into its radiation protection program. Achieving a successful radiation protection program requires that plant and corporate management and personnel at all levels be aware of and committed to ALARA principles and goals. 
The extent of management's commitment to ALARA principles may differ among power plants, but all utilities have instituted ALARA programs to help reduce occupational exposures associated with steam generator repairs. The most common elements of the dose reduction strategies include personnel training in radiation practices, the installation of lead shielding to reduce dose rates to personnel working in or near high-radiation fields, general-area or specificcomponent decontamination to reduce surface and airborne contamination, and the use of remote tooling where practicable to reduce the occupancy in highradiation fields. Many of these aspects of each site's ALARA program have been described in the sections on repair processes. Some additional dose reduction strategies and those previously mentioned but worth further discussion are outlined below, along with developments in remote tooling and robotics.

\subsubsection{Surry Unit 1}

One of the methods used to help keep occupational doses ALARA during steam generator repairs was the use of work packages that divided activities into discrete tasks. The work packages facilitated the evaluation and review of work efforts and were a mechanism for improving the procedures and working conditions described. In addition, radiation work permits (RWPS) were used with individual sign-in to ensure that each worker was familiar with the specific radiological hazards that would be encountered and with the proper protective measures required during the work.

Another effective ALARA technique was the use of large contamination control envelopes, rather than small tents, around each cutting area. The steam generator cubicles, for example, were sealed with Herculite and used to form large containment areas in which workers wore respiratory-protection devices when required. The workers outside were able to work with greater efficiency because in most cases they were not required to wear respirators.

The use of temporary shielding became a very effective ALARA technique at Unit 1 due to changes in the shielding design package. Pipe ends were shielded by piling bags containing lead beads inside the pipe and covering the outside of the pipe with lead blankets. The use of lead curtains and other lead shielding during the removal and installation of miscellaneous piping in the steam generator reduced doses by a factor of 5 and led to an estimated occupational dose savings of 56 man-rem. The use of lead shielding during the cutting and removal of RCS piping resulted in a dose reduction factor of 6 and an estimated dose savings of 1170 man-rem. The overall dose savings attributed to the use of temporary lead shielding was 1611 man-rem. The dose incurred during the installation and removal of that shielding was 64 man-rem.

The water shielding resulting from filling the secondary side of the steam generator reduced dose rates in work areas above the steam generator channel head by a factor of 10 . An estimated occupational dose savings of 207 man-rem resulted from the use of water shielding (VEPCO 1980) during the performance of the following tasks: the removal of insulation around the upper she11, the mainstream piping, and the feedwater piping; the cutting and 
removal of the steam generator upper shell; the cutting of the mainstream and feedwater pipes; the removal of the steam generator instrumentation; and the removal of the blowdown piping.

Additional dose saving techniques included shielding the cab of the polar crane, using plasma arc cutting equipment rather than an oxyacetylene torch to cut the RCP, and removing and disposing of the highly contaminated valve packing before refurbishing pipe valves.

\subsubsection{Turkey Point Units 3 and 4}

The use of temporary shielding reduced dose rates in high-traffic and work areas. The installation and removal of shielding resulted in doses of about 43 man-rem for Unit 3 and 15 man-rem for Unit 4 . The exact dose savings is not quantifiable, but it is suspected that the savings greatly exceeded the exposure cost. Experience gained in the installation of shielding in Unit 3 is at least partially credited with the lower dose for shielding installation in Unit 4.

Decontamination of the containment area, both initially and as an ongoing activity, was quite successful in controlling contamination and thereby reducing dose. The doses expended for Units 3 and 4 were 66 and 53 man-rem, respectively. As a technique for maintaining good radiological working conditions and increasing the comfort and productivity of workers who would otherwise require respiratory protection, intermittent decontamination was highly beneficial.

The extent and spread of airborne contamination were effectively minimized by using water-cooled concrete-cutting equipment to remove large sections of concrete and by using corrugated-metal control envelopes with filtered ventilation to isolate cutting and grinding operations from adjacent areas. The exact amount of dose savings and the reduction of contamination incidents are not known, but these techniques increased the ease of surveys and decontamination and reduced work delays.

Channel head decontamination and shielding were the most effective components of the dose reduction efforts at Turkey Point. The dose expended for decontamination was about 155 man-rem for Unit 3 and 91 man-rem for Unit 4. The general-area dose rates in the channel head, which were initially 8 to $13 \mathrm{R} / \mathrm{hr}$, were reduced to 0.6 to $1 \mathrm{R} / \mathrm{hr}$ following decontamination and to 0.05 to $0.2 \mathrm{R} / \mathrm{hr}$ following shielding installation. This reduction in dose rate was also responsible for saving dose from other tasks performed near the steam generator as well as inside the channel head. The estimated dose savings for Units 3 and 4 were approximately 4400 man-rem and 5450 man-rem, respectively. These and other dose savings are based on licensee estimates (FP\&L 1982, 1983).

Improvements in the cutting machinery used for the lower assembly cuts and the use of remotely operated flame-cutting equipment for divider plate cuts reduced the exposure time in Unit 4. The beveled machine cuts also reduced the doses associated with welding preparation repairs and welding by 56 man-rem. 
The installation of blanket-type insulation in Unit 4, rather than the mirror-type used in Unit 3, significantly decreased labor hours and saved about 82 man-rem.

Temporary shielding of the reactor head area was beneficial in lowering doses prior to and after the hot functional testing of the systems. The saving from this shielding was estimated to be 90 to 120 man-rem. The overall dose savings between Unit 3 and Unit 4 was about 6000 man-rem as estimated by the licensee.

Turkey Point used some of the vendors who had proven their capabilities during Surry's repair program, because experienced vendors work efficiently and tend to spend relatively little time in high-dose areas.

The use of roving health physics technicians was beneficial in improving worker protection and keeping a better control of activities in radiation zones.

Scale models were used during the preplanning stages to look for probable problem areas. Mockups of the work areas were helpful for planning and essential for training workers. The channel head mockup was especially important in allowing workers to practice welds in a very confined space and to reduce their channel head time to a minimum. Lists showing the up-to-theminute dose information for each worker were available for the channel head workers to check before each entrance to the channel head.

The careful planning and scheduling of activities was credited with reducing doses for specific activities, such as cutting the channel head divider plate, and for limiting the size of the work force in containment. Health physics personnel took an active part in the replacement operations from the early stages of planning to the daily briefings and reviews of activity schedules.

\subsubsection{San Onofre Unit 1}

The use of magnetite grit blasting to decontaminate the steam generator channel heads resulted in an average exposure reduction of $3.5 \mathrm{R} / \mathrm{hr}$, or $47 \%$. The total dose received by workers during channel head decontamination was 173 man-rem. In addition, a decontamination crew regularly decontaminated walkways, steam generator platforms, and tools and equipment from the steam generator. The dose received during this work was 7 man-rem.

Shielding was extensively used and has been previously described (pp.24-25). Closed-circuit television and audio-communication systems were installed between the work areas inside the containment and several monitoring stations outside. These systems provided health physicists, quality assurance personnel, control operators, project supervisors, and project managers with low-exposure surveillance stations. The systems reduced the exposure of health physics personnel 53\%, from an average exposure rate of $11 \mathrm{mR} / \mathrm{hr}$ before installation of the audio-visual systems to an average of $5 \mathrm{mR} / \mathrm{hr}$ after system installation. The average exposure rate for control operators and supervisors was reduced $28 \%$, from $12 \mathrm{mR} / \mathrm{hr}$ before system installation to $8 \mathrm{mR} / \mathrm{hr}$ after system installation. 
The training program used helped to reduce exposure by alerting workers to efficient work procedures and helping them avoid hot spots.

Administrative controls, including reviews of procedures by ALARA personnel and health physicists, were used in steam generator project briefings and planning meetings, and to develop a health physics program specifically for the steam generator repair project.

Health physics technicians were responsible for implementing improvements where minor deficiencies in ALARA techniques were found. Over 100 minor problems were identified, documented, and resolved. San Onofre's records indicate the apparent cause and the disposition of each. In addition to providing reports on specific deficiencies to the health physics supervisor for the project, technicians maintained an informal log of problems to assure tracking. Various forms were developed to document ALARA activities. Daily dose updates were summarized from computer data distributed to supervisors and health physicists and posted for workers.

\subsubsection{Point Beach Unit 2}

At Point Beach Unit 2, both steam generators were decontaminated using grit blasting. The resulting decrease in the dose rates in channel heads allowed more efficient use of the channel head work force and reduced the total number of workers needed to perform the sleeving.

The dose rates at the channel head work platform were 50 to $60 \mathrm{mrem} / \mathrm{hr}$. A shield wall was erected on the platform to provide an area where two people could stand until they were required to enter the channel head. Dose rates behind the wall were 5 to $9 \mathrm{mrem} / \mathrm{hr}$.

The entire lower area under the steam generators (at El. $10 \mathrm{ft}$ ) was enclosed with Herculite so that the outer area would remain uncontaminated and respiratory protection would not be required. The general dose rates at the $10-\mathrm{ft}$ level were 5 to $8 \mathrm{mrem} / \mathrm{hr}$. Contamination at the El. $10 \mathrm{ft}$ level was low. A tool decontamination area with its own air supply and filtration system was set up at El. $10 \mathrm{ft}$. Additionally, laydown areas at the El. $8 \mathrm{ft}$ level were roped off and contained only essential equipment.

Extensive use was made of remotely controlled closed-circuit television (CCTV). Approximately 20 CCTV cameras were positioned around the work and access areas. The CCTV monitors were located in the control trailer, at the access point (one set for sleeving vendor technicians and one set for health physics technicians), and in the controlled work area. The CCTV system was complemented by a direct-linked-headset communications system. The combined use of the CCTV and communications network provided constant positive contact with all personnel involved in the sleeving process.

Training for the channel head workers was designed to accurately simulate the work to be performed. The 12-hr/class training sessions were consistent with the hours for shift work at the plant. Radiation protection procedures and ALARA concepts were constantly reinforced, and at the conclusion of the training period, all personnel were totally familiar with the sleeving process 
and all equipment that might have to be used. Channel head workers who participated in the training indicated later that the training sessions were more difficult than the actual work.

Limiting the number of people in the containment access area and the controlled work area minimized worker exposures. At any given time, about eight people were at the access point: two technicians who observed the sleeving procedures on the TV monitors and were available to provide assistance as needed; two health physics technicians who observed and recorded channel head stay times in the manway; two health physics technicians who helped dress and undress personnel entering and leaving the controlled work area; and two channel head workers who were entering or leaving the work area. Within the controlled area, there were two channel head workers at the work platform and two health physics technicians at observation points. Occasionally, a third health physics technician helped the channel head workers ascend or descend from the work platform. All of the personnel in the work area were in constant communication with the control trailer and personnel at the access control point. Personnel who were not required at the access control point or in the work areas assembled in a staging area outside the reactor building.

The management for Point Beach Nuclear Plant has made a commitment to keep contamination of the facility to a minimum. As part of this commitment, all personnel (both plant or contractor) are responsible for contamination control at the work site and for final cleanup of the work area. As a result of this commitment and other plant policies, there are fewer plant and contractor staff members at Point Beach Nuclear Plant than at most other operating plants, and no plant decontamination staff is maintained. Because of the relatively small plant staff, most nonroutine maintenance and outage work is contracted. Point Beach or WEPCO staff oversee the contract work. The associated health physics coverage is provided by a sole-source contractor.

The sleeving outage at Point Beach Unit 2 was basically turned over to the vendor. A WEPCO special projects group, consisting of the sleevingproject administrator, two health physics coordinators, and two site coordinators, oversaw the work. About 210 contractor staff were associated with the activity at the site. At any given time, approximately 80 people were available for channel head work and 30 health physicists or technicians were available for surveillance. The average staffing level to cover two shifts on the sleeving project was about 330 people. The relatively small staff and the resulting comaraderie among staff members appear to have contributed to the quality of the work and its early completion.

\section{1 .5 R. E. Ginna}

The management commitment to the ALARA principle was a notable aspect of the ALARA program at Ginna. The plant superintendent, who is the ALARA chairman, conducted at least three ALARA committee meetings per month during sleeving operations. In addition, a full ALARA meeting was held for each task expected to result in more than 5 man-rem. 
The chemical decontamination of the steam generator channel heads was important in reducing worker doses in the $B$ steam generator. The effective DF was 4 to 6 , according to the utility. The problems encountered in decontaminating the $A$ steam generator, and the lower DF of 3 achieved, may have resulted in more dose than was saved by the decontamination process.

The workers performing steam generator work were virtually all RG\&E employees. The sleeving vendor provided technical assistance for tube sleeving and plugging, and the decontamination vendor performed the channel head decontamination. Contract channel head workers were not used. The utility believes this resulted in more effective training and lower total worker doses.

The training of workers prior to steam generator work contributed to keeping exposures ALARA. A mockup of the channel head has been used for training since 1975, and the workers perform realistic tasks on the mockup, dressed in the same type of clothing as is used in actual steam generators: This mockup training has led on several occasions to improvements in the design of tools and the planning of tasks. Estimates of worker radiation doses are also derived from the mockup work.

A small compartment constructed of a steel-tubing frame and lead blankets was provided for personnel who performed ultrasonic tests on the steam generator tubes.

A maintenance crew of three was assigned to the health physics staff to perform general area decontamination. Decontamination was also performed by regular maintenance crews as part of the ALARA plan to reduce surface contamination and eliminate the need (in most cases) for working in respirators.

The health physics staff was involved in the early stages of planning for the steam generator repair work. The phases of each job were broken down into minutes per task for dose estimating. Before the job was actually performed, an ALARA check-off sheet was used to ensure that ALARA aspects of the work had been considered. The check-off sheet was also helpful for post-task analysis.

Other ALARA techniques used during the steam generator repairs included the use of a special decontamination tent in containment, controlled ventilation of the steam generator and other work areas, and the use of remote television cameras with built-in lighting systems for surveillance of steam generator activities.

\subsubsection{Developments in Remote Tooling and Robotics}

An extremely significant factor in the reduction of doses to workers has been the use of increasingly sophisticated remote tooling. Vendors are making a concerted effort to respond to utilities' demands for tooling that will reduce outage times by providing faster operation, reduce costs by requiring less manpower, and reduce occupational doses from major repairs. Much of the current equipment used for steam generator repairs is technically adequate, but it must be made more automated and more rapid in order to reduce the doses 
and costs associated with its use. The following information was gathered from publications and from discussions with staff members of Westinghouse Electric Corp. and Babcock \& Wilcox Co.

The development of better plugs and specialty sleeve designs is continuing, although most of the developmental focus is on installation, inspection, and retrieval equipment. Some of the research and development efforts are intended for vendor ownership of equipment where services are sold. 0ther equipment is being developed for purchase by utilities.

Tooling for maintenance and repair activities inside channel heads has progressed significantly since early 1980. Although some operations continue to be manual, particularly when repairs are minor, remotely controlled, computer-operated manipulators are being relied on increasingly. $X-Y$ axis coordinate and $\mathrm{R}-\theta$ polar-coordinate manipulators are capable of locating tubes and using tools fixed to the manipulator. Some of the manipulators require the previous installation of a template so that tools can be positioned below the proper row and column. Others can be operated without the templates if they can be calibrated using two or three tubes marked on the tubesheet.

Most of the manipulators have required at least one channel head entry for installation and one for removal. Others also require entries following each type of operation (e.g., between sleeve cleaning and honing) or for each sleeve insertion. Some new models use elevator systems to complete many tasks without intermediate entries, and others can install over 20 sleeves without reentry, using a cartridge. Some of the manipulators still have to be installed manually, while others, more recently developed, can be put into position from the manway. At least one device, after installation on the manway cover, can position itself, suspending itself from the tubesheet (Westinghouse Electric Corp. (no date)).

In addition to developments that reduce or avoid channel head entries, multitask tools that can complete more tasks without tooling changes are being developed. These tools are important for reducing both doses and the downtime for repairs. They may have additional uses inside the channel heads for inspections and for repairing noncircular tube endings. At least one is a general-use robotic arm that may have a variety of high-exposure applications.

Al1 of the products mentioned so far are used in the primary side of the steam generator. Remotely controlled equipment is also being developed to inspect and retrieve foreign objects in the secondary side. Early identification and retrieval of loose objects in the secondary side may prevent tube damage.

Fiberoptics, profilometry, and ultrasonic inspections are being used to diagnose early signs of tube damage and to inspect sleeve seals. Their use, especially their remote use, is proving a big asset in preventive maintenance.

\subsection{TECHNIQUES FOR MONITORING EXPOSURES}

Each plant used its own instruments to monitor radiation fields, airborne activity, and surface contamination. Personnel dosimetry varied from film 
badges to $\mathrm{CaSO}_{4}$ and $\mathrm{LiF}$ thermoluminescence dosimeters. The badge dosimeters, which were read periodically, provided the official dose values. All sites used self-reading pocket dosimeters, which were read at least daily and provided the accrued quarterly dose until the TLD results were available. Some utilities kept track of the exposure data manually during the repair activities but most used real-time computer systems to track individual worker doses and the doses charged to each task. The five plants' monitoring systems are discussed below.

\subsubsection{Surry Unit 1}

Conventional survey equipment, including Cutie-Pies (CPs) and GeigerMueller (GM) detectors and occasionally a shielded probe, were used for worker protection. No beta-specific instruments were used in surveys, as beta radiation was not considered to be a limiting factor. Protective clothing was believed to be sufficient for protecting against beta exposure in the channel head and RCP. Thermoluminescence-dosimeter studies were run on these two components to determine the gamma and beta doses to workers in the area. Worker doses were measured using VEPCO's regular plant $\mathrm{CaSO}_{4}$ Teledyne dosimeters on the head, torso, upper leg, and wrist for certain steam generator tasks.

Decontamination prior to task work paid off well in reducing skin contamination. The work at Surry Unit 1 involved an average of less than one case of skin contamination a week. The few instances that did occur were largely due to the improper removal of protective clothing. Skin contamination was removed by one or two washings. There were no cases of significant radionuclide uptake.

\subsubsection{Turkey Point Units 3 and 4}

Harshaw LiF two-chip (TLD 600 and 700) dosimeters and self-reading pocket dosimeters were used to monitor personnel exposures at Turkey Point. Pocket dosimeter readings were used as input to a computerized system for tracking real-time exposure histories. This system evaluated each worker's exposure before the worker entered the controlled area and was immediately updated when the worker left the controlled area. It was useful in identifying workers whose exposure was nearing the administrative dose limit. Two pocket dosimeters were used for certain high-exposure tasks in containment, and if the readings differed, the higher exposure was recorded. Additional dosimetric devices were worn as necessary when the worker might be exposed to potentially complex radiation fields.

Continuous (fixed-filter) air monitors were located in containment and would sound an alarm, if the airborne activity exceeded $10^{-9} \mu \mathrm{Ci} / \mathrm{cc}$. These monitors also provided a continuous indication of airborne activity.

While it was assumed that protective clothing attenuates most beta exposure and that gamma from ${ }^{60} \mathrm{Co}$ is the limiting exposure factor, FP\&L did monitor betas with Model RO-2A ion chambers and TLDS. An Eberline 10:1 shielded probe was also used to measure directional sources. 


\subsubsection{San Onofre Unit 1}

When the San Onofre sleeving operations began, the health physics department was short of survey equipment and, because of a backlog of equipment orders resulting from the TMI incident, was unable to purchase high-quality equipment to meet immediate needs. Thus, they had to rely on borrowed and obsolete equipment. New survey equipment was obtained as it became available. Initial surveys were made with a teletector survey instrument. included:

Routine surveys taken in the containment area during sleeving activities

- daily radiation and contamination surveys

- daily high-volume air samples on catwalks, in the channel head, and on platforms

- continuous low-volume air samples on platforms and near decontamination process equipment.

Chest film and self-reading pocket dosimeters with ranges of 0 to $200 \mathrm{mR}$ and 0 to $1 \mathrm{R}$ were carried by all workers associated with the steam generator project. In addition, workers entering the steam generator wore film on the head, Panasonic TLDs, and finger ring TLDs. Upon the completion of each day's work, all dosimeters except the chest film badge were returned for evaluation and re-use. Head and chest TLDs were read each day to verify or substantiate the results of the self-reading dosimeters. The results from this TLD system were compared with the results of the self-reading pocket dosimeters to determine how often film should be processed.

San Onofre health physics personnel conducted a number of tests to determine the maximum beta energy present in the channel heads. They concluded that the potential beta exposure for steam generator entrants was small relative to the gamma exposure. The utility reported that the incidence of personnel contamination was low and no significant internal depositions occurred.

\subsubsection{Point Beach Unit 2}

During sleeving activities, surveys were performed at a minimum of twice per shift or at the discretion of the health physics technician whenever changes in the work activity mandated it. A teletector was used for channel head surveys and an Eberline R0-2 was used for general-area surveys. Swipes taken from the channel head were analyzed isotopically and corrections for beta activity were determined.

The radiation dose to channel head workers was monitored using dosimeter packages placed on the head, the chest and, initially, the gonadal area. The package for the head contained a TLD and high- and low-range, self-reading pocket ionization chambers. The chest package contained high-, medium-, and low-range pocket ionization chambers. The gonadal area was monitored with a medium-range pocket ionization chamber. Monitoring of the gonads was discontinued after 30 channel head entries indicated that the gonadal dose would not 
be limiting. The official dose record, unless otherwise indicated, was based on the dose to the head as determined by the TLD results.

Although the airborne activity and contamination levels in the work area were low, channel head workers on the platform wore supplied-air masks, and other controlled-area workers wore full-face respirators with filtration. The licensee reported that personnel contamination was low and no significant internal depositions occurred.

\section{2 .5 R. E. Ginna}

Smear samples were counted in the laboratory with a BC-4 beta counter. Radiation Monitor Model RM-14s with smear counters were used in the containment and auxiliary buildings. Continuous air monitors were placed in working areas. Breathing-zone samples were taken in the channel head and in decontamination tents. Beta measurements were made using R0-7 and $\mathrm{RO}-2 \mathrm{~A}$ survey instruments. In addition, TLDs and film badges were placed on the steam generator manway cover to study beta response. Beta exposures were not significant relative to gamma exposures.

The plant dosimetry system was provided by TERA. Persons entering the steam generators wore film dosimeters and TLD badges in four locations (on the head, chest, thigh, ankle), in addition to a pencil dosimeter. The film dosimeter on the head was used to calculate the official dose. The utility reported that the incidence of personnel contamination was low and no significant internal deposition occurred.

\subsection{RADIATION DOSES TO WORKERS}

The NRC required periodic documentation of the occupational doses during the Surry and Turkey Point replacements but not during the sleeving at San Onofre, Point Beach, and Ginna. Since the sleeving repairs at Point Beach and Ginna have only recently been completed, the dose breakdown by task have been provided directly by plant personnel.

Direct comparison of the total doses incurred at the different sites is seldom justified because the sites used different techniques and vendors to accomplish repairs. The reduction in dose between units at the same plant can be more revealing, as the results of experience are usually reflected in the doses. However, an important trend in the occupational dose incurred during sleeving is demonstrated in the extreme dose reductions between the San Onofre and Point Beach sleevings. The same vendor was responsible for channel head decontamination and sleeving at both sites. The techniques and toolings were largely developed at San Onofre and improved prior to the Point Beach repairs. The experience gained at San Onofre and certain plant-specific factors were responsible for the very significant dose reduction at Point Beach. The dose at Ginna, on the other hand, cannot be directly compared with the dose at Point Beach even though their sleeving operations ran almost concurrently because the Ginna steam generators unexpectedly had tubes locked to the lower support plate, and extensive testing was required to identify the problem and determine a feasible solution. The sleeving technique used at Ginna also differed from that used at Point Beach. 
The doses associated with the steam generator repairs and the task breakdowns are discussed below for each site.

\subsubsection{Surry Unit 1}

The repair and replacement activities at the Surry Unit 1 steam generator resulted in approximately 1760 man-rem of radiation dose to workers. The cutting and installation of the RCP was the most significant task with regard to occupational dose. A summary of the labor used and the dose reported for Units 1 and 2 appears in Table 3.

Unit 2 work procedures and nonconformance reports were examined to determine ways to eliminate problems and reduce time and dose for the Unit 1 replacement activities. The strategies that worked well in Unit 2 were continued, and a number of changes to improve the Unit 1 replacement were instituted. These included:

- extensively decontaminating work surfaces

- adding shielding to the polar crane cab

- reducing the number of jib cranes to be installed (because of installation difficulties)

- improving plasma-arc cutting equipment

TABLE 3. Summary of Labor and Occupational Doses Associated with Steam Generator Replacement at Surry Units 1 and 2 (a)

\begin{tabular}{|c|c|c|c|c|}
\hline \multirow[b]{2}{*}{ Phase Description } & \multicolumn{2}{|c|}{$\begin{array}{c}\text { Labor } \\
\text { (man-hours) } \\
\end{array}$} & \multicolumn{2}{|c|}{$\begin{array}{c}\text { Occupational } \\
\text { Dose (man-rem) }\end{array}$} \\
\hline & Unit 2 & Unit 1 & Unit 2 & Unit 1 \\
\hline $\begin{array}{l}\text { Shutdown and Preparatory } \\
\text { Activities }\end{array}$ & 152,978 & 49,279 & 387.9 & 212.4 \\
\hline Removal Activities & 190,742 & 167,267 & 700.2 & 451.8 \\
\hline Installation Activities & 427,892 & 469,552 & 854.4 & 916.1 \\
\hline $\begin{array}{l}\text { Postinstallation and } \\
\text { Startup Activities }\end{array}$ & 96,372 & 105,092 & 193.0 & 170.5 \\
\hline $\begin{array}{l}\text { Steam Generator Storage } \\
\text { Activities }\end{array}$ & 3,659 & 937 & 5.1 & 8.1 \\
\hline Totals & 871,643 & 792,127 & $2,140.6$ & $1,758.9$ \\
\hline
\end{tabular}

(a) Source: VEPCO $1980,1981$. 
- installing new RCP rather than decontaminating, refurbishing, and reinstalling old RCP

- removing less RCP, which eliminated the need for one of the RCP welds

- sealing whole steam generator cubicles for cutting operations rather than using small tents and glove boxes

- removing and disposing of valve packing before refurbishing valves

- using videotapes of the Unit 2 replacement to familiarize workers with processes and containment surroundings.

It is difficult to directly compare the statistics for the two units because of the differences in task accounting. However, the decrease in dose of 382 man-rem, or nearly 20\%, and the decrease in labor of about 80,000 manhours, or nearly $10 \%$, are quite significant and reflect the improvements made and the experience gained in the replacement process.

An extensive task breakdown of the labor and occupational dose associated with the replacement activities at Units 1 and 2 is provided in Appendix $A$. Round-off error is responsible for the slight discrepancies from the information source (VEPCO 1980, 1981).

\subsubsection{Turkey Point Units 3 and 4}

The projected occupational dose for replacement activities at each of the Turkey Point units ranged from 1730 to 2480 man-rem. The actual dose for Unit 3 was 2151 man-rem (measured by self-reading pocket dosimeters), and that for Unit 4 was much lower, 1305 man-rem. Florida Power and Light Co. credits the lower dose from the Unit 4 activities to the following general experience and strategies (FP\&L 1983a):

- continuous critiquing of Unit 3 operations looking for ways to reduce time and exposure

- the higher state of readiness by plant and contract personnel

- greatly improved planning and scheduling

- Tess equipment and piping inteferences

- improved equipment operation and reliability, especially for the decontamination equipment

- higher worker productivity due largely to experience

- radiation fields $5 \%$ to $10 \%$ lower than those in Unit 3 . 
The reduction of total man-hours by about $20 \%$, or nearly 60,000 man-hours, and the reduction of occupational dose by $40 \%$, or about 850 man-rem, are significant and demonstrate the improvements made when the staff is experienced. Significant dose savings were achieved in every phase of Unit 4 activities (Table 4). The biggest reduction was in the miscellaneous category, which included cleanup, storage, and the many miscellaneous tasks preparatory to plant startup.

The installation phase was the most labor- and dose-intensive for both units. A breakdown of the tasks in each phase, showing labor and dose values for each unit, is presented in Appendix B. In a number of cases, the activities performed and the resulting doses were very similar for Units 3 and 4 . In several cases, Unit 3 had higher doses for certain tasks, but in a few cases involving the installation of scaffolding, the man-rem totals were much higher in Unit 4 than in Unit 3. In these last cases, it appears that the accounting of dose was responsible for the dissimilarities between the two units. However, a number of differences between the two units' repairs may explain some real variations in dose:

- To prevent a delay of repair operations, the Unit 3 cherry picker was installed close to the reactor vessel while the reactor head was on its stand rather than on the vessel. Better scheduling of the work in Unit 4 meant that this work did not have to be performed in high radiation fields.

TABLE 4. Summary of Labor and Occupational Doses Associated with Steam Generator Replacement at Turkey Point Units 3 and 4 (a)

\begin{tabular}{|c|c|c|c|c|}
\hline \multirow[b]{2}{*}{$\begin{array}{c}\text { Phase } \\
\text { Description }\end{array}$} & \multicolumn{2}{|c|}{ Unit 3} & \multicolumn{2}{|c|}{ Unit 4} \\
\hline & $\begin{array}{r}\text { Labor } \\
\text { (hours) } \\
\end{array}$ & $\begin{array}{c}\text { Occupationa } \\
\text { Dose } \\
\text { (man-rem) } \\
\end{array}$ & $\begin{array}{l}\text { Labor } \\
\text { (hours) }\end{array}$ & $\begin{array}{c}\text { Occupational } \\
\text { Dose } \\
\text { (man-rem) } \\
\end{array}$ \\
\hline $\begin{array}{l}\text { Preparatory } \\
\text { Activities }\end{array}$ & 31,787 & 247.94 & 49,422 & 229.99 \\
\hline $\begin{array}{l}\text { Removal } \\
\text { Activities }\end{array}$ & 61,252 & 552.48 & 54,457 & 395.62 \\
\hline $\begin{array}{l}\text { Installation } \\
\text { Activities }\end{array}$ & 135,373 & 899.58 & 132,539 & 562.60 \\
\hline Miscellaneous $^{(b)}$ & 91,081 & 451.83 & 24,005 & 116.61 \\
\hline Totals & 319,493 & $2,151.83$ & 260,423 & $1,304.82$ \\
\hline
\end{tabular}

(a) Source: FP\&L 1982, 1983a.

(b) Miscellaneous (preparations prior to startup, cleanup, storage, and post-installation). 
- Most of the scaffolding for the Unit 3 work was installed twice, first using a non-fire-retardant material, and then using the proper fireretardant material. This double installation resulted in additional dose.

- The steam generators from Unit 3 were placed in a temporary storage area outside containment until the storage facility was completed, then they were moved to the storage facility. This double handling resulted in additional dose.

- Two of three channel head cuts in Unit 3 were made using manual flame cutting. All three channel heads in Unit 4 were machine cut, which resulted in dose savings.

- Electromechanical problems with potentiometers caused poor flow characteristics with the decontamination "slurry" in Unit 3. The decontamination in Unit 4 went quite well and a higher DF was achieved. In addition, the decontamination waste tanks were put into casks inside containment in Unit 3 . The waste from Unit 4 was hard-piped to the radwaste building for treatment, and this system functioned we11.

- The remote spray arm was reprogrammed to improve the decontamination of the manways and environmental ledges in Unit 4 , as these were not sufficiently decontaminated in Unit 3.

- The Unit 4 channel head cuts were beveled so that most of the welding could be done from the outside of the steam generator.

Tables 4 and B.1 include a miscellaneous phase with significant doses. Tasks included in this phase are cleanup, storage, and preparations prior to startup. Nonmanual labor inside containment (by health physicists, quality control and engineering personnel, visitors, and primary contractor staff) are also included. A more detailed task breakdown was provided for Unit 4 than for Unit 3. Blanks appearing in the Unit 3 columns indicate hours or man-rem that are included with other task activities. The values have been rounded off and may not add up to the totals provided in the source information.

Records of the estimated occupational dose resulting from each of 13 major task categories were carefully kept on a real-time computer system. Data for this analysis were taken from daily (or more frequent) measurements of self-reading pocket dosimeters. The specific activities that comprised a task were identified on construction process sheets. These process sheets were reviewed by health physicists to incorporate ALARA recommendations and generate RWPs to track the dose for all activities in each task.

\subsubsection{San Onofre Unit 1}

The total occupational dose for the steam generator repair at San Onofre Unit 1 was 3493 man-rem. The average dose per sleeve for the 6900 sleeves was approximately 0.5 man-rem (Christopher 1983). A large portion of this dose can be attributed to the developmental nature of the operation and to equipment problems. Most individual doses were less than $1.5 \mathrm{rem}$. A few 
individuals received more than 2.0 rem during the project, and a few extremity doses exceeded 3.0 rem. The largest doses resulted from hands-on sleeving work (Table 3). Whole-body counts of workers indicated that each person's equivalent inhalation was much less than $40 \mathrm{MPC}$-hours in any 7 consecutive days. Throughout the project, only minor instances of personnel contamination occurred, and in all cases, onsite decontamination efforts were successful and follow-up whole-body counts indicated little, if any, uptake of radioactive material. The external doses reported for the steam generator project were somewhat higher than the actual doses because of the inherent overresponse of the film badges used for dosimetry. The reported doses are summarized in Table 5 .

One problem requiring a detailed dose assessment occurred when an aluminum nozzle cover fell down the cold leg of the A steam generator and had to be retrieved manually. To estimate the dose to a person entering the cold

TABLE 5. Summary of Occupational Doses Associated with Sleeving Activities at San Onofre Unit I (Allen and Dodson 1981)

\begin{tabular}{|c|c|}
\hline Phase Description & 1 Dos \\
\hline $\begin{array}{l}\text { Decontamination } \\
\text { Scheduled tasks } \\
\text { Unscheduled tasks }\end{array}$ & $\begin{array}{r}116 \\
57 \\
\end{array}$ \\
\hline Total & 173 \\
\hline $\begin{array}{l}\text { Tube Cleaning } \\
\text { Scheduled tasks } \\
\text { Unscheduled tasks }\end{array}$ & $\begin{array}{l}174 \\
105 \\
\end{array}$ \\
\hline Total & 279 \\
\hline $\begin{array}{l}\text { Sleeving } \\
\text { Scheduled tasks } \\
\text { Unscheduled tasks }\end{array}$ & $\begin{array}{r}2155 \\
621 \\
\end{array}$ \\
\hline Total & 2776 \\
\hline Radioactive Waste & 37 \\
\hline $\begin{array}{l}\text { Routine Maintenance } \\
\text { Housekeeping } \\
\text { Containment cleanup }\end{array}$ & $\begin{array}{r}61 \\
7 \\
\end{array}$ \\
\hline Total & 68 \\
\hline Special Sleeving and Inspection Tests & 118 \\
\hline Baseline Eddy Current Tests & 42 \\
\hline PROJECT TOTAL & 3493 \\
\hline
\end{tabular}


leg to remove the nozzle, a phantom was fitted with TLDs and lowered into the cold leg. Details are listed in the San Onofre Unit 1 final health physics report (Allen and Dodson 1981).

An administrative system of radiation exposure permits (REPs) was developed in an attempt to categorize exposure by work task. The REPs permitted access of up to eight worker categories and el iminated the need to process daily REPs. In addition, their use permitted running exposure totals to be tabulated and summarized by work location and job function.

\subsubsection{Point Beach Unit 2}

The total dose expended to perform the sleeving project was $524.6 \mathrm{rem}$. The average dose per sleeve installation based on the total outage dose was 0.175 man-rem. Dose by job task is delineated in the Table 6 . The total dose received was less than $50 \%$ of the pre-sleeving estimate. Doses were calculated from TLD to self-reading pocket dosimeter ratios.

For channel head workers who had a completed NRC Form 4 on file, doses were limited to $2500 \mathrm{mrem}$. For workers without a completed NRC Form 4, doses were limited to $1050 \mathrm{mrem}$, and female workers were limited to $300 \mathrm{mrem}$. Radiation doses to workers were recorded daily based upon timekeeping results and the daily readout of the pocket ionization chambers. The highest reading was recorded daily and used to update the dose records for each shift. Running dose records for the outage provided daily, weekly, and monthly dose totals. These totals were distributed to group heads and group supervisors and were

TABLE 6. Summary of Occupational Doses Associated with Sleeving Activities at Point Beach Unit 2

Job Task

Area and Equipment Setup

Equipment Decontamination

Health Physics Coverage

Channel Head Decontamination

Honing and Fiber Optics

Sleeve Insertion

Lower Sleeve Expansion

Upper Sleeve Expansion

Diatest

Eddy Current

Equipment Maintenance

Miscellaneous Activities

Total
Occupational

Dose (man-rem)

54.845

13.695

55.350

34.610

49.760

117.555

20.095

60.560

1.940

19.135

30.725

66.330

524.6 
posted at the health physics station at the access control point. Additionally, each shift report was reviewed by the plant's lead health physicist, the project health physics coordinator, and the contractor health physics supervisor. Prior to each channel head worker's entry into the control area, the health physics technician at the control point would check the results of the daily updates for that individual.

\subsubsection{R. E. Ginna}

The total dose for the recent Ginna steam generator repair project was about 471 man-rem. Approximately 130 man-rem of this dose was due to identifying that there was a problem with tubes locked at the first support plate; developing and trial-testing a method of brazing sleeves where tubes are locked in place; and sleeving the 79 tubes with indications of damage. Calculation of a man-rem-per-sleeve value from the total dose is not very meaningful for this particular case, as it does not reflect a mass production sleeving operaton. The occupational doses are summarized in Table 7.

In the $B$ steam generator, the following activities added to the man-rem requirements for the sleeving (RG\&E 1983): 1) a number of hardware modifications had to be made on the sleeving apparatus after it was placed in the channel head bowl; 2) a great deal of tube cleaning had to be performed, mostly by hand; and 3 ) the brazing process took longer than expected and had to be followed up by ultrasonic testing or testing with argon under pressure. Other high-exposure tasks in the B steam generator included the installation of nozzle dams (123 man-rem) and the decontamination of the channel head (160 man-rem). The nozzle dam installation in $A$ steam generator required

TABLE 7. Summary of Occupational Doses Associated with Sleeving Activities at R. E. Ginna

\section{Activity Description}

Staging of Equipment and

Setup of Control Points

Installation of Nozzle Covers

and Eddy Current Equipment,

and Examination of Eddy Current

Setup and Use of Water Lancing

Tube Sleeving

Installation of Nozzle Dam

Closeup of Primary System

Retrieval of Cam-Lock

Channel Head Decontamination

Other Support Activities

Total
Occupational Dose (man-rem) 
unforeseen grinding and welding from inside the channel head to make the nozzle dam fit and accounted for $70 \%$ of the total exposure associated with nozzle dam installation.

The channel head decontamination in the A steam generator accounted for $81 \%$ of the total exposure for the sleeving effort. Some of the problems were as follows:

1) The nozzle covers in their original condition would not seal. They had to be removed, machined, and reinstalled.

2) Six unplanned channel head entries were required, primarily to correct problems with the drain-back hole, which is drilled in the bottom center of the channel head casting and normally functions to drain the channel head into the straight bore of the nozzle.

3) A hose rupture during the second step of the decontamination sequence required the draining of the system.

4) Because this was the first time the CAN-DECON system had been used in an operating U.S. nuclear power plant, many modifications and adjustments had to be made as the decontamination proceeded.

An ALARA tracking number was assigned for every task anticipated as part of the outage, (e.g., channel head decontamination, nozzle dam installation, sleeving). A dose estimate for each task was then calculated based on previous experience, observations made during mockup training, and engineering information. As each task progressed, the workers' doses were obtained from pocket dosimeters and posted against the ALARA tracking number. The health physics personnel maintained dose records on a day-to-day basis and updated them at the end of each 12-hour shift. During frequent meetings of the ALARA committee, dose estimates were compared with the actual doses for each task. Where the doses were higher than the projections, means were sought to remedy the condition. At the end of the outage, a full ALARA review of each task was performed to identify items that could help lower personnel doses in future work. Although the ALARA tracking-number system worked well for major tasks, some routine work was charged to RWPs, causing some confusion in tracking exposures. A system of manually plotting out the intended sequence of tasks, called "Planalog," had been used in previous outages at Ginna. However, during the 1983 outage, a new computer-based system called "Project 2ه" was used, and there was some confusion before plant personnel learned its proper operation.

(3) Trademark of Project Software and Development, Inc. 


\subsection{MANAGEMENT OF RADIOACTIVE WASTE}

Because NRC required the periodic documentation of occupational dose and waste effluents throughout each replacement operation, the quantities of solid waste generated and of liquid and airborne wastes emitted as a result of the replacements are generally available. The utilities involved in sleeving programs were not required to publish interim reports and consequently have not yet released detailed information concerning the wastes generated during sleeving activities.

Considerable solid waste was generated during replacment activities, including large quantities of wood used for scaffolding; plastics from isolation tents, floor covering, and protective clothing; and piping, in addition to the retired steam generators. Solid waste from sleeving activities included large amounts of plastics, waste grit, and debris from channel head decontamination and tube cleaning.

In each cases, the liquid waste generated was largely from the laundry effluent. The activity in this waste was typically very low. At plants where the channel head was decontaminated, the large volume of liquid waste was separated from grit and debris and passed through ion exchange resins to remove most of the activity. At all plants, repair operations were preceded by a containment cleanup. This cleanup, intermittent decontamination activities, and the tube cleaning performed as part of the sleeving repairs, contributed to the liquid waste volumes.

Airborne emissions generally resulted from purging the containment building before beginning repairs and from cutting and grinding activities, particularly in the replacement operations.

The waste generated at each plant during steam generator repairs is discussed below.

\subsection{SURRY UNIT 1}

Managing the solid and liquid wastes from Units 1 and 2 during the Surry steam generator replacement program was a massive task that resulted in numerous problems. Initially at Unit 2, there was insufficient control over what materials were being taken into containment. Consequently, large quantities of reusable material, such as packing crates and many tools, ended up as solid waste. During the Unit 1 replacement, a technician was stationed at the containment entrance to prevent entry of unnecessary bulk. The solid waste was stored onsite for up to 2 years while waiting for packaging and shipment to the Barnwell or Hanford disposal sites. In-plant decontamination greatly reduced the amount of radioactive waste generated during the outage; however, increased manpower to sort the solid waste probably could have reduced the quantity of solid waste by up to $50 \%$. As it was, about $60 \%$ of the waste had contamination levels so low that no readings could be detected.

Because Barnwell accepts no wet waste, VEPCO had to handle wet waste separately. Mop heads were a large component of this type of waste. A drying 
process instituted initialiy was not very effective, so the mops were stabilized in cement and disposed of as dry waste. The quantity of laundry waste exceeded expectations due largely to the large number of workers. The excess was handled by an offsite contractor. Liquid waste was handled through the plant's liquid effluent system.

The quantitites of solid wastes generated and of liquid and gaseous effluents released from Units 1 and 2 are compared in Table 8.

The total volume of liquid released as a result of the Unit 1 replacement was 1.8 million gallons containing about $0.26 \mathrm{Ci}$. The largest contributor was the laundry waste water. Both the volume and the activity of the waste were slightly lower than those of the liquid waste released from Unit 2 . The distribution of isotopes in the liquid waste from the two units is shown in Table 9.

Airborne releases resulted primarily from the initial purging of containment after plant shutdown and the continuous ventilation during repair operations. The ventilation exhaust was filtered to minimize the release of particulates. The isotopic distributions of the gaseous effluents released from Units 1 and 2 are listed in Table 10.

TABLE 8. Comparison of Total Amounts of Solid, Liquid, and Gaseous Wastes from Replacement Activities at Surry Units 1 and 2 (VEPC0 1980, 1981)

\begin{tabular}{|c|c|c|}
\hline \multirow[b]{2}{*}{ Type of Waste } & \multicolumn{2}{|c|}{ Volume Generated } \\
\hline & Unit 2 & Unit 1 \\
\hline \multirow[t]{2}{*}{ Solid } & $57,790 \mathrm{ft}^{3}$ & $67,580 \mathrm{ft}^{3}$ \\
\hline & $63.6 \mathrm{Ci}$ & $45.0 \mathrm{Ci}$ \\
\hline \multirow[t]{2}{*}{ Liquid } & $3.0 \times 10^{6} \mathrm{gal}$ & $1.8 \times 10^{6} \mathrm{gal}$ \\
\hline & $0.519 \mathrm{Ci}$ & $0.259 \mathrm{Ci}$ \\
\hline \multicolumn{3}{|l|}{ Gaseous } \\
\hline Noble gases & $101.3 \mathrm{Ci}$ & $510 \mathrm{Ci}$ \\
\hline Iodine & $6.88 \times 10^{-6} \mathrm{Ci}$ & $3.27 \times 10^{-3}$ \\
\hline Particulates & $1.32 \times 10^{-3} \mathrm{Ci}$ & $2.70 \times 10^{-3}$ \\
\hline Tritium & - & $4.18 \mathrm{Ci}$ \\
\hline
\end{tabular}


TABLE 9. Isotopic Distribution of Liquid Effluents Released from Surry Units 1 and 2 (VEPCO 1980, 1981)

\begin{tabular}{|c|c|c|}
\hline Isotope & $\begin{array}{l}\text { Unit } 2 \text {, Total Activity } \\
\text { Released (Ci) } \\
\end{array}$ & $\begin{array}{l}\text { Unit } 1 \text {, Total Activity } \\
\text { Released (Ci) }\end{array}$ \\
\hline $\begin{array}{c}55 \\
60 \mathrm{Fe} \\
68 \mathrm{Co} \\
53 \mathrm{Co} \\
63 \mathrm{Ni} \\
1377^{\mathrm{Cs}} \\
511^{\mathrm{Cs}} \\
134 \mathrm{Cr} \\
54 \mathrm{Cs} \\
133 \mathrm{Mn} \\
24 \mathrm{Xe} \\
135 \mathrm{Na} \\
131 \mathrm{Xe} \\
13 \\
\mathrm{~A} 11 \text { others }\end{array}$ & $\begin{array}{c}1.41 \times 10^{-1} \\
1.04 \times 10^{-1} \\
1.01 \times 10^{-1} \\
6.79 \times 10^{-2} \\
4.93 \times 10^{-2} \\
2.46 \times 10^{-2} \\
2.24 \times 10^{-2} \\
5.08 \times 10^{-3} \\
- \\
- \\
- \\
- \\
3.26 \times 10^{-3}\end{array}$ & $\begin{array}{l}3.65 \times 10^{-2} \\
6.88 \times 10^{-2} \\
2.68 \times 10^{-2} \\
5.17 \times 10^{-3} \\
5.10 \times 10^{-2} \\
3-- \\
3.27 \times 10^{-2} \\
3.66 \times 10^{-3} \\
2.01 \times 10^{-2} \\
7.66 \times 10^{-3} \\
2.59 \times 10^{-3} \\
2.36 \times 10^{-3} \\
1.59 \times 10^{-3}\end{array}$ \\
\hline & -1 & \\
\hline Total & $5.19 \times 10^{-1}$ & $2.59 \times 10^{1}$ \\
\hline
\end{tabular}

TABLE 10. Isotopic Distribution of Gaseous Effluents Released from Surry Units 1 and 2 (VEPCO 1980, 1981)

\begin{tabular}{|c|c|c|}
\hline $\begin{array}{l}\text { Airborne } \\
\text { Releases }\end{array}$ & $\begin{array}{l}\text { Unit 2, Total Activity } \\
\text { Released (Ci) }\end{array}$ & $\begin{array}{l}\text { Unit 1, Total Activity } \\
\text { Released (Ci) }\end{array}$ \\
\hline Voble Gases & & \\
\hline $\begin{array}{l}133 \mathrm{Xe} \\
135 \mathrm{Xe}_{\mathrm{Xe}}\end{array}$ & $\begin{array}{r}99.4 \\
1.9\end{array}$ & 496.6 \\
\hline Others & -- & 13.4 \\
\hline Total & 101.3 & 510.0 \\
\hline Iodines & & \\
\hline $131_{I}$ & $6.88 \times 10^{-6}$ & $3.20 \times 10^{-3}$ \\
\hline Others & - & $7.16 \times 10^{-5}$ \\
\hline Total & $6.88 \times 10^{-6}$ & $3.27 \times 10^{-3}$ \\
\hline Particulate & & \\
\hline${ }_{58}^{60} \mathrm{Co}$ & $7.00 \times 10^{-4}$ & $1.65 \times 10^{-3}$ \\
\hline $137 \mathrm{Co}$ & $3.01 \times 10^{-4}$ & $4.85 \times 10^{-4}$ \\
\hline $138^{C S}$ & $2.19 \times 10^{-4}$ & $\begin{array}{l}2.90 \times 10^{-4} \\
1.01 \times 10^{-4}\end{array}$ \\
\hline${ }_{54}^{51} \mathrm{Cr}$ & $\begin{array}{l}4.94 \times 10-5 \\
4.51 \times 10^{-5}\end{array}$ & $6.07 \times 10^{-5}$ \\
\hline $\begin{array}{l}{ }^{54} \mathrm{Mn} \\
\text { Others }\end{array}$ & $\begin{array}{r}8.37 \times 10^{-0} \\
- \\
\end{array}$ & $1.16 \times 10^{-4}$ \\
\hline Total & $1.32 \times 10^{-3}$ & $2.70 \times 10^{-3}$ \\
\hline
\end{tabular}




\subsection{TURKEY POINT UNITS 3 AND 4}

The quantity of solid waste generated during the replacement of the Turkey Point steam generators amounted to about $60,000 \mathrm{ft}^{3}$ (Table 11) and was $31 \%$ higher for Unit 3 and $52 \%$ higher for Unit 4 than was initially projected. The activity in the solid waste was estimated to be about $215 \mathrm{Ci}$. The FP\&L personnel believe that much of the quantity that exceeded the amounts estimated was from plant-wide operations unrelated to the replacement operations. The largest volume of low-level waste from the replacement activities was from compacted dry active waste, such as paper, insulation, and lagging materials.

Solid waste was handled in a number of ways. Some of it, such as scaffolding, was recovered after decontamination. The contamination on concrete rubble, which had been painted with a sealant, was chipped off to depths of $1 / 4$ to $1 / 2$ in. Core samples confirmed that the sealant had prevented further penetration. The uncontaminated rubble was segregated from the contaminated rubble and retained onsite. The contaminated rubble was placed in appropriate containers for disposal at an authorized disposal facility.

The methods used to reduce the waste volume included controlling materials entering contaminated areas, segregating contaminated from uncontaminated wastes, and compacting wastes, as well as decontaminating some materials. Yellow plastic clothing and other plastic waste was packaged into appropriate containers. Contaminated waste was sorted from uncontaminated waste. The contaminated waste was packaged in appropriate containers and shipped to a licensed burial facility for disposal. Dry waste was packaged in Herculite-covered, weatherproofed wooden boxes prior to disposal. A highly effective box compactor reduced the volume of all compactible waste. Large equipment was covered and stored in trailers until it could be processed for reuse or readied for disposal.

Low-level waste was shipped to Barnwell within the limits of the company's monthly allocation. Any excess was sent to the Hanford low-level-waste site.

As at Surry, the largest source of liquid effluents was laundry waste. The liquid waste was passed through a contractor's demineralizer system and discharged accordingly. The activity readings, predominantly from activated metals $\left({ }^{58} \mathrm{Co},{ }^{60} \mathrm{Co},{ }^{54} \mathrm{Mn}\right.$, and $\left.110 \mathrm{~m} \mathrm{Ag}\right)$, were well below effluent limits (Table 12). The total activity was only $14 \%$ of the anticipated activity (excluding tritium) and $25 \%$ of the anticipated tritium activity.

The lack of radioiodines and noble gases in airborne releases from Unit 3 and the small quantities of these constituents in the releases from Unit 4 are typical of reactors shut down for an extended period of time (Table 13). The quantity of particulates released was less than $19 \%$ of the estimated quantity. 
TABLE 11. Solid Low-Level Radioactive Waste Generated and Shipped from Turkey Point by May 16, 1983 (FP\&L 1982, 1983b) (predominantly $\left.{ }^{137} \mathrm{Cs},{ }^{60} \mathrm{Co},{ }^{58} \mathrm{Co}\right)$

Waste Form

Waste Generated

Compacted dry active waste

Noncompacted dry active waste

Resin and filter media

Channel head decontamination waste

Miscellaneous

Total

Waste Shipped Offsite
Unit 3

Volume $\left(\mathrm{ft}^{3}\right)$
Unit 4 Volume $\left(\mathrm{ft}^{3}\right)$

TABLE 12. Isotopic Distribution of Liquid Effluents Released During Steam Generator Replacement at Turkey Point Units 3 and 4

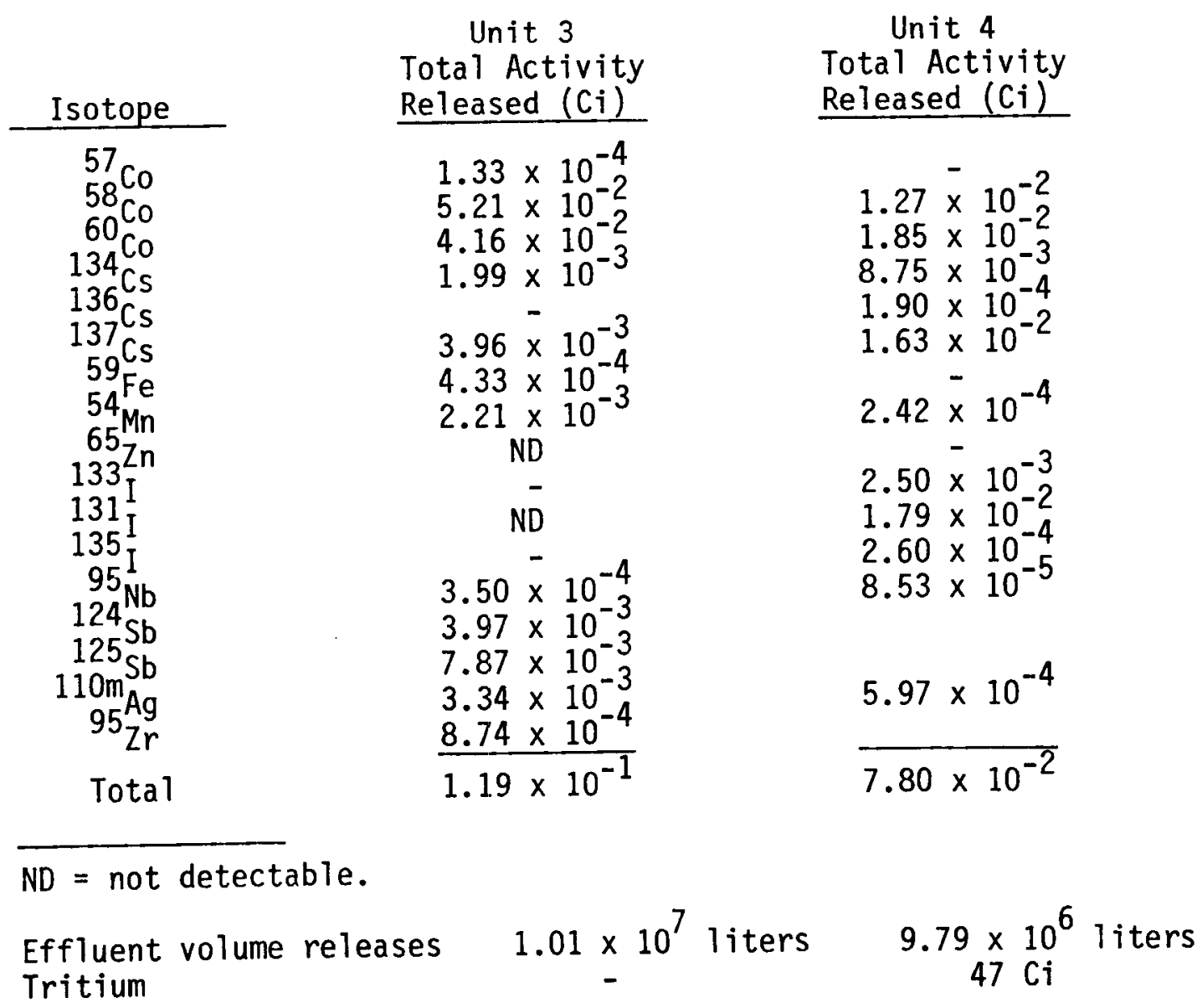


TABLE 13. Activity of Turkey Point Gaseous Effluents

(FP\&L 1982, 1983b)

\begin{tabular}{|c|c|c|}
\hline $\begin{array}{l}\text { Airborne } \\
\text { Releases }\end{array}$ & $\begin{array}{l}\text { Unit } 3 \\
\text { Total Activity } \\
\text { Released (Ci) } \\
\end{array}$ & $\begin{array}{r}\text { Unit } 4 \\
\text { Total Activity } \\
\text { Released (Ci) } \\
\end{array}$ \\
\hline $\begin{array}{c}\text { Noble gases } \\
41 \mathrm{Ae} \\
85 \mathrm{Kr} \\
85 \mathrm{~m}_{\mathrm{Kr}} \\
87 \mathrm{Kr} \\
88 \mathrm{Kr} \\
131 \mathrm{~m}_{\mathrm{Xe}} \\
133 \mathrm{Xe} \\
133 \mathrm{Xe} \\
135 \mathrm{Xe} \\
138 \mathrm{Xe} \\
\mathrm{Xe}\end{array}$ & $\begin{array}{r}- \\
- \\
- \\
\text { ND } \\
\text { ND } \\
- \\
\text { ND } \\
\text { ND } \\
\text { ND } \\
\text { ND }\end{array}$ & $\begin{array}{r}3.52 \times 10^{-1} \\
4.09 \times 10^{-1} \\
2.23 \times 10^{-1} \\
- \\
1.39 \times 10^{-1} \\
1.37 \times 10^{0} \\
8.62 \times 10^{2} \\
3.89 \times 10^{0} \\
6.59 \times 10^{0} \\
-\end{array}$ \\
\hline Total & - & $8.75 \times 10^{2}$ \\
\hline Tritium & - & $2.65 \times 10^{-2}$ \\
\hline $\begin{array}{c}\text { Halogens } \\
82 \\
131 \mathrm{Br} \\
133 \mathrm{I}\end{array}$ & $\begin{array}{l}\text { ND } \\
\mathrm{ND} \\
\end{array}$ & $\begin{array}{l}1.90 \times 10^{-4} \\
3.30 \times 10^{-2} \\
5.62 \times 10^{-3} \\
\end{array}$ \\
\hline Total & - & $3.88 \times 10^{-2}$ \\
\hline $\begin{array}{c}\text { Particulates } \\
131 \\
140 \mathrm{I} \\
141^{\mathrm{Ba}} \\
144 \mathrm{Ce} \\
57 \mathrm{Ce} \\
58 \mathrm{Co} \\
60 \mathrm{Co} \\
134 \mathrm{Co} \\
136 \mathrm{Cs} \\
137 \mathrm{Cs} \\
93 \mathrm{Cs} \\
59 \mathrm{Nb} \\
54 \mathrm{Fe} \\
65 \mathrm{Mn} \\
95 \mathrm{Zn} \\
140 \mathrm{Nb} \\
103 \mathrm{La} \\
51 \mathrm{Ru} \\
. \mathrm{Cr} \\
\text { Total }\end{array}$ & 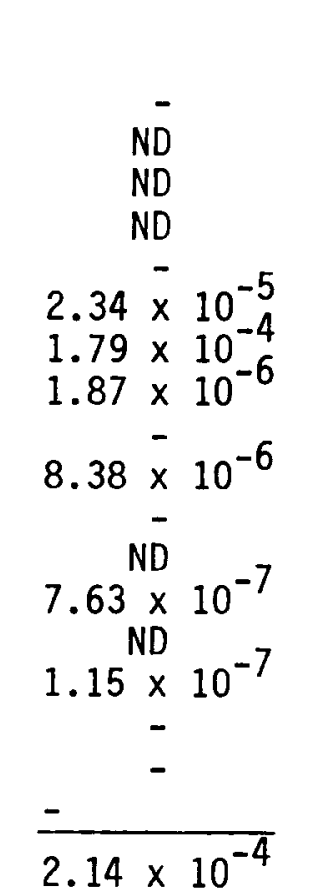 & $\begin{array}{r}1.04 \times 10^{-4} \\
2.00 \times 10^{-5} \\
- \\
- \\
3.50 \times 10^{-7} \\
3.79 \times 10^{-4} \\
2.82 \times 10^{-4} \\
1.13 \times 10^{-4} \\
3.54 \times 10^{-5} \\
2.32 \times 10^{-4} \\
3.31 \times 10^{-6} \\
-\overline{0} \\
2.50 \times 10^{-5} \\
- \\
- \\
1.40 \times 10^{-5} \\
3.80 \times 10^{-6} \\
1.20 \times 10^{-5} \\
1.22 \times 10^{-3}\end{array}$ \\
\hline
\end{tabular}




\subsection{SAN ONOFRE UNIT 1}

The health physics organization at San Onofre Unit 1 provided technicians to supplement the plant's radioactive-waste work force. These individuals, acting as shift radioactive-waste technicians, maintained close liaison with personnel in containment to ensure proper coordination of the movement of steam generator repair wastes to processing areas.

A summary of the waste and effluents generated during repair activities is listed in Table 14. No attempt was made to try to separate, from the total waste generated, those wastes and effluents directly due to decontamination and sleeving activities and those due to other station operations. A significant amount of compacted waste that was already onsite from previous outage activities is included here.

Airborne releases during the repair operations included $0.54 \mathrm{Ci}$ from beta and gamma emitters and $11.5 \mathrm{C} i$ from tritium. The beta activity in the liquid effluents totaled $3.8 \mathrm{Ci}$, with an additional $8.5 \mathrm{Ci}$ from tritium.

TABLE 14. Solid Waste Generated During Repair Outage at San Onofre, September 1980 Through June 1981

\begin{tabular}{|c|c|c|}
\hline Type of Waste & Activity (Ci) & Amount $\left(\mathrm{ft}^{3}\right)$ \\
\hline $\begin{array}{c}\text { Compacted Solid Waste } \\
3935 \text { drums }\end{array}$ & 110 & 30,202 \\
\hline $\begin{array}{l}\text { Other Solid Waste } \\
125 \text { boxes of low- } \\
\text { specific-activity } \\
\text { waste }\end{array}$ & 3.75 & 12,328 \\
\hline $\begin{array}{l}4 \text { liners of } \\
\text { solidified grit }\end{array}$ & 1.94 & 340 \\
\hline $\begin{array}{l}2 \text { drums of spent } \\
\text { hones }\end{array}$ & 0.433 & 12.7 \\
\hline Bag filters & 11.0 & 57.2 \\
\hline Hone filters & 45.0 & 142.5 \\
\hline Totals & 172.1 & 43,082 \\
\hline
\end{tabular}

\subsection{POINT BEACH UNIT 2}

The grit waste from the channel head decontamination operation at Point Beach Unit 2 was handled by a contractor. The grit was sluiced through a pipe from containment to the rad waste handling area and solidified within a liner. The solid honing waste was also handled and processed with this 
system. Four liners were used for disposal of the grit and honing waste. This resulted in approximately $310 \mathrm{ft}^{3}$ of waste. Few problems were encountered in the grit-handling process. A total dose of 5.38 man-rem exposure was received by the waste solidification contract personnel.

Fifteen 55-gallon drums were required to package and dispose of filters used to filter the grit. Radiation levels required that the drums be shipped inside a shipping cask.

Plant maintenance personnel processed and packaged miscellaneous waste generated during the sleeving project. The waste consisted of Herculite, plastics, and decontamination material. Virtually all waste was packaged in 55-gallon drums. A drum compactor was used to reduce waste volumes. The total volume of miscellaneous waste was approximately $4375 \mathrm{ft}^{3}$ or 580 drums.

Total volume of waste generated during the project, including the grit waste, grit filters, and miscellaneous waste, was approximately $4790 \mathrm{ft}^{3}$.

\subsection{R. E. GINNA}

Decontamination chemicals from the sleeving preparation at R. E. Ginna were processed through demineralizers. Waste resin from the decontamination system amounted to $400 \mathrm{ft}^{3}$. Solid waste at the plant was segregated according to whether the dose rate was above or below $5 \mathrm{mR} / \mathrm{hr}$. Solid waste of less than $5 \mathrm{mR} / \mathrm{hr}$ was then smeared and surveyed to determine whether it could be released as clean waste. Waste from the steam generator work was not segregated from waste from other plant activities. The total solid waste processed as a result of the outage was $5473 \mathrm{ft}^{3}$. 


\subsection{ACCUMULATED EXPERIENCE FOR FUTURE APPLICATION}

Utilities that have been involved with large-scale steam generator repairs, which have been first-of-a-kind operations, have encountered unforeseen difficulties and have found that the planning of the repairs was not always adequate. The experience base has increased considerably since the Surry Unit 2 replacement, and it continues to grow as new techniques and strategies are used to solve the problems encountered. Utilities planning major repairs will benefit from an awareness of the difficulties other utilities have encountered and the strategies that have been used to control occupational exposure.

A number of the lessons learned (e.g., the need for careful planning and scheduling) apply to all repairs. Others (e.g., the importance of the geometry of the channel head cut) are specific to certain types of repair or are dependent on the plant layout and design. Some general and specific recommendations that should be considered for future repairs are presented in this section.

\subsection{GENERAL APPLICATIONS}

Effective dose reduction strategies include the installation of lead shielding, secondary-side water shielding, containment decontamination, worker training, the use of proper protective clothing and respiratory-protection devices, and the use of administrative controls such as the ALARA review of work procedures and the issuance of RWPS.

- An effective training program is a necessity in ensuring worker protection and efficiency. Although considerable emphasis is being placed on perfecting remotely operated equipment so that channel head entries are seldom required, channel head workers are still needed. Training courses are needed to teach radiation protection procedures and ALARA concepts and to reinforce these procedures through the use of mockups simulating as closely as possible the conditions in which personnel will be working.

- The extensive use of audio-visual surveillance is extremely helpful to health physicists, QA personnel, contractors, and plant supervisors in coordinating and monitoring the progress of repair activities. It also helps limit the number of people in steam generator access areas and reduces the dose to these personnel.

- Similarly, remotely monitored survey equipment can be used to verify dose rates and may reduce the necessity of frequent radiation surveys.

- Posting of waiting areas in low-radiation fields, for use by workers waiting to do a task, reduces the time spent in higher-exposure areas. Benches should be provided so that workers will not be tempted to sit on bags of waste or potentially contaminated structures.

- Initial area cleanup in containment results in the removal of surface contamination and also reduces the concentration of airborne 
contaminants. Periodic decontamination of walkways, platforms, tools, and equipment is a beneficial practice that also reduces or el iminates the need for respiratory protection.

- Control of the quantity and types of material entering containment can keep the generation of contaminated solid waste to a minimum. The removal of shipping wrappers and crates outside of containment also helps prevent the unnecessary disposal of these items as low-level waste.

- Where possible, the use of free-standing shielding has numerous advantages over the direct placement of shielding. Particularly significant is the reduced time required for its setup and removal.

- Involving health physicists in the early planning stages and in daily briefings and reviews of activity schedules provides important opportunities to address strategies for dose reduction.

- One or more roving health physics technicians can help ensure that workers are properly dressed for the tasks and that procedures specified in RWPS are being followed.

- Real-time computer systems can be set up to show the cumulative dose, administrative limit, and quarterly dose remaining for each worker. Such computers are helpful in tracking the dose to the work force by task and in the early recognition of individuals approaching their quarterly limits.

\subsection{REPLACEMENT APPLICATIONS}

- Ventilated contamination-control envelopes very effectively isolate large areas to prevent airborne contamination from cutting and grinding activities from spreading throughout containment.

- The use of accurate as-built drawings of the inside of containment prevents unnecessary delays and time spent in high-exposure areas looking for cables and other equipment that is located elsewhere.

- There is an exposure tradeoff between decontaminating, refurbishing, and reinstalling $R C P$, and disposing of old pipe and installing new pipe.

- If the removal operation requires a channel head cut, a beveled girth cut reduces the time required in the channel head to weld the channel head to the new lower assembly.

- Protecting the tubesheet during welding activities for a channel head cut prevents smoke from penetrating into the tubes and eliminates the need to clean them later.

- If jib cranes will be needed for repair activities, installing them prior to the replacement outage can reduce delays during repair operations. 
- Disposing of valve-packing material before attempting to refurbish the primary-system valves is a simple means of reducing the exposure for this activity.

- The use of trailers for the locked temporary storage of contaminated equipment is helpful in segregating the equipment until time is available for decontamination or disposal.

\subsection{SLEEVING APPLICATIONS}

- The increasing use of remotely controlled tooling for sleeving activities has great potential for reducing doses. Although small projects may not benefit by reliable, sophisticated manipulators, large repair projects most certainly will.

The remote tooling currently available and that under development will help reduce doses associated with inspections and with tube plugging, sleeving, and cutting operations. The use of increasingly effective techniques for channel head decontamination will also play an important part in dose reduction where inspections and repairs must be made manually. During future repairs, especially where new technologies are used, the application of ALARA strategies and past experience will help keep doses low. 


\subsection{REFERENCES}

Allen, W. D., and J. S. Dodson. 1981. Final Health Physics Report, Southern Cal ifornia Edison Company, San Onofre Unit I. Steam Generator Repair Project, August 12, 1981.

Card, C. J. 1983. Final Draft. Steam Generator Decontamination: Methods and Past Applications. NUREG/CR-3503 (PNL-4209), U.S. Nuclear Regulatory Commission, Washington, D.C.

Christopher, T. A. 1983. "Advances in Steam Generator Repair and Replaceability Technology." Presented before the Atomic Industrial Forum, January 18, 1983, Westinghouse Electric Corporation.

Cooper, F. W. u.d. In-Place Retubing and Sleeving of Nuclear Steam Generator. Westinghouse Electric Corporation, Pittsburgh, Pennsylvania.

Driscol1, M. L., and P. K. W. Chin. 1983. "ALARA Considerations for Steam Generator Replacements." Presented at the 28th Annual Meeting of the Health Physics Society, June 19-23, 1983, Baltimore, Maryland.

Estes, R. R., E. A. Watjen and J. W. Gulaskey. 1979. "Retubing for On-Site Modification of Steam Generators." Nuclear Engineering International, February 1979, pp. 48-51.

Florida Power and Light Company (FP\&L). 1981. Steam Generator Repair Program for Turkey Point Unit 3: Radiological Progress Report (No. 2) for the Period August 23, 1981 Through November 3, 1981. Docket 50-250.

Florida Power and Light Company (FP\&L). 1982. Steam Generator Repair Program for Turkey Point Unit 3: Final Radiological Progress Report (No. 5) for the Period June 24, 1981 Through April 7, 1982. Docket 50-250.

Florida Power and Light Company (FP\&L). 1983a. Steam Generator Repair Program for Turkey Point Unit 4: Final Radiological Progress Report (No. 4) for the Period October 10, 1982 Through May 16, 1982. Docket 50-251.

Florida Power and Light Company (FP\&L). 1983b. Steam Generator Repair Program for Turkey Point Unit 4: Radiological Progress Report (No. 2) for the Period December 3, 1982 Through February 2, 1983.

Hoenes, G. R., M. A. Mueller and W. D. McCormack. 1980. Radiological Assessment of Steam Generator Removal and Replacement: Update and Revision. NUREG/CR-1595 (PNL-3454), U.S. Nuclear Regulatory Commission, Washington, D.C.

Malinowski, D. D. 1980. "San Onofre Unit I Steam Generator Tube Sleeving Independent Review Board Presentation, Introduction."

McKay, H. S. 1982. "Steam Generator Replacement at Surry Power Station." Nuclear Safety 23(1):72-84. 
Nuclear Safety. 1983. Steam Generator Tube Rupture at R. E. Ginna Nuclear Power Plant. Excerpted from NUREG-0909 report. 24(1)97-101.

Nucleonics Week. 1983. "Replacement of the Point Beach-1 Steam Generators," July 7, 1983, pp 3-4.

Rochester Gas and Electric Corporation. 1983. "Ginna Station ALARA Committee Meeting Minutes for Meeting \#8316, May 17, 1983, with Attachments A and B."

Sejvar, J., and P. H. Dawson. 1982. Evaluation of Abrasive Grit-HighPressure Water Decontamination. EPRI NP-2691. Prepared by Westinghouse Electric Corp. for Electric Power Research Institute.

Smee, J. L. 1983. "Decontamination of PWR Steam Generators by the CAN-DECONTM Process." London Nuclear News, Summer, 1983.

U.S. Nuclear Regulatory Commission (NRC). 1983. Safety Evaluation by the Office of Nuclear Reactor Regulation, R. E. Ginna Nuclear Power Plant. Non-Proprietary Version, Docket No. 50-244.

Virginia Electric and Power Company (VEPCO). 1978. Steam Generator Repair for the Surry Power Station Unit Numbers 1 and 2. NRC Docket Nos. 50-280 and 50-281, Washington, D.C.

Virginia Electric and Power Company (VEPCO). 1980. Steam Generator Repair Program for the Surry Power Station Unit No. 2: Final Report for the Period February 3, 1979 Through December 31, 1979. Dockets 50-280 and 50-281.

Virginia Electric and Power Company (VEPCO). 1981. Steam Generator Repair Program for the Surry Power Station Unit No. 1: Final Report for the Period September 14, 1980 Through June 30, 1981. Docket 50-280.

Westinghouse Electric Corporation. u.d. Remotely Operated Service Arm Brochure. Pittsburgh, Pennsylvania. 
APPENDIX A

OCCUPATIONAL DOSES BY TASK FOR STEAM GENERATOR REPLACEMENTS AT SURRY UNITS 1 AND 2

The occupational doses from the steam generator replacement program at Surry Unit 1 are broken down by phase and task and are listed in Table A.l with the doses from the Surry Unit 2 replacement. Blanks in the table indicate either differences in the replacement process or differences in the accounting of task exposure. 
TABLE A.1. Summary of Labor and Occupational Dose by Task for Steam Generator Replacement at Surry Units 1 and 2 (a)

\begin{tabular}{|c|c|c|c|c|}
\hline \multirow{2}{*}{ Task Description } & \multicolumn{2}{|c|}{ 1st Replacement-Unit 2} & \multicolumn{2}{|c|}{ 2nd Replacement-Unit 1} \\
\hline & $\begin{array}{l}\text { Labor } \\
\text { (man-hr) }\end{array}$ & $\begin{array}{c}\text { Dose } \\
\text { (man-rem) }\end{array}$ & $\begin{array}{c}\text { Labor } \\
\text { (man-hr) }\end{array}$ & $\begin{array}{c}\text { Dose } \\
\text { (man-rem) }\end{array}$ \\
\hline \multicolumn{5}{|c|}{ SHUTDOWN AND PREPARATORY ACTIVITIES } \\
\hline $\begin{array}{l}\text { Erecting Equipment Hatch } \\
\text { Temporary Enclosure }\end{array}$ & 1,073 & 0.46 & - & - \\
\hline $\begin{array}{l}\text { Preparation and Load- } \\
\text { Testing of Polar Crane }\end{array}$ & 2,757 & 2.88 & 463 & 1.29 \\
\hline Defueling and Fuel Storage & 3,437 & 22.12 & 2,863 & 23.50 \\
\hline $\begin{array}{l}\text { Installation of Reactor } \\
\text { Vessel Cavity Cover }\end{array}$ & 2,385 & 1.97 & 753 & 1.92 \\
\hline Installation of Jib Cranes & 13,405 & 14.82 & 3,492 & 5.48 \\
\hline $\begin{array}{l}\text { Disassembly of Manipulator } \\
\text { Crane }\end{array}$ & 1,501 & 2.42 & 629 & 1.53 \\
\hline $\begin{array}{l}\text { Installation of Steam } \\
\text { Generator Transport System }\end{array}$ & 7,527 & 13.10 & 3,948 & 6.95 \\
\hline $\begin{array}{l}\text { Removal of Biological } \\
\text { Shield Wall }\end{array}$ & 3,959 & 3.39 & 916 & 2.30 \\
\hline $\begin{array}{l}\text { Disassembly of Shroud } \\
\text { Cooling System }\end{array}$ & 918 & 1.52 & 601 & 1.23 \\
\hline $\begin{array}{l}\text { Cutting of Crane Wall at } \\
\text { Hatch Opening }\end{array}$ & 1,379 & 0.45 & 586 & 1.21 \\
\hline $\begin{array}{l}\text { Installation of Temporary } \\
\text { Ventilation System }\end{array}$ & 11,455 & 4.21 & 106 & 0.05 \\
\hline $\begin{array}{l}\text { Erecting of Temporary } \\
\text { Scaffolding }\end{array}$ & 14,559 & 74.4 & 4,846 & 14.79 \\
\hline $\begin{array}{l}\text { Installation of Temporary } \\
\text { Light and Power }\end{array}$ & 6,609 & 0.56 & 2,174 & 2.16 \\
\hline Cleanup and Decontamination & 17,216 & 22.6 & 14,920 & 58.0 \\
\hline Operation of Polar Crane & 1,368 & 2.32 & 198 & 0.14 \\
\hline
\end{tabular}

(a) Source: VEPCO 1980, 1981. 
TABLE A.1. Surry Units 1 and 2 (continued)

$\frac{\text { 1st Replacement-Unit 2 }}{\text { Labor }} \frac{\text { 2nd Replacement-Unit 1 }}{\text { Dose }}$ Task Description

SHUTDOWN AND PREPARATORY ACTIVITIES (continued)

Installation of Shielding

21,930

143.5

2,045

64.3

Installation of Service

Air System

2,491

0.67

627

2.20

Modification of Work

Platform

5,272

0.18

1,939

0.75

Removal of Reactor

Coolant Pump Motors

1,357

4.62

Protection of Containment Components

1,094

4.05

1,289

6.16

H.P., Q.A.

31,286

33.6

6,884

10.0

Unassigned Personnel

Categories Including

Project Supervision and

Administration

$\frac{\text { not reported }}{152,978} \frac{34.0}{387.9} \quad \frac{\text { not reported }}{49,279} \frac{8.47}{212.4}$

PHASE I PROJECT TOTAL

REMOVAL ACTIVITIES

Removal of Insulation

(lower shell, RCP)

2,026

13.8

1,647

14.0

Removal of Insulation

(upper shell, main steam

and feedwater piping)

80

1.36

959

5.35

Removal of Miscellaneous

Piping

5,424

59.3

1,288

13.90

Setup of Steam Generator

Girth Cut Equipment

224

0.23

90

0.21

Cutting and Removal of

Steam Generator Upper Shell

$\begin{array}{rrrr}5,079 & 11.2 & 5,529 & 9.17 \\ 20,235 & 214.1 & 7,181 & 76.7\end{array}$

Cutting of RCP

20,235

214.1

6.7 
TABLE A.1. Surry Units 1 and 2 (continued)

\begin{tabular}{|c|c|c|}
\hline & 1st Replacement-Unit 2 & 2nd Replacement-Unit 1 \\
\hline Task Description & $\begin{array}{cc}\text { Labor } & \text { Dose } \\
(\mathrm{man}-\mathrm{hr}) & \text { (man-rem) }\end{array}$ & $\begin{array}{cc}\text { Labor } & \text { Dose } \\
(\mathrm{man}-\mathrm{hr}) & \text { (man-rem) }\end{array}$ \\
\hline
\end{tabular}

REMOVAL ACTIVITIES (continued)

Cutting of Main Steam and

Feedwater Piping

$$
\begin{array}{llll}
2,838 & 1.13 & 1,399 & 2.39
\end{array}
$$

Disassembly of Steam

Generator Supports

$$
10,791
$$

49.0

6,988

55.1

Removal of Moisture

Separation Equipment

6,050

6.73

5,333

9.40

Refurbishment of Steam

Generator Upper Shell

21,756

19.82

12,900

10.9

Removal of Steam Generator

Level Instruments and

Blowdown Piping

2,311

7.67

1,462

6.39

Removal of Steam Generator Lower Shell

$$
3,859
$$

29.9

4,341

22.9

Erecting of Temporary

Scaffolding

11,969

46.5

13,611

40.9

Installation of Temporary

Lighting and Power

6,071

5.91

5,356

4.45

Cleanup and Decontamination

26,731

83.7

44,732

88.6

Operation of Polar Crane

1,308

1.04

2,365

2.4

Material Handling, Equipment Maintenance, and Miscellaneous Construction Activities

30,991

53.9

24,484

35.9

H.P., Q.A.

32,999

51.0

27,502

33.7

Unassigned Personnel?

Categories Including

Project Supervision

and Administration

PHASE II PROJECT TOTAL

not reported

190,742
44.0

700.2 not reported

167,267
19.4

451.8 
TABLE A.1. Surry Units 1 and 2 (continued)

Task Description

INSTALLATION ACTIVITIES

Installation of Steam Generator Lower Shell

Installation of RCP

Steam Generator Girth Weld

Installation of Main Steam

Piping

Installation of Feedwater

Piping

Installation of Blowdown and Miscellaneous Piping

Installation of Steam Generator Level Instruments

Installation of Insulation

Erecting of Temporary

Scaffolding

Installation of Temporary

Lighting and Power

Cleanup and Decontamination

Operation of Polar Crane

Material Handling, Equipment

Maintenance, and Mis-

cellaneous Construction

Activities

H.P., Q.A.

Unassigned Personnel

Categories Including

Project Supervision

and Administration

PHASE III PROJECT TOTAL 1st Replacement-Unit 2

Labor

(man-hr) (man-rem) 2nd Replacement-Unit 1

Labor Dose

(man-hr) (man-rem) 
TABLE A.1. Surry Units 1 and 2 (continued)

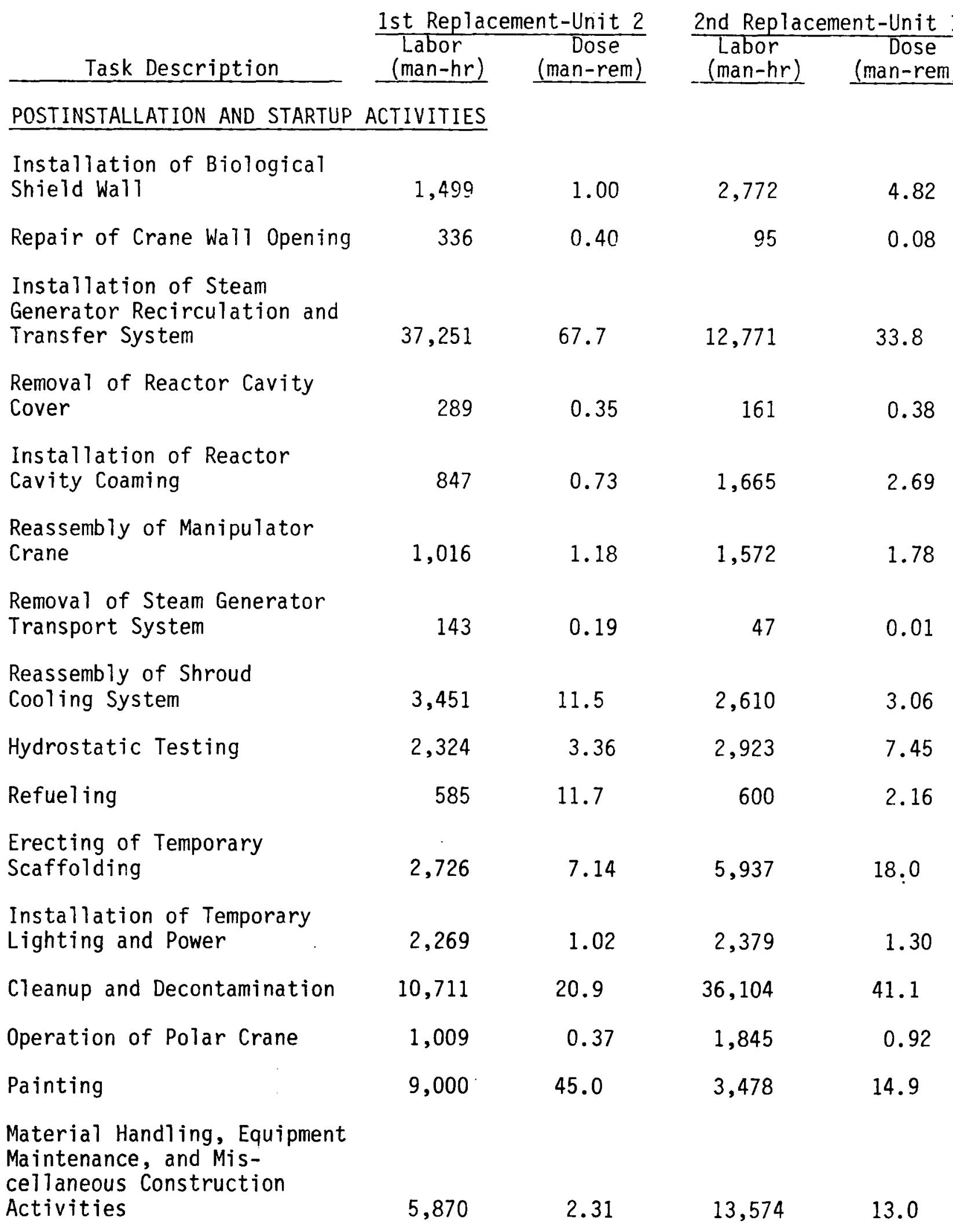


TABLE A.1. Surry Units 1 and 2 (continued)

\begin{tabular}{|c|c|c|c|c|}
\hline \multirow{2}{*}{ Task Description } & \multicolumn{2}{|c|}{ Ist Replacement-Unit 2} & \multicolumn{2}{|c|}{ 2nd Replacement-Unit 1} \\
\hline & $\begin{array}{l}\text { Labor } \\
\text { (man-hr) }\end{array}$ & $\begin{array}{c}\text { Dose } \\
\text { (man-rem) }\end{array}$ & $\begin{array}{l}\text { Labor } \\
\text { (man-hr) }\end{array}$ & $\begin{array}{c}\text { Dose } \\
\text { (man-rem) }\end{array}$ \\
\hline POSTINSTALLATION AND STARTL & ACTIVITIES (co & ontinued) & & \\
\hline H.P., Q.A. & 17,046 & 6.62 & 16,559 & 18.3 \\
\hline $\begin{array}{l}\text { Unassigned Personnel } \\
\text { Categories Including Pro- } \\
\text { ject Supervision and } \\
\text { Administration }\end{array}$ & not reported & 11.4 & not reported & 6.92 \\
\hline PHASE IV PROJECT TOTAL & 96,372 & 193.0 & 105,092 & 170.5 \\
\hline $\begin{array}{l}\text { Steam Generator Storage } \\
\text { Activities }\end{array}$ & 3,659 & 5.05 & 937 & 8.079 \\
\hline REPAIR PROJECT TOTALS & 871,643 & 2140.6 & 792,127 & 1758.8 \\
\hline
\end{tabular}




\section{APPENDIX B}

OCCUPATIONAL DOSES BY TASK FOR STEAM GENERATOR REPLACEMENTS AT TURKEY POINT UNITS 3 AND 4

The occupational doses from the steam generator replacement program at Turkey Point Units 3 and 4 are broken down by phase and task and are listed in Table B.1. Blanks in the table indicate either differences in the replacement process or differences in the accounting of task exposure. 
TABLE B.1. Summary of Labor and Occupational Dose by Task Breakdown for Steam Generator Replacement at Turkey Point Units 3 and 4 (a)

\begin{tabular}{|c|c|c|c|c|}
\hline Activity Description & $\begin{array}{l}\text { Labor } \\
\text { (man-hr) }\end{array}$ & $\begin{array}{c}\text { Dose } \\
\text { (man-rem) }\end{array}$ & $\begin{array}{c}\text { Labor } \\
\text { (man-hr) }\end{array}$ & $\begin{array}{c}\text { Dose } \\
\text { (man-rem) }\end{array}$ \\
\hline \multicolumn{5}{|l|}{ PREPARATORY ACTIVITIES } \\
\hline $\begin{array}{l}\text { Initial Decontamination } \\
\text { of Containment }\end{array}$ & 2,108 & 27.07 & 3,276 & 18.39 \\
\hline $\begin{array}{l}\text { Reactor Cavity } \\
\text { Decontamination and } \\
\text { Inspection }\end{array}$ & 373 & 5.58 & 162 & 1.51 \\
\hline $\begin{array}{l}\text { Reactor Cavity Liner } \\
\text { Plate Inspection }\end{array}$ & - & - & 300 & 6.04 \\
\hline $\begin{array}{l}\text { Installation of Steam } \\
\text { Generator Transfer Bridge }\end{array}$ & 1,473 & 7.80 & 147 & 0.29 \\
\hline $\begin{array}{l}\text { Removal of Emergency Con- } \\
\text { tainment Coolers, Control } \\
\text { Rod Drive Mechanism Coolers } \\
\text { and Fans, Manipulator } \\
\text { Crane; Rerating of Polar } \\
\text { Crane, and Load Testing }\end{array}$ & 5,157 & 7.80 & 1,774 & 4.55 \\
\hline $\begin{array}{l}\text { Disassembly and Storage } \\
\text { of Manipulator Crane }\end{array}$ & - & - & 123 & 0.91 \\
\hline $\begin{array}{l}\text { Installation of Cherry } \\
\text { Pickers }\end{array}$ & 2,990 & 17.88 & 266 & 1.35 \\
\hline Removal of RCP Motors & 386 & 2.43 & 397 & 2.59 \\
\hline $\begin{array}{l}\text { Disconnection/Removal of } \\
\text { Permanent Electrical } \\
\text { Equipment and Cables }\end{array}$ & 281 & 2.50 & 304 & 0.79 \\
\hline $\begin{array}{l}\text { Installation of Temporary } \\
\text { Power, Lighting and } \\
\text { Electrical Cables }\end{array}$ & 2,962 & 11.68 & 4,458 & 18.55 \\
\hline $\begin{array}{l}\text { Removal of Miscellaneous } \\
\text { Steel }\end{array}$ & 1,702 & 7.05 & 3,532 & 8.20 \\
\hline
\end{tabular}


TABLE B.1. Turkey Point Units 3 and 4 (continued)

$\begin{array}{llll}\frac{\text { Unit 3 }}{\text { Labor }} & \frac{\text { Unit 4 }}{\text { Activity Description }} & \begin{array}{c}\text { Labor } \\ \text { (man-hr) }\end{array} & \text { (man-rem) }\end{array}$

PREPARATORY ACTIVITIES (continued)

Installation of Temporary

Containments and/or

Ventilation Systems

1,740

12.62

1,013

2.92

Installation of Temporary

Shielding

1,388

31.05

1,193

11.27

Installation of Scaffolding at A11 Levels

1,895

9.95

5,203

34.19

Cutting and Removal of

Concrete

3,913

45.49

4,173

38.91

Project Nonmanua 1

Support

On-Going Decontamination

Activities

Containment Tool and

Weld Rod Room Support

Removal/Disposal of

Contaminated Materials

Crane Operation/

Maintenance

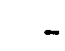

7,207

35.57

Miscellaneous

Activities

$\underline{5,419}$

59.04

7,560

11.21

TOTAL PHASE I

31,787

247.94

49,422

229.99

REMOVAL ACTIVITIES

Removal of Insulation

from Steam Generators

7,669

70.80

6,721

63.64

Removal of Feedwater

Piping from Steam

Generators

2,473

9.95

2,932

10.76 
TABLE B.1. Turkey Point Units 3 and 4 (continued)

\begin{tabular}{|c|c|c|}
\hline & Unit 3 & Unit 4 \\
\hline Activity Description & $\begin{array}{cc}\text { Labor } & \text { Dose } \\
\text { (man-hr) } & \text { (man-rem) }\end{array}$ & $\begin{array}{cc}\text { Labor } & \text { Dose } \\
(\text { man-hr) } & \text { (man-rem) }\end{array}$ \\
\hline
\end{tabular}

REMOVAL ACTIVITIES (continued)

Cutting of Steam Generators Upper Assemblies (U.A.) and Removal and Modification of U.A. Internals

13,379

60.02

683

$2.88^{*}$

Installation of Tube Bundle Shield Covers on Steam Generators 978

16.49

916

14.82

Cutting of Divider Plate and

Channel Head on Steam

Generators - Rig to 58-ft

Elevation

5,087

72.07

2,432

25.97

Rig/Lifting of Steam

Generators' Lower Assemblies to Cut/Remove Seismic Ring

142

0.72

221

3.59

Installation of Tubesheet

Shield Cover on Steam

Generators

527

10.10

1,124

16.39

Lifting of Steam

Generators' U.A., Inverting and Placement in Rack

2,143

11.79

1,575

7.74

Removal of Main Steam Piping

from Steam Generators

499

2.84

331

1.76

Installation of Laydown

Cribbing for Steam

Generators' 58-ft

Elevation

199

0.49

Conducting of Channel Head

Decontamination of Steam

Generators

6,503

155.12

5,547

90.71

Removal of Miscellaneous

Piping From Steam

Generator Cubicles

6,050

29.79

1,370

18.11

* Cut and removal only. 
TABLE B.1. Turkey Point Units 3 and 4 (continued)

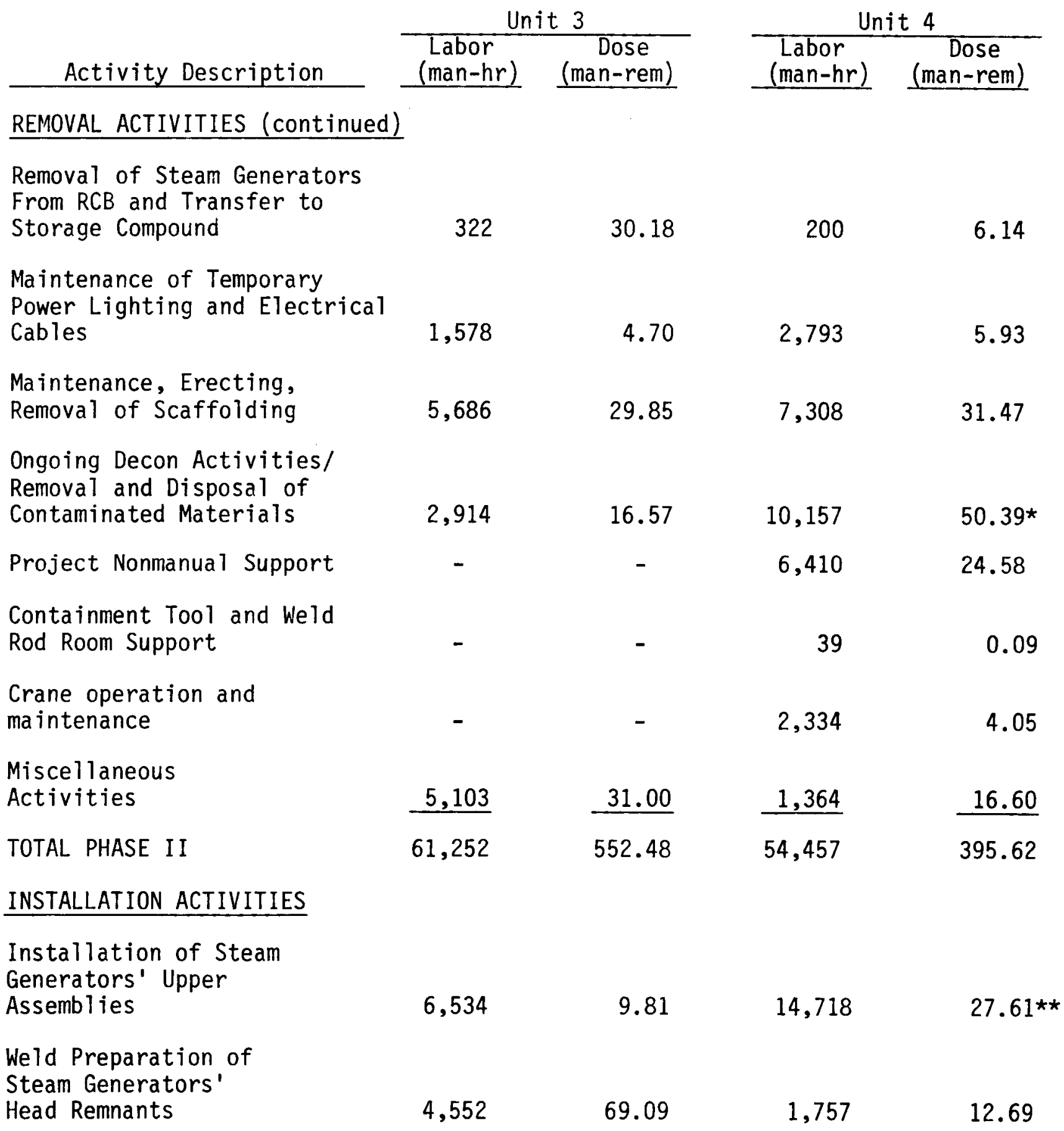

* Disposal (37.65 man-rem), decontamination (12.74 man-rem).

** Includes internals modifications. 
IABLE B.1. Turkey Point Units 3 and 4 (continued)

\begin{tabular}{|c|c|c|c|c|}
\hline \multirow{2}{*}{ Activity Description } & \multicolumn{2}{|c|}{ Unit 3} & \multicolumn{2}{|c|}{ Unit 4} \\
\hline & $\begin{array}{c}\text { Labor } \\
(\operatorname{man}-h r)\end{array}$ & $\begin{array}{c}\text { Dose } \\
\text { (man-rem) } \\
\end{array}$ & $\begin{array}{c}\text { Labor } \\
\text { (man-hr) }\end{array}$ & $\begin{array}{c}\text { Dose } \\
\text { (man-rem) }\end{array}$ \\
\hline \multicolumn{5}{|c|}{ INSTALLATION ACTIVITIES (continued) } \\
\hline $\begin{array}{l}\text { Installation and Welding } \\
\text { of Steam Generators' } \\
\text { Lower Assemblies }\end{array}$ & 35,381 & 382.64 & 27,143 & 213.77 \\
\hline $\begin{array}{l}\text { Installation of Steam } \\
\text { Generators' Main Steam } \\
\text { Piping }\end{array}$ & 2,068 & 4.16 & 996 & 2.28 \\
\hline $\begin{array}{l}\text { Installation of Steam } \\
\text { Generators' Feedwater } \\
\text { Piping }\end{array}$ & 4,892 & 15.71 & 1,013 & 1.89 \\
\hline $\begin{array}{l}\text { Welding of Steam } \\
\text { Generators' Divider } \\
\text { Plates }\end{array}$ & 5,479 & 119.86 & 2,760 & 58.46 \\
\hline $\begin{array}{l}\text { Installation of Insulation } \\
\text { on Steam Generators }\end{array}$ & 25,393 & 85.72 & 2,435 & 4.17 \\
\hline $\begin{array}{l}\text { Maintenance of Temporary } \\
\text { Power, Lighting and } \\
\text { Electrical Cables }\end{array}$ & 6,301 & 13.99 & 7,819 & 19.14 \\
\hline $\begin{array}{l}\text { Maintenance, Erecting, } \\
\text { Removal of Scaffolding }\end{array}$ & 9,794 & 31.81 & 17,625 & 58.58 \\
\hline $\begin{array}{l}\text { Ongoing Decon Activities/ } \\
\text { Removal/Disposal of } \\
\text { Contaminated Materials }\end{array}$ & 12,280 & 66.19 & 20,027 & 68.57 \\
\hline $\begin{array}{l}\text { Project Nonmanual } \\
\text { Support }\end{array}$ & - & - & 25,448 & 74.37 \\
\hline $\begin{array}{l}\text { Containment Tool and Weld } \\
\text { Rod Room Support }\end{array}$ & - & - & 458 & 0.84 \\
\hline $\begin{array}{l}\text { Crane Operation/ } \\
\text { Maintenance }\end{array}$ & - & - & 5,296 & 4.11 \\
\hline Miscellaneous Activities & 22,699 & $\underline{100.60}$ & 5,055 & 16.12 \\
\hline TOTAL PHASE III & 135,373 & 899.58 & 132,539 & 562.60 \\
\hline
\end{tabular}


TABLE B.1. Turkey Point Units 3 and 4 (continued)

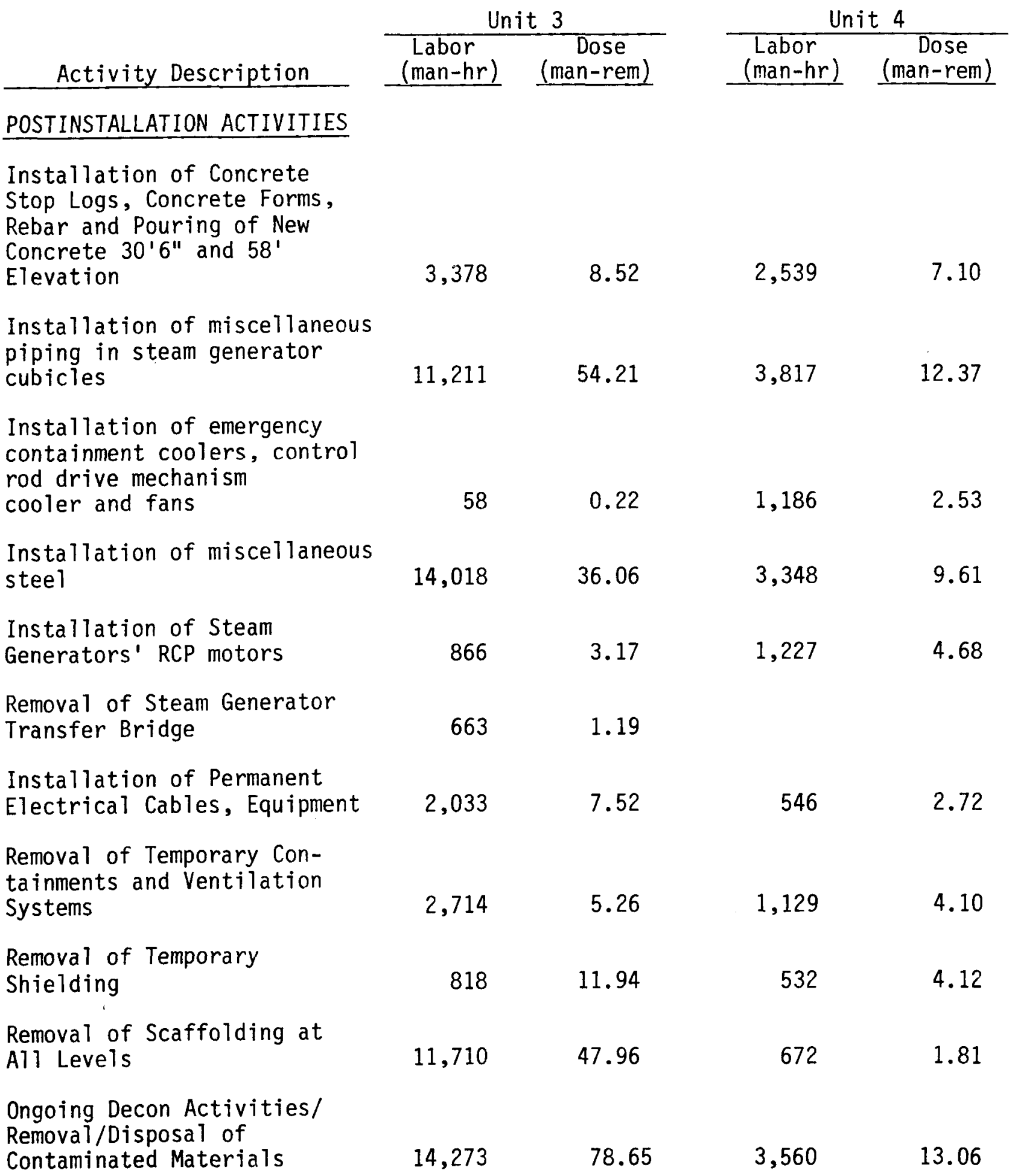


TABLE B.1. Turkey Point Units 3 and 4 (continued)

\begin{tabular}{|c|c|c|c|c|}
\hline \multirow{2}{*}{ Activity Description } & \multicolumn{2}{|c|}{ Unit 3} & \multicolumn{2}{|c|}{ Unit 4} \\
\hline & $\begin{array}{c}\text { Labor } \\
\text { (man-hr) }\end{array}$ & $\begin{array}{c}\text { Dose } \\
\text { (man-rem) }\end{array}$ & $\begin{array}{l}\text { Labor } \\
(\operatorname{man}-h r)\end{array}$ & $\begin{array}{c}\text { Dose } \\
\text { (man-rem) } \\
\end{array}$ \\
\hline \multicolumn{5}{|c|}{ POSTINSTALLATION ACTIVITIES (continued) } \\
\hline $\begin{array}{l}\text { Reactor Preparation/ } \\
\text { Hot Functional Testing }\end{array}$ & 1,265 & 53.21 & 850 & 30.94 \\
\hline $\begin{array}{l}\text { Tube Cleaning/Inspection } \\
\text { of Steam Generators }\end{array}$ & 1,290 & 23.83 & 302 & 8.31 \\
\hline $\begin{array}{l}\text { Installation of Manipulator } \\
\text { Crane }\end{array}$ & - & - & 484 & 1.63 \\
\hline $\begin{array}{l}\text { Steam Generator Secondary } \\
\text { Hydrostatic Testing }\end{array}$ & - & - & 281 & 0.59 \\
\hline $\begin{array}{l}\text { Removal of Secondary } \\
\text { Exhaust System }\end{array}$ & - & - & 252 & 1.75 \\
\hline Project Nonmanual Support & - & - & 1,534 & 6.69 \\
\hline $\begin{array}{l}\text { Containment Tool and Weld } \\
\text { Rod Room Support }\end{array}$ & - & - & 89 & 0.14 \\
\hline $\begin{array}{l}\text { Crane Operation and } \\
\text { Maintenance }\end{array}$ & - & - & 160 & 0.14 \\
\hline Miscellaneous Activities & 26,784 & 120.09 & 1,497 & 4.32 \\
\hline TOTAL PHASE IV & 91,081 & 451.83 & 24,005 & 116.61 \\
\hline REPAIR PROJECT TOTALS & 319,493 & $2,151.83$ & 260,423 & $1,304.82$ \\
\hline
\end{tabular}




\section{ACKNOWLEDGMENTS}

We would like to thank Florida Power and Light Company, Rochester Gas and Electric Company, Southern California Edison Company, Virginia Electric and Power Company, and Wisconsin Electric Power Company, along with Babcock \& Wi Tcox Company and Westinghouse Electric Corporation, for the information they have provided and for their reviews of this document. Our appreciation is also extended to Catherine J. Card for her initial coordination of the project and to Marianna Cross for word processing and Janet L. Baer for editorial support.

The efforts of the Nuclear Regulatory Commission, Division of Integrated System, are also appreciated, particularly those of R. J. Serbu, Program Manager. 


\section{DISTRIBUTION}

No. of

Copies

OFFSITE

R. J. Serbu

Division of Systems Integration

Mail Stop P-712

U.S. Nuclear Regulatory Commission Washington, DC 20555

U.S. Nuclear Regulatory Commission Division of Technical Information and Document Control

7920 Norfolk Avenue

Bethesda, MD 20014

Fatimah Afshar

Fluor Power Services, Inc.

200 West Monroe St.

Chicago, IL 60606

James Bates

Florida Power \& Light Co.

P.0. Box 529100

Miami, FL 33152

Jacob Celnik

Stone \& Webster Engineering Corp.

One Penn Plaza

250 West 34th Street

New York, NY 10119

Pat Conroy

Westinghouse Electric Corp.

P.0. Box 2728

Pittsburgh, PA 15230

Frank Cooper

Westinghouse Electric Corp.

P.0. Box 2728

Pittsburgh, PA 15230
No. of

Copies

Joe Danek

Florida Power \& Light Co.

P.0. Box 529100

Miami, FL 33152

Richard H. Danforth

224 Avenida Monterey \#3

San Clemente, CA 92672

John B. Dohring

Knolls Atomic Power Lab

Room 115, Bldg P-2

1 River Road

Schnectady, NY 12309

Duane Filkens

Robert E. Ginna Nuclear

Power Plant

1503 Lake Road

Ontario, NY 14519

Roger Gilchrist

1119 Saddle Way

Richland, WA 99352

Nancy Zacha Godlewski

Nuclear News

555 N. Kensington

LaGrange Park, IL 60525

Richard A. Govers

Babcock \& Wilcox

P.0. Box 1260

Lynchburg, VA 24505

J. E. Gutzwiller

Babcock \& Wilcox

P.0. Box 1260

Lynchburg, VA 24505

James L. Harrison

Systems Coordination Inc.

P.0. Box 2600

Crystal River, FL 32629 
No. of

Copies

Ernie N. Hayden

Westinghouse Electric Corp.

P.0. Box 2728

Pittsburgh, PA 15230

Doug Johnson

Point Beach Nuclear Plant

Wisconsin Electric Power Co.

Route 3, Box 48

Two Rivers, WI 54241

T. Will iam Keegan

Odetics Inc.

3049 SW 45th

Topeka, KA 66605

John P. Madison

Daniel Construction Co.

Daniel Centre

Greenville, SC 29602

H. Stephen McKay

Virginia Electric and Power Co.

P.0. Box 26666

Richmond, VA 23204

Dennis W. Murphy

REECo

3084 S. Highland

Las Vegas, NV 89114

Don Neeley

239 w. 5th Ave.

Collegeville, PA 19426
No. of

Copies

Steve Sarver

Virginia Electric and Power Co. Route 650, Highway 10

Surry, VA 23883

Tom E. Sliva

Babcock \& Wilcox

P.0. Box 1260

Lynchburg, VA 24505

Richard V. Warnock

San Onofre Generating Station

Southern California Edison Co. P.0. Box 128

San Clemente, CA 92672

ONSITE

50 Pacific Northwest Laboratory

C. J. Card

J. R. Divine

G. R. Hoenes

L. F. Munson

M. A. Parkhurst (37)

L. A. Rathbun

W. D. Reece

Technical Information (5)

Publishing Coordination (2) 


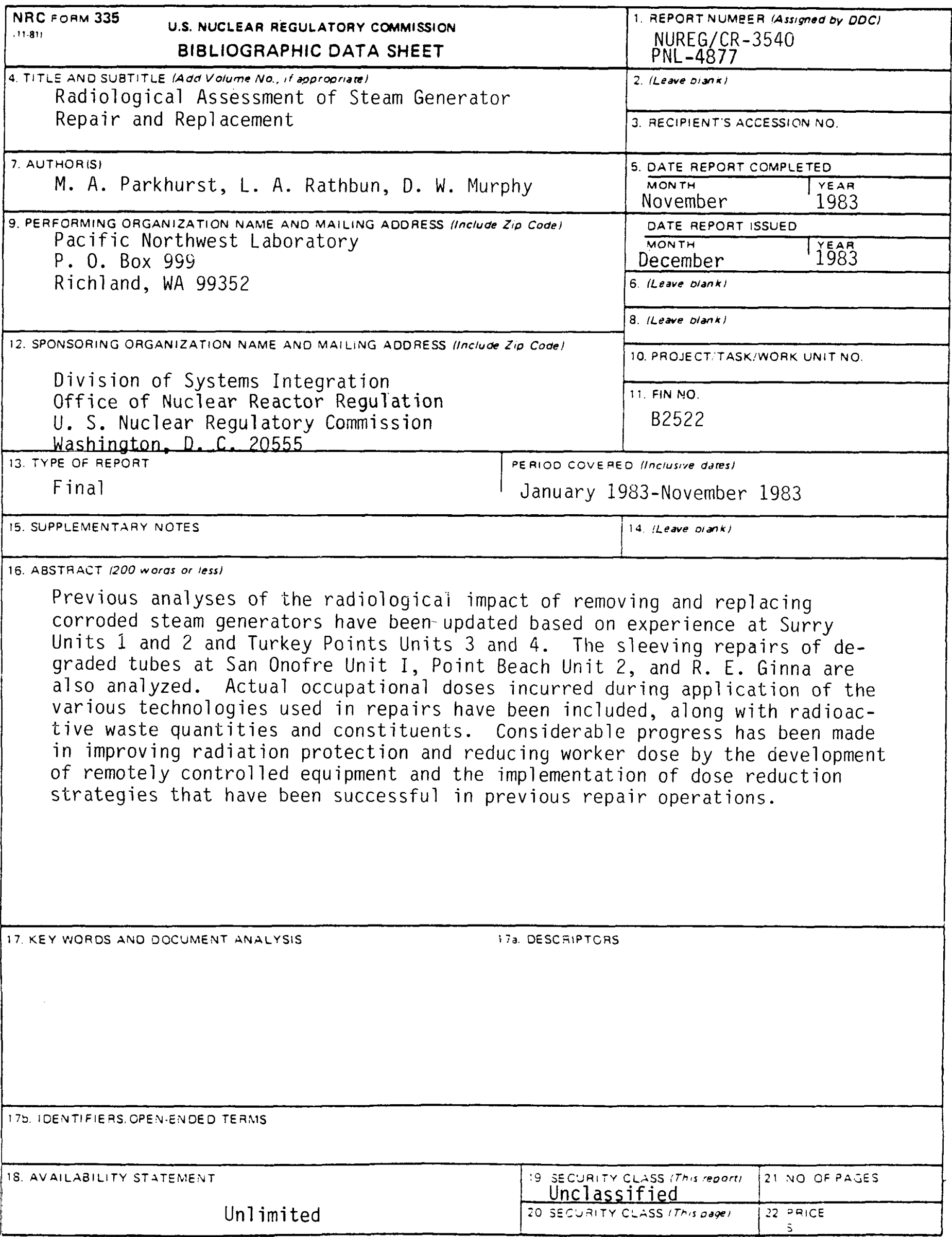

